\title{
Sedimentary Exhalative (Sedex) Zinc-Lead-Silver Deposit Model
}

Chapter $\mathrm{N}$ of Mineral Deposit Models for Resource Assessment
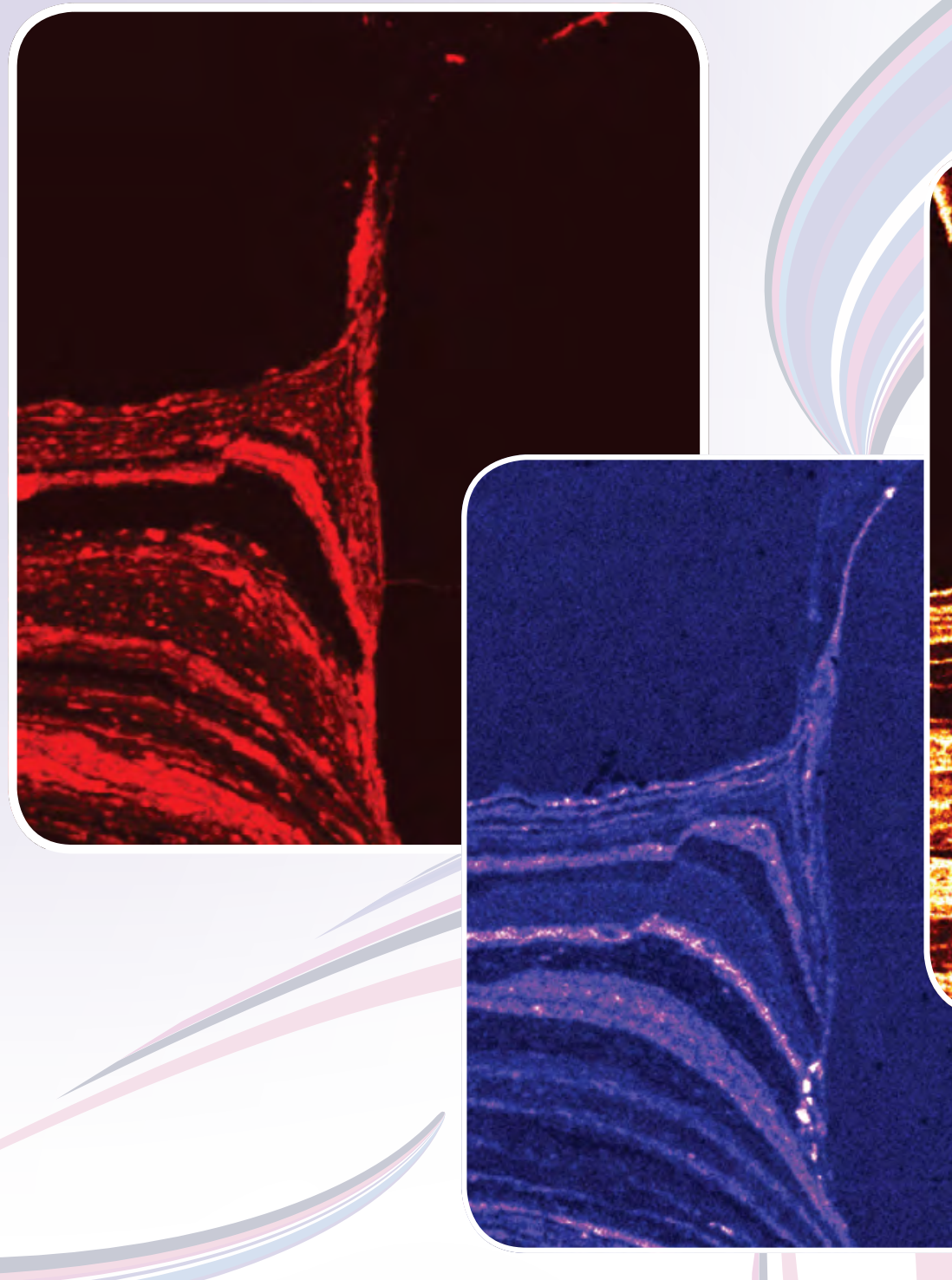

Scientific Investigations Report 2010-5070-N

U.S. Department of the Interior U.S. Geological Survey 

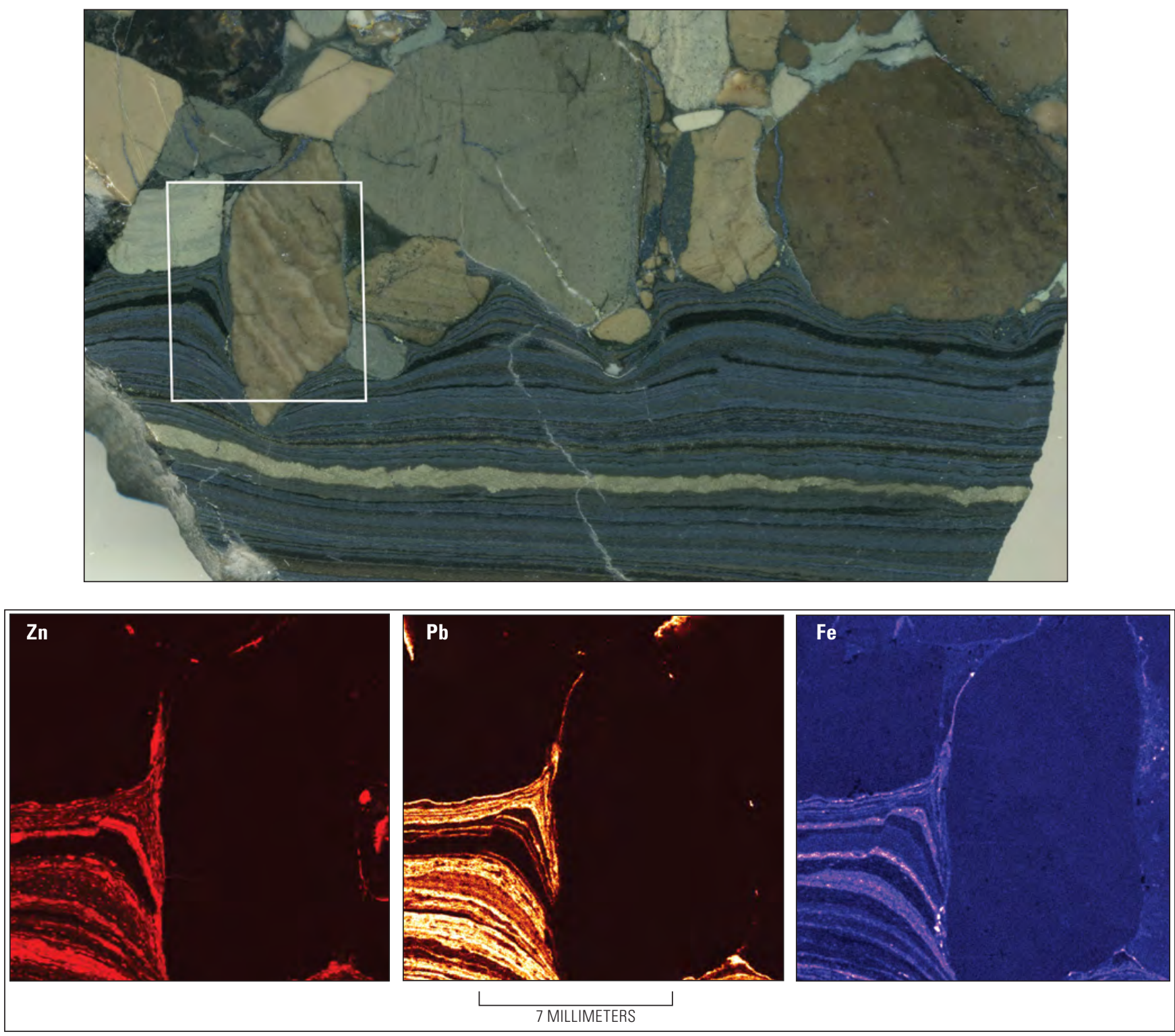

Cover. Polymictic sedimentary conglomerate overlying rhythmically laminated high-grade sphalerite and galena ore from the I 3/4 horizon in McArthur River (HYC) deposit, Australia. Inset shows scanning micro x-ray fluorescence (XRF) map of zinc (Zn), lead $(\mathrm{Pb})$, and iron (Fe) concentrations. Deformation and partial truncation of fine, chemically graded laminae at contact with conglomeratic base of the overlying turbidite and intralaminar deformation together indicate deposition and modification through sea-floor processes, suggesting ore was deposited syndepositionally as a chemical sediment on the sea floor. 


\section{Sedimentary Exhalative (Sedex) Zinc-Lead-Silver Deposit Model}

By Poul Emsbo, Robert R. Seal, George N. Breit, Sharon F. Diehl, and Anjana K. Shah

Chapter $\mathrm{N}$ of

Mineral Deposit Models for Resource Assessment

Scientific Investigations Report 2010-5070-N 


\title{
U.S. Department of the Interior SALLY JEWELL, Secretary
}

\section{U.S. Geological Survey Suzette M. Kimball, Director}

\author{
U.S. Geological Survey, Reston, Virginia: 2016
}

For more information on the USGS - the Federal source for science about the Earth, its natural and living resources, natural hazards, and the environment—visit http://www.usgs.gov or call 1-888-ASK-USGS.

For an overview of USGS information products, including maps, imagery, and publications, visit http://store.usgs.gov.

Any use of trade, firm, or product names is for descriptive purposes only and does not imply endorsement by the U.S. Government.

Although this information product, for the most part, is in the public domain, it also may contain copyrighted materials as noted in the text. Permission to reproduce copyrighted items must be secured from the copyright owner.

Suggested citation:

Emsbo, Poul, Seal, R.R., Breit, G.N., Diehl, S.F., and Shah, A.K., 2016, Sedimentary exhalative (sedex) zinc-lead-silver deposit model: U.S. Geological Survey Scientific Investigations Report 2010-5070-N, 57 p., http://dx.doi.org/10.3133/ sir20105070N.

ISSN 2328-0328 (online) 


\section{Contents}

Introduction

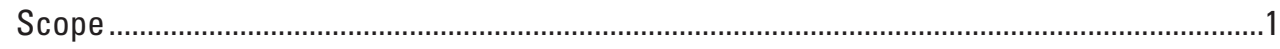

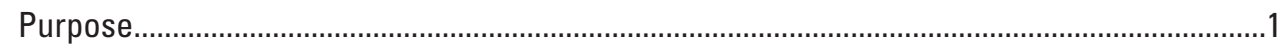

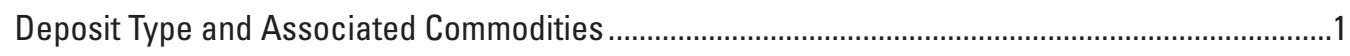

Name

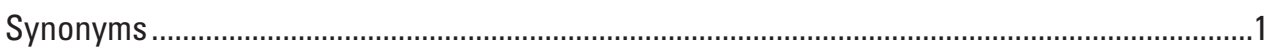

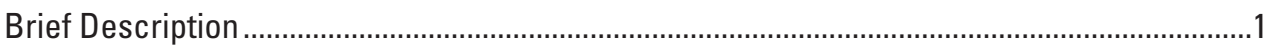

Deposit Model—Clarification and Exclusions ..................................................................

Irish-Type Deposits ..........................................................................................

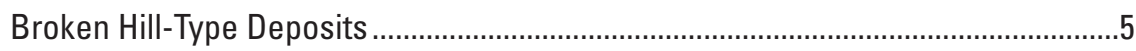

Volcanogenic Massive Sulfide Deposits ...............................................................

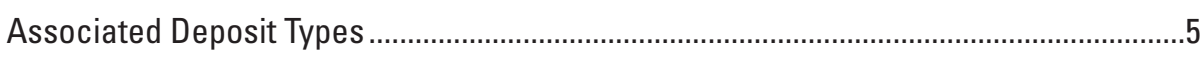

Mississippi Valley-Type and Irish-Type Deposits ………....................................

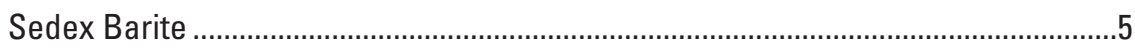

Sediment-Hosted Manganese, Iron, Phosphate, and Metalliferous

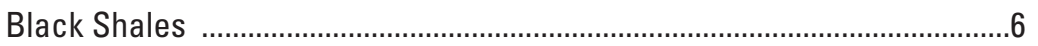

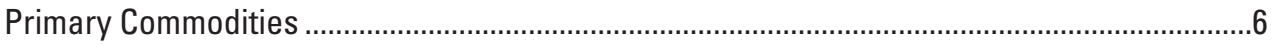

Byproduct Commodities ....................................................................................................

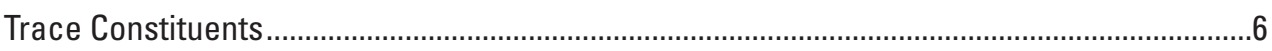

Example Deposits..........................................................................................................

Historical Evolution of Descriptive and Genetic Knowledge and Concepts.....................................6

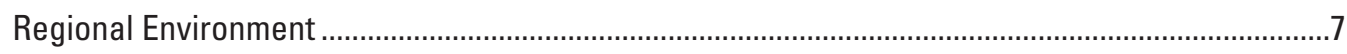

Geotectonic Environment ...................................................................................................

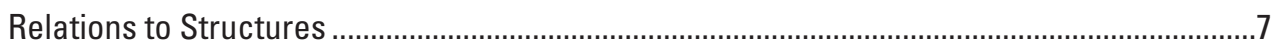

Relations to Sedimentary Rocks ....................................................................................

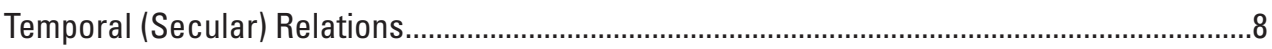

Duration of Hydrothermal System and (or) Mineralizing Processes ......................................10

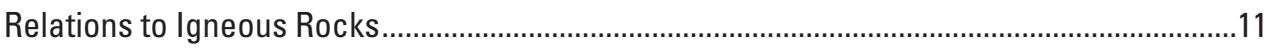

Relations to Metamorphic Rocks .........................................................................................11

Physical Description of Deposit ..........................................................................................11

Dimensions in Plan View ...................................................................................................

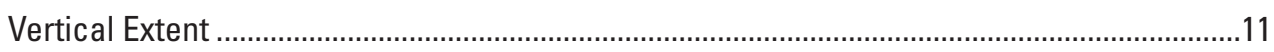

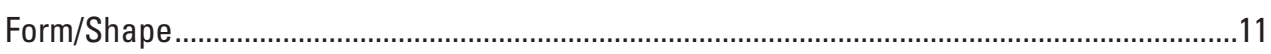

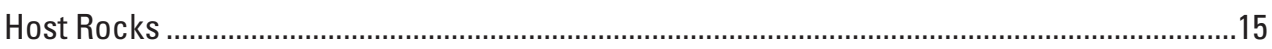

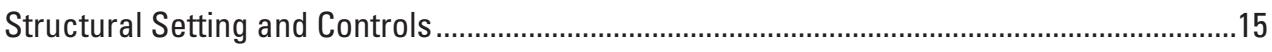

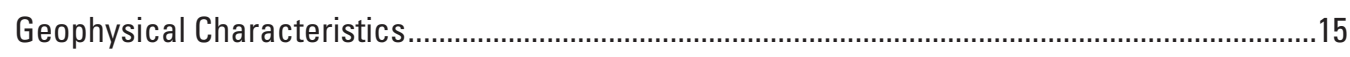

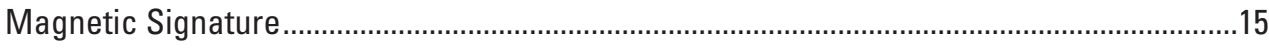

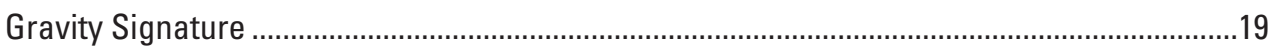

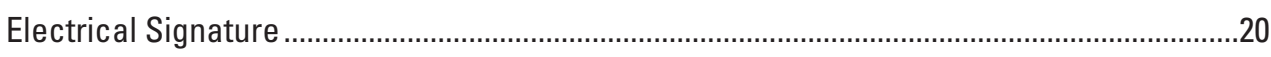

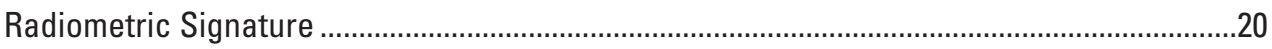




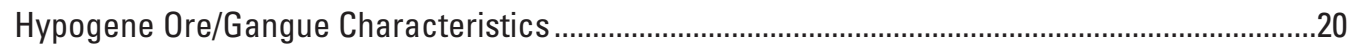

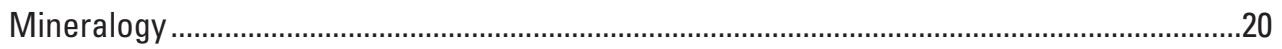

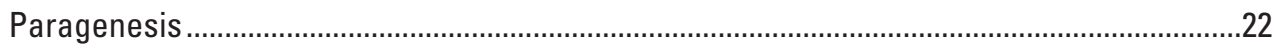

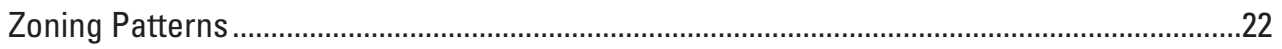

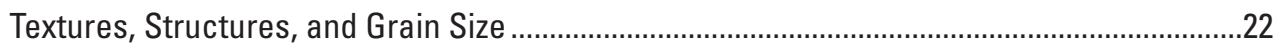

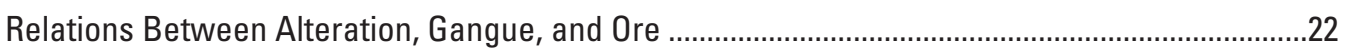

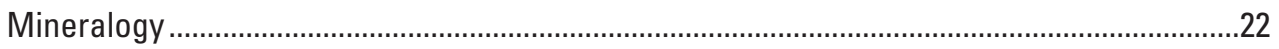

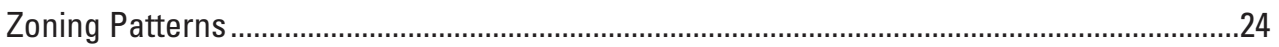

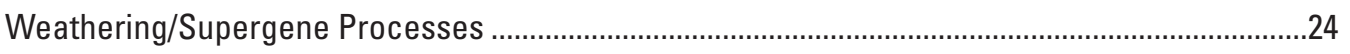

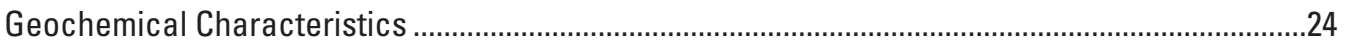

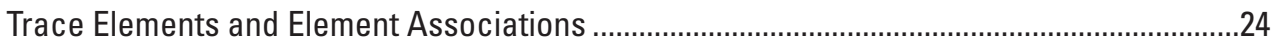

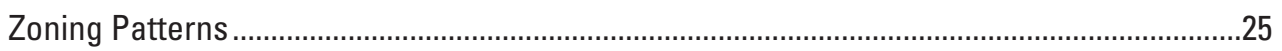

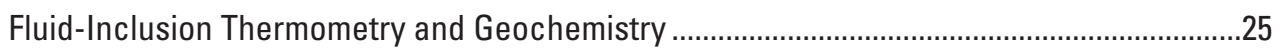

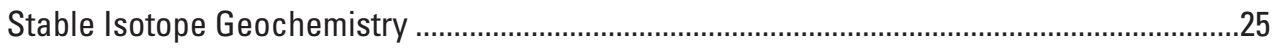

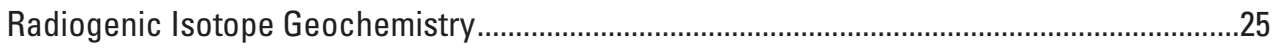

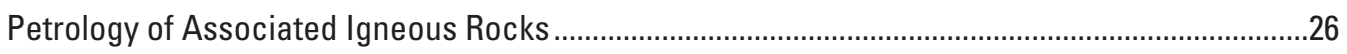

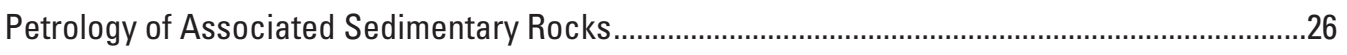

Importance of Sedimentary Rocks to Deposit Genesis........................................................26

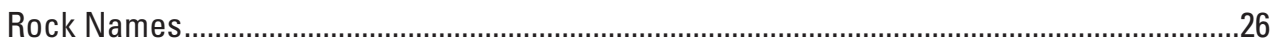

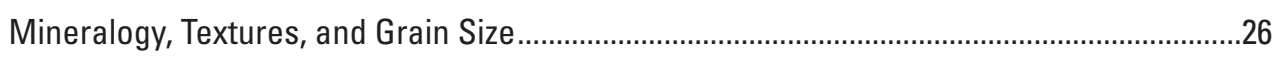

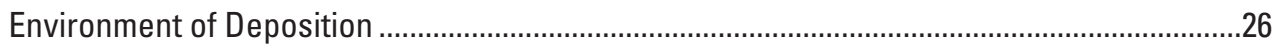

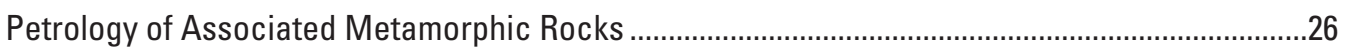

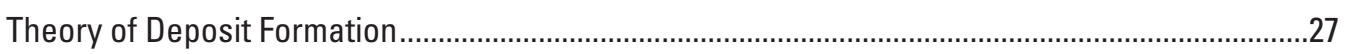

Ore Deposit System Affiliation(s) ...................................................................................2

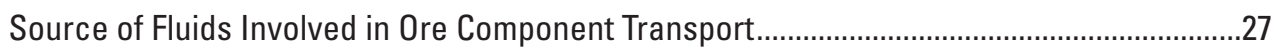

Deduced Geologic Assessment Criteria ......................................................................28

Sources of Ligands and Chemical Transport and Transfer Processes Involved

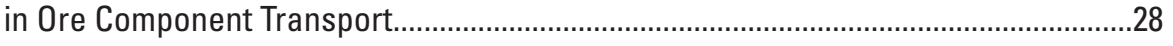

Deduced Geologic Assessment Criteria ...................................................................29

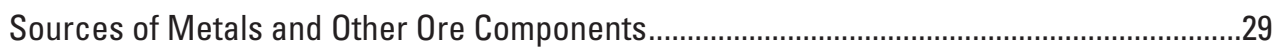

Deduced Geologic Assessment Criteria ..................................................................30

Fluid Drive — Thermal, Pressure, and Geodynamic Mechanisms .........................................30

Sedimentary Compaction Models.............................................................................30

Free Convection Models..........................................................................................

Topographically Driven Flow Models .........................................................................32

Density-Driven Fluid Flow_A New Fluid-Flow Model ...................................................32

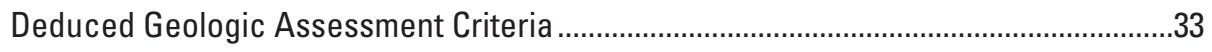

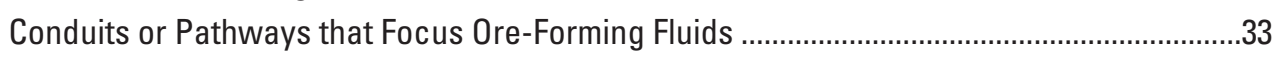

Deduced Geologic Assessment Criteria ....................................................................

Nature of Traps and Wallrock Interaction that Trigger Ore Precipitation................................34

Deduced Geologic Assessment Criteria ......................................................................35

Structure and Composition of Residual Fluid Outflow Zones ...................................................35

Deduced Geologic Assessment Criteria ………………................................................

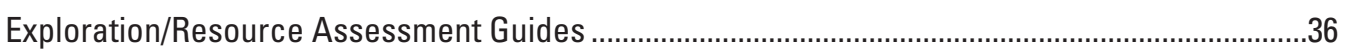

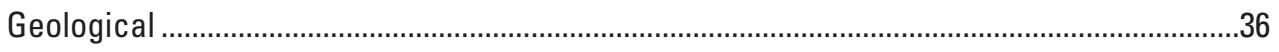


Attributes Required for Inclusion in Permissive Tract at Various Scales ......................................36

Geologic Criteria that Define Permissive Tracts................................................................36

Geologic Criteria Used to Evaluate the Prospectivity of Permissive Tracts ............................36

Knowledge that Enables Favorability Zonation of Permissive Tracts .......................................37

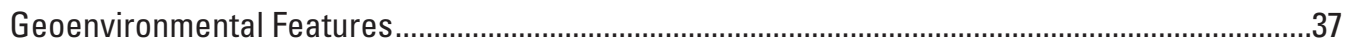

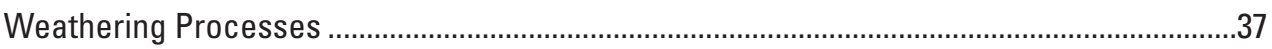

Pre-Mining Baseline Signatures in Soil, Sediment, and Water .......................................................38

Past and Future Mining Methods and Ore Treatment .................................................................39

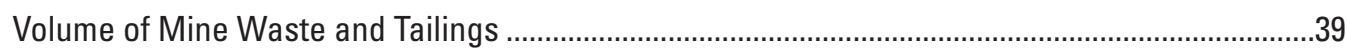

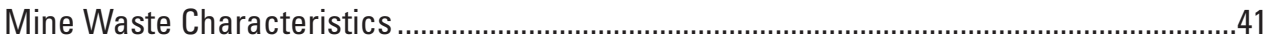

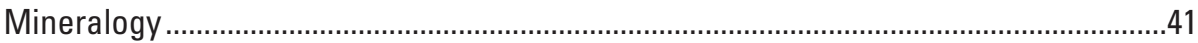

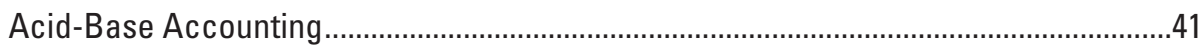

Element Mobility Related to Mining in Groundwater and Surface Water................................43

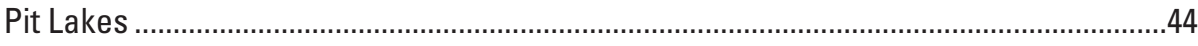

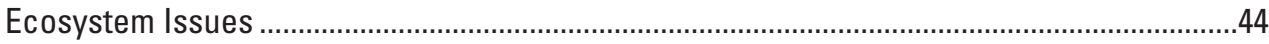

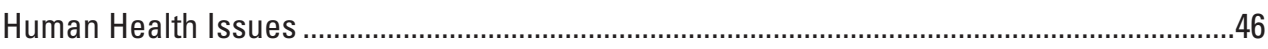

Climate Effects on Geoenvironmental Signatures …….....................................................47

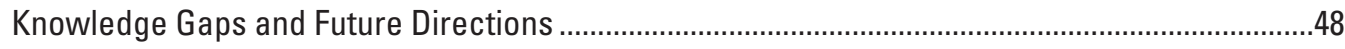

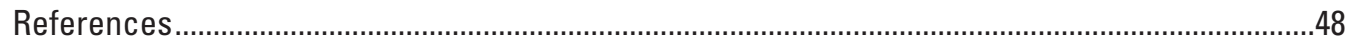

\section{Figures}

1. Global distribution of sedex zinc-lead-sliver deposits with proportional symbol showing contained zinc and lead in tons............................................................

2. Metal endowment in sedex zinc-lead-sliver deposits.......................................................

3. Schematic cross section through a rift-controlled sedimentary basin showing the idealized setting of sedex deposits............................................................

4. Distribution of contained lead and zinc metal in known sedex deposits through time

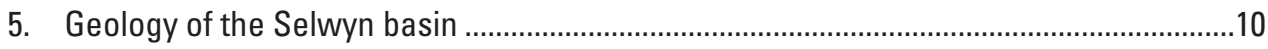

6. Generalized geologic maps of the major sedex mining districts of the

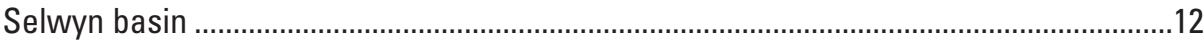

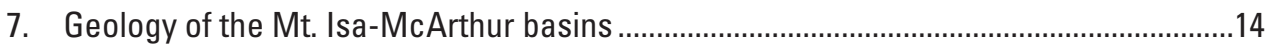

8. Generalized geologic maps of the major sedex mining districts of the Mt. Isa-McArthur basins ............................................................................................16

9. Generalized cross sections showing the structural setting, stratigraphic position, and morphology of other sedex deposits .......................................................18

10. Cross section showing morphology and distribution of ore types and mineralogic and geochemical zoning through an idealized sedex deposit.

11. Photographs of samples illustrating the diversity of textures and mineralogic and geochemical composition of sedex ores

12. Textural evidence showing modification of sedex ores through sea-floor processes, suggesting sedex ores predate compaction and lithification of their host rocks

13. Geologic setting of sedex zinc-lead-silver deposits with deduced geologic assessment criteria as put forth in this report. 
14. Geochemical data for waters associated with unmined sedex massive sulfide deposits: the Red Dog, Drenchwater, and Lik deposits.

15. Acid-base accounting characteristics of waste rock and tailing for the Faro and Red Dog sedex deposits

16. Geochemical data for waters associated with unmined sedex massive sulfide deposits: the Red Dog, Faro, and Troya mine deposits .45

17. Geochemical data for dissolved copper and zinc in drainage associated with sedex deposits.

\section{Tables}

1. Selected common mineralogical characteristics of sedimentaryexhalative deposits with a comparison to volcanic-hosted massive sulfide deposits

2. Maximum environmental guidelines for contaminants relevant to mineral deposits.

\section{Conversion Factors}

International System of Units to U.S. customary units

\begin{tabular}{|c|c|c|}
\hline Multiply & By & To obtain \\
\hline \multicolumn{3}{|c|}{ Length } \\
\hline centimeter $(\mathrm{cm})$ & 0.3937 & inch (in.) \\
\hline millimeter (mm) & 0.03937 & inch (in.) \\
\hline meter (m) & 3.281 & foot $(\mathrm{ft})$ \\
\hline kilometer (km) & 0.6214 & mile (mi) \\
\hline kilometer $(\mathrm{km})$ & 0.5400 & mile, nautical (nmi) \\
\hline meter $(\mathrm{m})$ & 1.094 & yard (yd) \\
\hline \multicolumn{3}{|c|}{ Area } \\
\hline square meter $\left(\mathrm{m}^{2}\right)$ & 0.0002471 & acre \\
\hline square kilometer $\left(\mathrm{km}^{2}\right)$ & 247.1 & acre \\
\hline square meter $\left(\mathrm{m}^{2}\right)$ & 10.76 & square foot $\left(\mathrm{ft}^{2}\right)$ \\
\hline square kilometer $\left(\mathrm{km}^{2}\right)$ & 0.3861 & square mile $\left(\mathrm{mi}^{2}\right)$ \\
\hline \multicolumn{3}{|c|}{ Volume } \\
\hline liter (L) & 33.81402 & ounce, fluid (fl. oz) \\
\hline liter (L) & 2.113 & pint $(\mathrm{pt})$ \\
\hline liter (L) & 1.057 & quart (qt) \\
\hline liter (L) & 0.2642 & gallon (gal) \\
\hline cubic centimeter $\left(\mathrm{cm}^{3}\right)$ & 0.06102 & cubic inch $\left(\mathrm{in}^{3}\right)$ \\
\hline liter $(\mathrm{L})$ & 61.02 & cubic inch $\left(\mathrm{in}^{3}\right)$ \\
\hline cubic kilometer $\left(\mathrm{km}^{3}\right)$ & 0.2399 & cubic mile $\left(\mathrm{mi}^{3}\right)$ \\
\hline \multicolumn{3}{|c|}{ Mass } \\
\hline gram (g) & 0.03527 & ounce, avoirdupois (oz) \\
\hline kilogram (kg) & 2.205 & pound avoirdupois (lb) \\
\hline metric ton $(\mathrm{t})$ & 1.102 & ton, short $[2,000 \mathrm{lb}]$ \\
\hline metric ton $(\mathrm{t})$ & 0.9842 & ton, long $[2,240 \mathrm{lb}]$ \\
\hline \multicolumn{3}{|c|}{ Density } \\
\hline gram per cubic centimeter $\left(\mathrm{g} / \mathrm{cm}^{3}\right)$ & 62.4220 & pound per cubic foot $\left(\mathrm{lb} / \mathrm{ft}^{3}\right)$ \\
\hline
\end{tabular}

Temperature in degrees Celsius $\left({ }^{\circ} \mathrm{C}\right)$ may be converted to degrees Fahrenheit $\left({ }^{\circ} \mathrm{F}\right)$ as follows: ${ }^{\circ} \mathrm{F}=\left(1.8 \times{ }^{\circ} \mathrm{C}\right)+32$

Temperature in degrees Fahrenheit $\left({ }^{\circ} \mathrm{F}\right)$ may be converted to degrees Celsius $\left({ }^{\circ} \mathrm{C}\right)$ as follows: ${ }^{\circ} \mathrm{C}=\left({ }^{\circ} \mathrm{F}-32\right) / 1.8$ 


\section{Abbreviations}

\section{Elements and Minerals}

\begin{tabular}{|c|c|}
\hline $\mathrm{Ag}$ & silver \\
\hline $\mathrm{Al}$ & aluminum \\
\hline As & arsenic \\
\hline $\mathrm{Au}$ & gold \\
\hline $\mathrm{Ba}$ & barium \\
\hline DI & bismuth \\
\hline $\mathrm{Br}$ & bromine \\
\hline C & carbon \\
\hline $\mathrm{Cd}$ & cadium \\
\hline 乙I & chlorine \\
\hline Lo & cobalt \\
\hline $\mathrm{Cu}$ & copper \\
\hline$\Gamma$ & iron \\
\hline 0 & gallium \\
\hline $\mathrm{Hg}$ & mercury \\
\hline In & indium \\
\hline $\mathrm{K}$ & potassium \\
\hline $\mathrm{Mg}$ & magnesium \\
\hline $\mathrm{Mn}$ & manganese \\
\hline Mo & molybdenum \\
\hline $\mathrm{Na}$ & sodium \\
\hline $\mathrm{Ni}$ & nickel \\
\hline 0 & oxygen \\
\hline $\mathrm{P}$ & phosphorus \\
\hline $\mathrm{Pb}$ & lead \\
\hline $\mathrm{Rb}$ & rubidium \\
\hline S & sulfur \\
\hline $\mathrm{Sb}$ & antimony \\
\hline $\mathrm{S}$ & selenium \\
\hline $\mathrm{S}$ & tin \\
\hline $\mathrm{Sr}$ & strontium \\
\hline $\mathrm{T}$ & thallium \\
\hline $\mathrm{T}$ & thorium \\
\hline 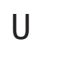 & uranium \\
\hline$n$ & zinc \\
\hline
\end{tabular}




$\begin{array}{ll}\mathrm{BaSO}_{4} & \text { barite } \\ \mathrm{CaCO}_{3} & \text { calcite; calcium carbonate } \\ \text { Corg } & \text { organic matter } \\ \mathrm{Fe}^{2+} & \text { ferrous iron } \\ \mathrm{Fe}^{3+} & \text { ferric iron } \\ \mathrm{FeS}_{2} & \text { pyrite } \\ \mathrm{H}_{2} \mathrm{~S} & \text { hydrogen sulfide } \\ \mathrm{O}_{2} & \text { dissolved oxygen } \\ \mathrm{PbCO}_{3} & \text { cerussite } \\ \mathrm{PbS} & \text { galena } \\ \mathrm{PbSO}_{4} & \text { anglesite } \\ \mathrm{PO}_{4} & \text { phosphate } \\ \mathrm{Fe}_{1-\mathrm{x}} \mathrm{S} & \text { pyrrhotite } \\ \mathrm{S}_{\mathrm{metal}} & \text { pyrite sulfur } \\ \mathrm{SO}_{2} & \text { sulfur dioxide } \\ \mathrm{SO}_{4} & \text { sulfate } \\ \mathrm{ZnS} & \text { sphalerite } \\ & \end{array}$

\section{Units of Measure}

\begin{tabular}{|c|c|}
\hline$<$ & less than \\
\hline$>$ & greater than \\
\hline${ }^{\circ} \mathrm{C}$ & degree Celsius \\
\hline${ }^{\circ} \mathrm{C} / \mathrm{km}$ & degree Celsius per kilogram \\
\hline$\mu \mathrm{m}$ & micrometer \\
\hline $\mathrm{cm}$ & centimeter \\
\hline $\mathrm{g} / \mathrm{cm}^{3}$ & gram per cubic centimeter \\
\hline$g / L$ & gram per liter \\
\hline $\mathrm{Ga}$ & giga-annum (billion years ago) \\
\hline $\mathrm{kg} \mathrm{CaCO}_{3} / \mathrm{t}$ & kilogram of calcium carbonate per metric ton of material \\
\hline $\mathrm{km}$ & kilometer \\
\hline $\mathrm{km}^{2}$ & square kilometer \\
\hline $\mathrm{km}^{3}$ & cubic kilometer \\
\hline $\mathrm{m}$ & meter \\
\hline m.y. & million years \\
\hline $\mathrm{Ma}$ & mega-annum (million years ago) \\
\hline $\mathrm{mg} / \mathrm{kg}$ & milligram per kilogram \\
\hline $\mathrm{mg} / \mathrm{L}$ & milligram per liter \\
\hline $\mathrm{mm}$ & millimeter \\
\hline Mt & million metric tons \\
\hline
\end{tabular}




\begin{tabular}{|c|c|}
\hline $\mathrm{MW} / \mathrm{m}^{2}$ & megawatt per square meter \\
\hline ppm & part per million \\
\hline $\mathrm{t}$ & tonnage (in metric tons) \\
\hline vol. percent & volume percent \\
\hline $\mathrm{W} / \mathrm{m} \cdot{ }^{\circ} \mathrm{C}$ & watt per meter degree Celsius \\
\hline wt. percent & weight percent \\
\hline \multicolumn{2}{|l|}{ Other } \\
\hline ABA & acid-base accounting \\
\hline AP & acid-generating potential \\
\hline BHT & Broken Hill-type \\
\hline MVT & Mississippi Valley-type \\
\hline NNP & net neutralization potential (NP - AP) \\
\hline NP & acid-neutralizing potential \\
\hline NPR & neutralizing potential ratio (NP:AP) \\
\hline NURE & National Uranium Resource Evaluation \\
\hline redox & reduction-oxidation \\
\hline sedex & sedimentary exhalative \\
\hline TDS & total dissolved solids \\
\hline TOC & total organic carbon \\
\hline VMS & volcanogenic massive sulfide \\
\hline XRF & $x$-ray fluorescence \\
\hline
\end{tabular}





\title{
Sedimentary Exhalative (Sedex) Zinc-Lead-Silver Deposit Model
}

\author{
By Poul Emsbo, Robert R. Seal, George N. Breit, Sharon F. Diehl, and Anjana K. Shah
}

\section{Introduction}

Sedimentary exhalative (sedex) deposits account for more than 50 percent of the world's zinc $(\mathrm{Zn})$ and lead $(\mathrm{Pb})$ reserves (Tikkanen, 1986) and furnish more than 25 percent of the world's current production of these two metals and a significant amount of silver (Ag) (Goodfellow and Lydon, 2007). More than 129 deposits of this type have been recognized in sedimentary basins around the world (Leach and others, 2005b; Goodfellow and Lydon, 2007). A compilation by Taylor and others (2009) shows that deposits occur in 25 sedimentary basins, 7 of which contain more than 10 million metric tons $(\mathrm{Mt})$ of combined $\mathrm{Pb}+\mathrm{Zn}$ (figs. 1, 2). In order of decreasing endowment, these basins are the Mt. IsaMcArthur basins, Australia (7 deposits containing $112 \mathrm{Mt}$ of $\mathrm{Zn}+\mathrm{Pb}$ metal); Selwyn basin, Canada (17 deposits, $55 \mathrm{Mt}$ ); Brooks Range, Alaska, United States (3 deposits, $40 \mathrm{Mt}$ ); Kholodninskoye deposit, Russia (1 deposit, $23 \mathrm{Mt}$ ); Rajasthan basin, India (5 deposits, $20 \mathrm{Mt}$ ); Belt-Purcell basin, United States and Canada (1 deposit, $19 \mathrm{Mt}$ ); and Rhenish basin, Germany (2 deposits, $11 \mathrm{Mt}$ ) (fig. 1).

\section{Scope}

Descriptions, data, conceptual/genetic models, and geoenvironmental assessments for sedex deposits have been compiled and reviewed previously (Kelley and others, 1995; Lydon, 1995; Leach and others, 2005b; Goodfellow and Lydon, 2007). Extensive and up-to-date grade-tonnage compilations of sedex deposits are available in the literature (Goodfellow and Lydon, 2007; Taylor and others, 2009). This report draws on previous syntheses and basic research studies of sedex deposits to arrive at the defining criteria, both descriptive and genetic, for sedex-type deposits. Studies of the tectonic, sedimentary, and fluid evolution of modern and ancient sedimentary basins have also been used to select defining criteria. The focus here is on the geologic characteristics of sedex deposit-hosting basins that contain greater than $10 \mathrm{Mt} \mathrm{Zn+Pb}$. The enormous size of sedex deposits strongly suggests that basin-scale geologic processes are involved in their formation. It follows that mass balance constraints of basinal processes can provide a conceptual underpinning for the evaluation of potential ore-forming mechanisms and the identification of geologic indicators for ore potential in specific sedimentary basins.

\section{Purpose}

The objective of this report is to develop a model for sedex deposits based on processes critical to their formation. The framework for the model development is a "mineral systems approach" (see Kreuzer and others, 2008) that draws on both descriptive information and genetic consideration. The mineral system schemes have varied in detail, but critical elements of hydrothermal ore-forming processes include (1) source of fluids, (2) source of metal-transporting ligands, (3) source of metals, (4) drivers of fluid movement, (5) plumbing systems or pathways, (6) physical and chemical traps for metal, and (7) discharge zones for spent hydrothermal fluids. Empirical data and a genetic understanding of the physicochemical, geologic, and mass balance conditions required for each of these elements are used to establish a hierarchy of quantifiable geologic criteria that can be used in U.S. Geological Survey national assessments (see Johnson and others, 2008) for sedex $\mathrm{Zn}-\mathrm{Pb}-\mathrm{Ag}$ deposits.

\section{Deposit Type and Associated Commodities}

\section{Name}

Sedex $\mathrm{Pb}-\mathrm{Zn}-\mathrm{Ag}$ deposits

\section{Synonyms}

The term sedex, derived from sedimentary exhalative (Carne and Cathro, 1982), is based on the interpretation that the finely laminated or bedded sulfide ores that characterize this deposit type are chemical sediments that precipitated from hydrothermal fluids that had been "exhaled" or vented onto the sea floor. The merits of using a genetic criterion such as this to define a deposit type has been a subject of considerable debate, leaving some researchers to use purely descriptive terminology such as shale-hosted $\mathrm{Zn}-\mathrm{Pb}-\mathrm{Ag}$ deposits or sediment-hosted stratiform $\mathrm{Zn}-\mathrm{Pb}-\mathrm{Ag}$ deposits instead of sedex deposits (see Leach and others, 2005b).

\section{Brief Description}

Sedex $\mathrm{Zn}-\mathrm{Pb}-\mathrm{Ag}$ deposits are hosted by marine sedimentary rocks of intracratonic or epicratonic rift basins. Host rocks are carbonaceous shales, siltstones, and (or) carbonates 
of basin sag-phase sequences that were deposited on thick rift-fill sequences of sandstones, siltstones, conglomerates, red beds, and mafic or felsic volcanic rocks. Most deposits show no association with intrusive rocks. Orebodies are generally tabular or stratiform and are localized in smaller faultcontrolled subbasins near the margins of major depocenters and outboard of shallow-water carbonate platforms margins. Laminated or bedded sulfide ores in carbonaceous, pyritic, fine-grained shales and siltstones are characteristic of this deposit type. The principal ore minerals, sphalerite and galena, precipitated on or just below the sea floor from warm, saline basin brines (approx. 100-200 ${ }^{\circ} \mathrm{Celsius}[\mathrm{C}]$ and $17-30$ percent total dissolved solids) that ascended along basin-controlling synsedimentary faults. The metals were deposited and sequestered by the precipitation of sulfide minerals as a consequence of mixing of the metal-transporting brine and the hydrogen sulfide $\left(\mathrm{H}_{2} \mathrm{~S}\right)$ produced locally by bacterial, and perhaps thermochemical, reduction of local seawater sulfate.

\section{Deposit Model—Clarification and Exclusions}

According to the original definition of Carne and Cathro (1982), sedex deposits are bedded or laminated, tabular sulfide-rich bodies that are hosted in carbonaceous shales or other, fine-grained clastic rocks. The sedex classification has been broadened substantially by subsequent researchers to include several genetically or geologically related deposit types (Lydon, 1996; Leach and others, 2005b; Goodfellow and Lydon, 2007). The model set forth in this report adheres in a general way to the original definition because some variants, although formed by similar genetic processes, are sufficiently different to justify their own deposit models. This section identifies deposit subtypes that require their own geologic model and are not included in our definition of sedex deposits.

Sangster (2002) separated sedex deposits into vent proximal and vent distal types based on the presence or absence of discordant, feeder, vent/stringer zones below the stratiform ore. Whereas the presence or absence of discordant zones might reflect different geologic and hydrologic processes during ore formation, the differences are insufficient to warrant separate mineral deposit models. Varying proportions of base metals, barium (Ba), and gold (Au) led Emsbo (2000) to classify sedex deposits into very large $\mathrm{Zn}-\mathrm{Pb}-\mathrm{Ag}$, intermediate size $\mathrm{Zn}-\mathrm{Pb}-\mathrm{Ag}-\mathrm{Ba} \pm \mathrm{Au}$, and low base metal $\mathrm{Ba}$ and (or) $\mathrm{Au}$ deposits that do not produce $\mathrm{Zn}-\mathrm{Pb}$. Very large $\mathrm{Zn}-\mathrm{Pb}-\mathrm{Ag}$ deposits like the McArthur River (HYC), Century, Mount Isa, Sullivan, and Howards Pass deposits represent the base metalrich end member of sedex deposits. They are enormous, with

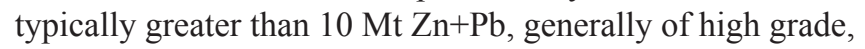
have gold contents near crustal abundance, and contain very little barite. The Red Dog deposit is an enormous gold-poor $\mathrm{Zn}-\mathrm{Pb}-\mathrm{Ag}$ deposit, but it also contains significant amounts of barite. Barite, however, is not temporally coincident with most of the sulfide mineralization as it is replaced by and therefore older than the $\mathrm{Zn}-\mathrm{Pb}$ sulfides, and there is a general lack of spatial correlation between $\mathrm{Ba}$ and $\mathrm{Zn}-\mathrm{Pb}-\mathrm{Ag}$ in the rest of the western Brooks Range (Young, 1989; Kelley and others, 2004a). Intermediate $\mathrm{Zn}-\mathrm{Pb}-\mathrm{Ag}-\mathrm{Ba} \pm \mathrm{Au}$ deposits like the Rammelsberg, Tom, and Jason deposits and those of the Anvil district are generally smaller with less than $7 \mathrm{Mt} \mathrm{Zn}+\mathrm{Pb}$, have associated high-grade barite, and can contain significant gold grades. This classification reflects variation in the concentration and reduction-oxidation (redox) state of sulfur (S) in the brine, which is ultimately controlled by the lithology and redox buffering capacity of basin-fill sediments that make up the metal source region (Lydon and others, 1979, 1985; Emsbo and others, 1999; Cooke and others, 2000; Emsbo, 2000).

Whereas the lithology of basin fill is an important component of the model developed in this report and has implications for deposit formation, metal endowment, and prospectivity of sedimentary basins, the specific geologic conditions that lead to a reduced, low-sulfate $\left(\mathrm{SO}_{4}\right)$, high- $\mathrm{H}_{2} \mathrm{~S}$ brine capable of forming the barite-Au end member are not discussed here. The recognition that sedex ores can form through the replacement of carbonate sediments below the sea floor has led to a "carbonate-hosted" sedex subclassification (Goodfellow and others, 1993; Sangster and Hillary, 2000; Leach and others, 2005b; Goodfellow and Lydon, 2007). Though it is arguably a valid sedex subtype, the distinctions among carbonatehosted sedex deposits, Irish-type deposits, and Mississippi Valley-type deposits are somewhat subjective. Deposits formed within carbonate platforms on basin margins, inboard of clastic depocenters, are not properly assessed by our sedex model because these deposits are dominated by sub-sea-floor replacement processes and are not directly associated with organic-rich sediments. However, deposits formed through the replacement of carbonate turbidities within shale sequences, such as the Anarraaq deposit in Alaska (Kelley and others, 2004a), are well represented by this model because they form in distal clastic depocenters outboard of the shallow carbonate platform margin and because ore sulfides are deposited by $\mathrm{H}_{2} \mathrm{~S}$ from bacterial sulfate reduction in the local organic-rich sedimentary environment (Johnson and others, 2004; Kelley and others, 2004b).

The following sections address deposit types not considered in this report because we classify them as distinct from the sedex model.

\section{Irish-Type Deposits}

Irish-type deposits are thought to represent a style of metal accumulation intermediately between sedex and Mississippi Valley-type (MVT) deposits and consequently have been considered as subclasses of both sedex deposits (Goodfellow and others, 1993; Lydon, 1995; Goodfellow and Lydon, 2007) and MVT deposits (Leach and others, 2005b). Irish-type deposits

Figure 1 (facing page). Global distribution of sedex zinc-leadsliver deposits with proportional symbol showing contained zinc and lead in tons. Insets show distribution of deposits in the $(A)$ Selwyn, $(B)$ Belt-Purcell, $(C)$ Rajasthan, and $(D)$ Mt. IsaMcArthur basins. (Data from Taylor and others, 2009) 


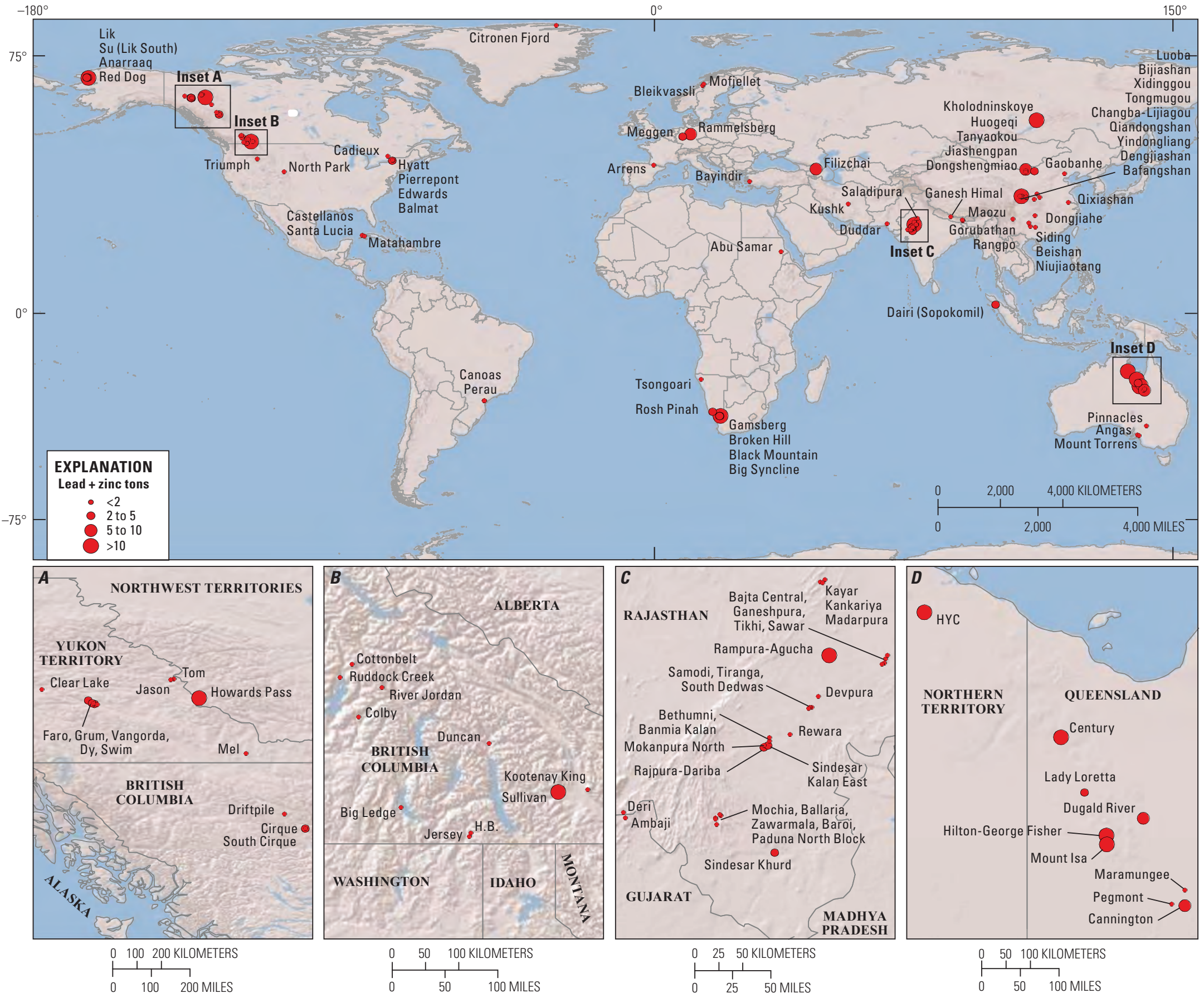




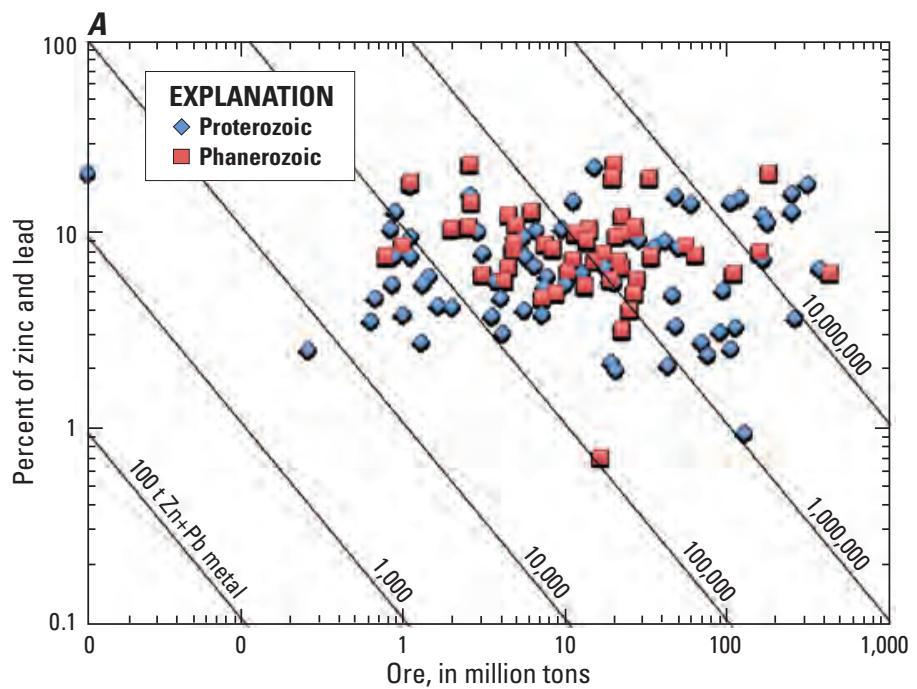

$B$

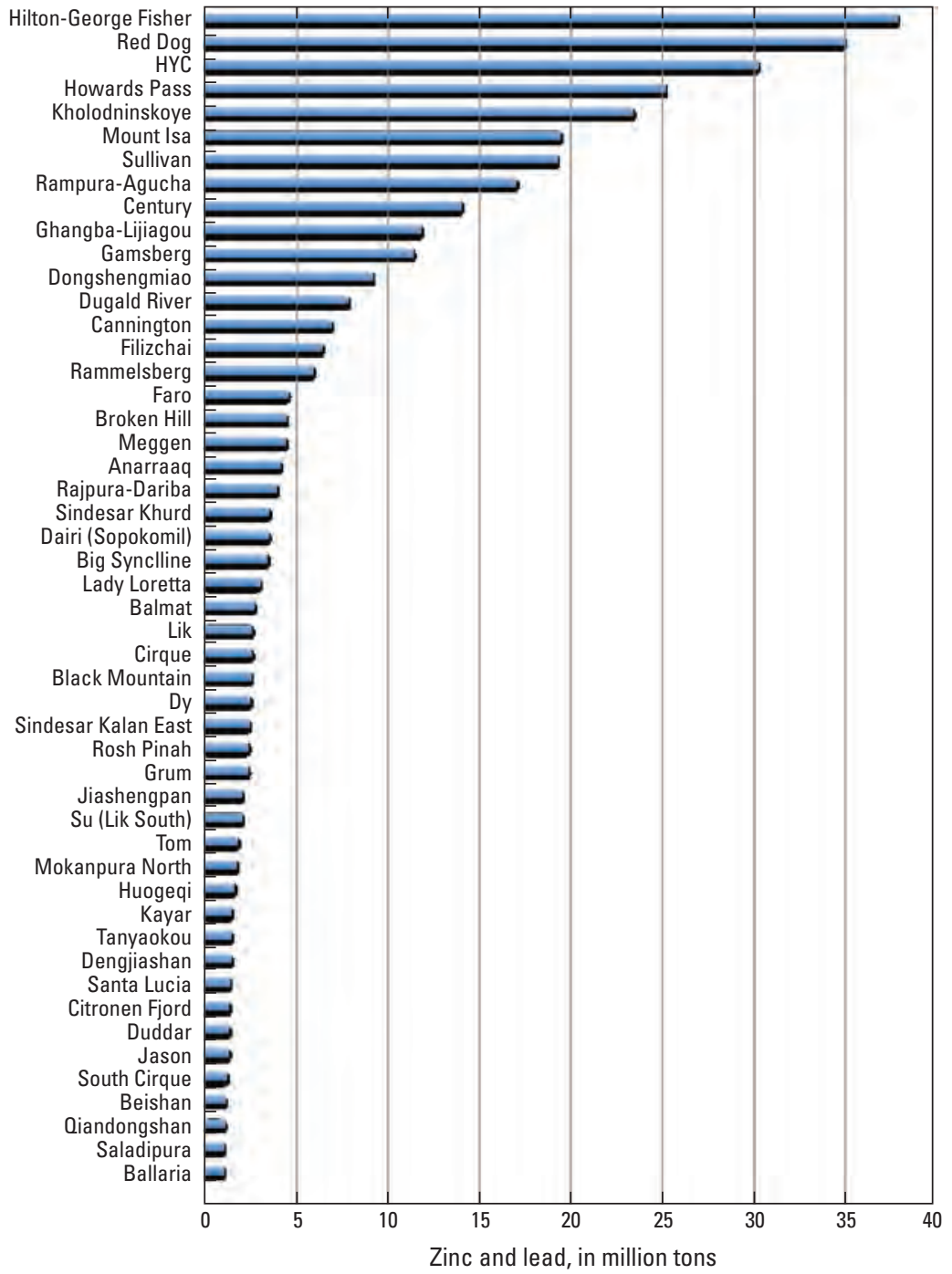

Figure 2. Metal endowment in sedex zinc-lead-sliver deposits. $A$, Gradetonnage for 122 sedex deposits. Diagonal lines represent tonnage $(t$, in metric tons) of zinc and lead $(\mathrm{Zn}+\mathrm{Pb})$ metal in the deposits. $B$, Bar diagram showing the 50 largest sedex deposits with the largest amounts of contained $\mathrm{Zn}+\mathrm{Pb}$ metal. (Data from Taylor and others, 2009) 
share many characteristics of sedex deposits. For example, (1) they have similar grade-tonnage characteristics, (2) they occur in the sag phase of intracratonic and epicratonic rift systems in association with evaporative environments, (3) they were formed from basin brine, and (4) metals were deposited immediately below the sea floor by mixing with $\mathrm{H}_{2} \mathrm{~S}$ derived from bacterial sulfate reduction in overlying organic-rich seafloor sediments (Hitzman and Beaty, 1996; Leach and others, 2005b; Wilkinson and others, 2005). Although the sedex model presented in this report captures many of these processes and characteristics, there are significant differences, namely that Irish-type deposits form through the replacement of carbonates deposited on basin platform margins rather than in the clastic depositional settings within major depocenters.

\section{Broken Hill-Type Deposits}

Whether or not Broken Hill-type (BHT) deposits are a subtype of sedex deposits has been vigorously debated (see Leach and others, 2005b). The BHT deposits are all highly metamorphosed, but it is not entirely clear why metamorphism of a deposit after its formation should be a distinguishing criterion, as some have proposed. However, BHT deposits display distinctive empirical/genetic features that are unaccounted for by this sedex model. Most significantly, (1) BHT deposits are formed during the rift phase rather than the sag phase of basin development, (2) sulfide ores are interbedded with oxidefacies iron (Fe)- and manganese (Mn)-rich rocks, (3) gradetonnage characteristics are distinctive and include higher Ag grades and $\mathrm{Pb}: \mathrm{Zn}$ ratios (Leach and others, 2005b), (4) trace element signatures are distinct, (5) important examples are not hosted by organic-rich sediments, (6) ore sulfides typically have narrow $\delta^{34} \mathrm{~S}$ ranges that suggest distinctive mechanisms and (or) environments of ore deposition (Large and others, 1996a), and (7) some examples show possible links to igneous activity. Despite these differences, similarities between sedex and BHT deposits suggest genetic links and that a spectrum may exist between the two deposit types. Several significant deposits appear to be such intermediates. For example, deposits in the dismembered Proterozoic Namaqua-Natal metamorphic complex of South Africa are generally considered to be BHT deposits (Stalder and Rozendaal, 2004; Leach and others, 2005b). Several of the deposits in the district, however, including the world-class Gamsberg deposit, display sedex features such as occurrence within a regionally extensive graphitic black shale (metapelite), widely ranging $\delta^{34} \mathrm{~S}$ values for ore sulfides (6.2-32 per mil [\%o]), massive barite both as a cap and as a distal facies, and a peripheral oxide facies, including Fe formation, although oxide facies also occur in the deposit as a feature of the BHT subtype. Unfortunately, tectonism and metamorphism have obscured details of the basin settings of these deposits, but they are thought to have formed during the rift phase of basin development.

The Sullivan deposit is considered by many to be the archetypal sedex deposit. It bears some similarities to BHT deposits, including its formation during the rift-fill sequence of basin development (Lydon, 2004a), but it is similar enough to typical sedex deposits that Sullivan is included in the present report as a sedex deposit.

\section{Volcanogenic Massive Sulfide Deposits}

Several authors have proposed that sedex deposits have a genetic relation to volcanogenic massive sulfide (VMS) deposits (Goodfellow and others, 1993; Large and others, 2001, 2002). Linkage between the two deposit types has been suggested based on modern sediment-hosted VMS occurrences in the Middle Valley, Escanaba Trough, and Guaymas Basin that lie above sediment-covered spreading centers (Goodfellow and others, 1993). Although sedex deposits and sediment-hosted VMS deposits have some similarities, particularly sulfide deposition on or just below the sea floor, true sedex deposits are distinguished by their occurrence in sedimentary basins formed during the sag phase of intracratonic and epicratonic rift systems, the involvement of brines derived from the host basins, and the lack of spatial/genetic associations with volcanic rocks. The VMS deposits are not appropriately assessed by the model developed in this report because they formed from seawater modified during hydrothermal convection in volcanic-dominated systems and not from sedimentary basinal brines (Emsbo, 2000).

\section{Associated Deposit Types}

\section{Mississippi Valley-Type and Irish-Type Deposits}

The co-occurrence of MVT Zn-Pb-Ag deposits in the Mackenzie/Macdonald carbonate platforms and sedex deposits in the Selwyn basin has long been noted and considered suggestive of a genetic link (Sangster, 1990; Goodfellow and others, 1993). The age of these MVT deposits is controversial because of conflicting isotopic and paleomagnetic ages (Nelson and others, 2002; Paradis and Nelson, 2007), but Devonian rubidium/strontium $(\mathrm{Rb} / \mathrm{Sr})$ dates of ore sphalerite and correspondence of radiogenic $(\mathrm{Sr}, \mathrm{Pb})$ and stable (carbon [C], oxygen [O]) isotopes have been used to argue that the MVT deposits in the Macdonald carbonate platform are farfield consequences of sedex deposits as fluids from the deeper part of the basin migrated into the carbonate platform (Nelson and others, 2002; Paradis and Nelson, 2007). An interesting finding of the analysis presented here is that all the important sedex deposit-hosting basins, with the exception of the BeltPurcell basin (northwestern United States and Canada), have MVT deposits in associated basin-margin platform carbonates. The co-occurrence of both types of mineralization in the same basins supports previous interpretations that sedex and MVT deposits may be genetically linked.

\section{Sedex Barite}

Barite-only deposits are typically closely associated with sulfide deposits but are also found far removed from them (tens of kilometers) in the same stratigraphic horizons (Lydon and others, 1979; Emsbo and Johnson, 2004; Kelley and Jennings, 2004; Johnson and others, 2009). 
Sediment-Hosted Manganese, Iron, Phosphate, and Metalliferous Black Shales

Diverse sediment-hosted deposit types, including organic-rich metalliferous black shales, $\mathrm{Mn}$, and phosphate $\left(\mathrm{PO}_{4}\right)$, commonly occur in the same sedimentary horizons as sedex deposits (Goodfellow and others, 1993; Lydon, 1995; Large and others, 1998; Emsbo, 2004, 2008; Emsbo and others, 2005). These deposit types are interpreted by some researchers to have resulted from the upwelling of cold ocean waters - rich in biolimiting nutrients $\mathrm{Mn}, \mathrm{Fe}$, and $\mathrm{PO}_{4}$ - onto the continental shelves (Goodfellow and Jonasson, 1987; Goodfellow and Lydon, 2007; Slack, 2008). The waters would trigger an increase in bioproductivity and eutrophication and thus precipitation of $\mathrm{Mn}, \mathrm{Fe}$, and $\mathrm{PO}_{4}$. It has also been argued that the sedex ore fluids introduced the biolimiting nutrients and the resulting eutrophication and formation of these diverse deposits are, therefore, far-field consequences of sedex formation (Emsbo and others, 1999; Emsbo, 2004, 2008).

\section{Primary Commodities}

Zinc and lead are the primary commodities for sedex deposits. On average, sedex deposits contain approximately 7 percent $\mathrm{Zn}$ and 3 percent $\mathrm{Pb}$ metal (fig. 2).

\section{Byproduct Commodities}

The main byproduct commodities produced from sedex deposits include $\mathrm{Ag}$, copper $(\mathrm{Cu})$, and $\mathrm{Ba}$. Sedex deposits average about 60 parts per million (ppm) Ag and represent a significant source of Ag. The Red Dog deposit, for example, is currently the leading Ag producer in the United States (Brooks, 2012). In a few deposits, such as Rammelsberg and Mount Isa, $\mathrm{Cu}$ is an important economic resource. Most sedex deposits receive refinery credits for cadmium (Cd) that is hosted in sphalerite at concentrations as high as 1 percent (Schwartz, 1997). Barite is present in about 25 percent of the Proterozoic and about 75 percent of the Phanerozoic sedex deposits (Goodfellow and others, 1993); in some cases, it makes up more than 25 percent of ores and is economically recovered. Although the Au content of sedex deposits is typically low (approx. equal to 2 parts per billion), the Anvil district and the Rammelsberg, Triumph, and Sullivan deposits have produced $\mathrm{Au}$ (Emsbo, 2000). Ore from the Anvil district and the Rammelsberg and Triumph deposits averaged nearly $1 \mathrm{ppm} \mathrm{Au}$, with local concentrations as high as $30 \mathrm{ppm}$ in the Rammelsberg deposits (Emsbo, 2000). Similarly, though tin (Sn) is typically low (less than $1 \mathrm{ppm}$ ) in most sedex deposits, a few deposits contain appreciable amounts of Sn. For example, the Sullivan deposit has produced Sn from ore that averaged $300 \mathrm{ppm}$ with local concentrations as high as 2,000 ppm (mainly from cassiterite) in the vent complex (Lydon, 2004b). Although not recovered, $\mathrm{Sn}$ in the Rammelsberg deposit averaged $50 \mathrm{ppm}$ with local concentrations as high as $730 \mathrm{ppm}$ (Large and Walcher, 1999).

\section{Trace Constituents}

In addition to the ore-forming elements, a large suite of associated elements characterizes sedex deposits. Elements such as $\mathrm{Fe}, \mathrm{Mn}$, phosphorus (P), Ba, mercury ( $\mathrm{Hg}), \mathrm{Cd}$, arsenic (As), antimony ( $\mathrm{Sb}$ ), thallium (Tl), and selenium (Se), are universally elevated. Elements such as Sn, indium (In), gallium $(\mathrm{Ga})$, bismuth (Bi), cobalt (Co), nickel (Ni), and $\mathrm{Tl}$ have also been reported in some deposits (Goodfellow and others, 1993; Goodfellow, 1987; Goodfellow and Rhodes, 1991). Many of these elements (that is, $\mathrm{As}, \mathrm{Sb}, \mathrm{Bi}, \mathrm{Hg}, \mathrm{In}, \mathrm{Tl}$ ) can also be detrimental to mining operations as they can result in smelter penalties during ore refining and geoenvironmental liability during mining.

\section{Example Deposits}

Well-studied examples of sedex $\mathrm{Zn}-\mathrm{Pb}$-Ag deposits include Red Dog (Brooks Range); McArthur River (HYC), Century, Mount Isa, and Hilton-George Fisher (Mt. IsaMcArthur basins); Rammelsberg and Meggen (Rhenish basin); Howards Pass, Tom, Jason, and the Anvil district (Selwyn basin); and Sullivan (Belt-Purcell basin).

\section{Historical Evolution of Descriptive and Genetic Knowledge and Concepts}

While sedex deposits have been exploited for as much as a millennium, as is the case for Rammelsberg, the geologic and geochemical processes that formed these deposits were poorly understood until the late 1970s and early 1980s. Since then, a series of descriptive and genetic models have established sedex deposits as a distinct deposit type and have shaped our current understanding of the geologic processes that formed these enormous deposits. The analysis of sedex deposit-hosting sedimentary basins by Large $(1980,1983)$ established the relation between sedex deposits and basin architecture and geotectonic environment. The suggestions that sedex deposits were formed by saline basinal brines (Hutchinson, 1980; Badham, 1981; Lydon, 1983), now verified by a series of studies (Gardner and Hutcheon, 1985; Ansdell and others, 1989; Bresser, 1992; Leach and others, 2004; Polito and others, 2006), was a critical advance in formulating a theory for sedex deposit genesis. The realization that sedex deposits were formed from brines that are geochemically similar to those that formed MVT deposits and those in modern basins fostered cross-pollination with burgeoning geochemical, fluid inclusion, and thermodynamic modeling studies of modern and ancient brines. Integration of the results from these related fields have provided invaluable insights and geochemical constraints into the source, transport, and deposition of metals in sedimentary basins. 
The radiogenic and stable isotopic compositions of sedex ores constrain the sources of ore components. Many studies have demonstrated that $\mathrm{Pb}$ and $\mathrm{Sr}$ are derived from well-mixed upper crustal rocks, most likely from the continental clastic sediments contained in host basins (Gustafson and Williams, 1981; Goodfellow and others 1993; Lydon, 1996; Ayuso and others, 2004; Emsbo and Johnson, 2004; Large and others, 2005; Leach and others, 2005b). Chemical modeling studies have emphasized the importance of oxidized clastic sediments (such as red beds, conglomerates, and sandstones) in source rocks in underlying rift-fill sequences (Emsbo and others, 1999; Cooke and others, 2000; Emsbo, 2000). The identified sources of metals and ore fluids have been central in developing models for the hydrologic processes that drove the enormous hydrothermal systems responsible for the formation of sedex deposits (Russell and others, 1981; Lydon, 1983, 1986; Sawkins, 1984; Goodfellow and others, 1993; Garven and others, 2001; Leach and others, 2004; Yang and others, 2004; Large and others, 2005).

Because of the importance of $\mathrm{H}_{2} \mathrm{~S}$ in trapping ore metals and forming sedex deposits, its source has been a focus of many studies. While interpretations of sulfur sources have varied, there is now general consensus that the ultimate source was marine sulfate that had been reduced to $\mathrm{H}_{2} \mathrm{~S}$ through bacterial sulfate reduction and, perhaps, thermochemical sulfate reduction (Sangster, 1968; Large and others, 2002, 2005; Lydon, 2004a; Leach and others, 2005b; Goodfellow and Lydon, 2007). The original suggestion of a relation between secular marine $\delta^{34} \mathrm{~S}$ trends and sedex deposits (Sangster, 1968) has been noted by many subsequent studies (Goodfellow, 1987; Goodfellow and Jonasson, 1987; Goodfellow and Lydon, 2007; Johnson and others, 2009). More recently, a study of barite $\delta^{34} \mathrm{~S}$ and $\delta^{18} \mathrm{O}$ compositions in sedex deposits (Johnson and others, 2009) demonstrates the same systematics observed in modern barite mineralization that occurs at fluid seeps on modern continental margins. This comparative study established that $\mathrm{H}_{2} \mathrm{~S}$ is ultimately controlled by rates of bacterial sulfate reduction with organic matter, methane, and (or) possibly light hydrocarbons as the primary electron donor. The evidence that bacteria metabolize organic compounds to produce sulfide that precipitates the ore metals in local sedimentary environments highlights the importance of organic matter in the genesis of sedex deposits.

The importance of basinwide organic-rich metalliferous black shales in mineralized horizons has been widely noted (Turner, 1992; Large and others, 1998; Emsbo, 2004; Emsbo and others, 2005; Goodfellow and Lydon, 2007). The basinwide sequestration of organic carbon traditionally has been explained by the upwelling of cold, nutrient-rich ocean waters onto the continental shelf, causing a surge in bioproductivity and corresponding eutrophication or anoxic/dysoxic conditions. Alternatively, Emsbo and others (2005) proposed that hydrothermal basinal fluids themselves may have been the source of biolimiting nutrients that trigger the anoxic/dysoxic conditions that lead to organic carbon sequestration.

\section{Regional Environment}

\section{Geotectonic Environment}

Sedex Zn-Pb-Ag deposits occur in rift-generated sedimentary basins (Lydon, 1995; Leach and others, 2005b; Goodfellow and Lydon, 2007). Although rifting can occur in different tectonic settings - such as intracratonic regions (Mt. Isa-McArthur basins, Belt-Purcell basin), epicratonic passive continental margins (Selwyn basin, Brooks Range), and distal back-arcs (Rhenish basin) - all these types of sedexbearing basins share a common geologic architecture (fig. 3).

\section{Relations to Structures}

In his analysis of sedex deposit-hosting sedimentary basins, Large $(1980,1983)$ established a relation between sedex deposits and basin architecture. The relation, which has been verified by a host of subsequent studies (Large, 1980; Lydon, 1995; Kelley and others, 2004a; Large and others, 2005; Leach and others, 2005b; Goodfellow and Lydon, 2007), consists of the occurrence of sedex deposits in extensional, fault-bounded, first-order epicontinental and intracratonic basins that exceed about 100 kilometers $(\mathrm{km})$ in diameter. Within first-order basins, structurally controlled second-order basins, which are tens of kilometers in dimension, are controlled by halfgraben structures. Second-order basins are characterized by abrupt changes in sedimentary facies and isopachs and by the occurrence of intraformational debris flows and breccias. The graben-bounding faults served as conduits for hydrothermal brines travelling from underlying strata onto the sea floor to form the deposits. Third-order basins, which are a few kilometers in diameter, are bathymetric lows that represent euxinic, low-energy depositional environments dominated by organicrich, pyritic, fine-grained shale and mudstone. Third-order basins provide favorable locations for dense, bottom-hugging, metalliferous brines to accumulate and to react with locally derived $\mathrm{H}_{2} \mathrm{~S}$ to form sulfide ores.

\section{Relations to Sedimentary Rocks}

The stratigraphic evolution of sedex deposit-hosting rift basins can be divided into two phases (fig. 3). The rift phase is characterized by a 4 - to $15-\mathrm{km}$-thick accumulation of coarse continental clastic sediments, including conglomerates, red beds, sandstones, and turbidities, commonly with subordinate riftrelated volcanic successions. Thermal subsidence of basin margins, which is a natural consequence of late-stage continental rifting, causes a landward migration of shorelines and the deposition of shallow-water platform sediments that characterize the sag phase (Einsele, 2000). Sag-phase shallow-water carbonate and fine-grained clastic rocks (shales and siltstones) eventually transgress and cover rift-fill depocenters. With the exception of the Sullivan deposit (western Canada), sedex deposits are hosted in 1- to 4-km-thick sequences of fine-grained sag phase sediments. 


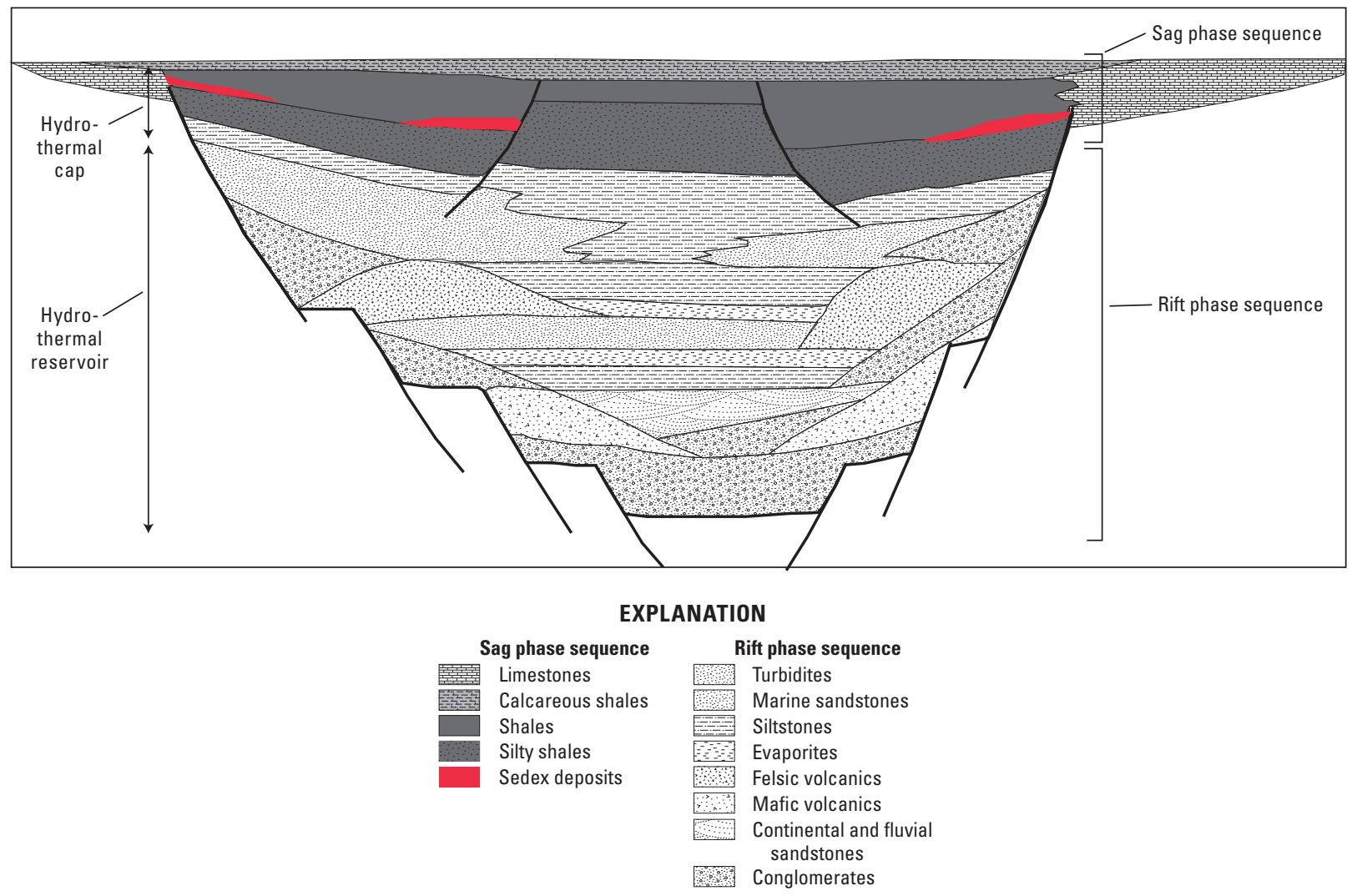

Figure 3. Schematic cross section through a rift-controlled sedimentary basin showing the idealized setting of sedex deposits. (Modified from Lydon, 2004a)

The host rocks for the ores are black shale, organic-rich siltstone, and calcareous mudstone. An identifying characteristic of sedex deposits is a high concentration of organic matter in ore horizons (Carne and Cathro, 1982). Laminated sulfide ores and strata on the periphery of shale-hosted sedex deposits generally contain between 3 and 10 percent total organic carbon (TOC) (Turner, 1992; Goodfellow and others, 1993; Large and Walcher, 1999; Large and others, 2005; Leach and others, 2005b; Goodfellow and Lydon, 2007; Feltrin, 2008). Leach and others (2005) noted a general relation between the size of sedex deposits and TOC contents and suggested that organic matter may be a factor in controlling deposit size. The regional enrichment of organic carbon in coeval sediments outboard from most sedex deposits, combined with high $\mathrm{S}: \mathrm{C}$ ratios of these sediments, the absence of benthic fauna, and the correspondence between ore formation and secular trends of $\delta^{34} \mathrm{~S}$ and $\delta^{13} \mathrm{C}$, has been used to argue that widespread, perhaps even global, anoxic conditions may be fundamental to the deposition and preservation of sedex deposits on the sea floor (Goodfellow, 1987; Turner, 1992; Goodfellow and others, 1993; Goodfellow and Lydon, 2007).

\section{Temporal (Secular) Relations}

Much has been written about the distribution of sedex deposits through time (Goodfellow and others, 1993; Lydon, 1995, 2004a; Goodfellow, 2004; Leach and others, 2005b). Sedex ores generally occur during two time periods in Earth history (fig. 4). The first period, in the Proterozoic (approx. 1.8 to 1.4 giga-annum [Ga]), is the most important in terms of contained metal and includes the deposits of the Mt. IsaMcArthur, Belt-Purcell, and Rajasthan basins. The second period (550 to 300 mega-annum [Ma]) includes the deposits of the Brooks Range and the Selwyn and Rhenish basins. The youngest known sedex deposits are Jurassic deposits in Pakistan and Cuba (Lydon, 2004a). Despite the larger amount of contained metal in the Proterozoic sedex period, there are no significant differences in grade, tonnage, and metal character between Proterozoic and Paleozoic deposits (Lydon, 2004b; Leach and others, 2005b).

The reasons for the bimodal age distribution of deposits are not entirely clear. The absence of deposits older than 1.8 Ga may be a consequence of highly reduced Fe and low sulfate, which suppressed $\mathrm{H}_{2} \mathrm{~S}$ in the Archean-Early Proterozoic anoxic oceans (Leach and others, 2005a; Lyons and others, 2006; Goodfellow and Lydon, 2007). Lydon (1997) suggests that prior to $1.8 \mathrm{Ga}$ there was a paucity of the large emergent continental areas needed to produce cratonic sedimentary basins with shallowwater shelf areas capable of producing evaporitic brines (Lydon, 1997; Bradley, 2008). Another possible explanation for the clustering of deposits in the Paleozoic, based on the correspondences between sedex deposits and global anoxic events, is that the sedex periods may reflect times when reducing conditions favored sulfide generation and the efficient precipitation and preservation of metal sulfides (Turner, 1992). 


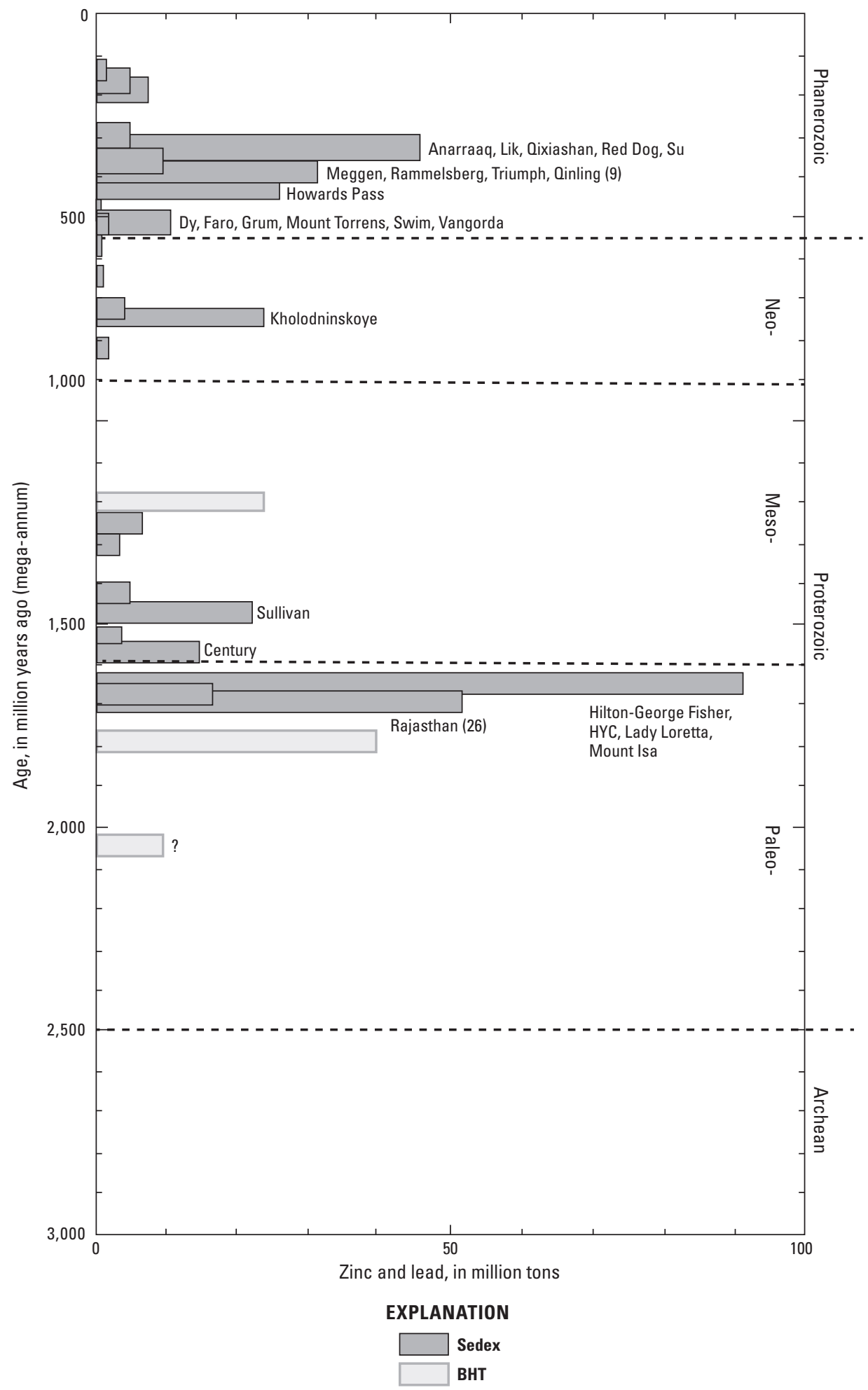

Figure 4. Distribution of contained lead and zinc $(\mathrm{Pb}+\mathrm{Zn})$ metal in known sedex deposits through time. Deposits are identified and plotted in age increments of 20 million years for their host rocks with significant deposits labeled. (Modified from Taylor and others, 2009) (BHT, Broken Hill type; HYC deposit now known as the McArthur deposit) 


\section{Duration of Hydrothermal System and (or) Mineralizing Processes}

A potentially important observation is that most of the major sedex deposit-hosting basins contain multiple episodes of mineralization. The Selwyn basin, one of the best studied examples, contains four distinct world-class sedex events and one smaller sedex barite event, all of which occurred during discrete time intervals during 150 million years of basin history (fig. 5) (Goodfellow, 2007). The Anvil district's seven deposits (fig. 6C) all formed during upper Middle Cambrian time, followed by the formation of at least 14 deposits and prospects in the Howards Pass district at the Llandovery-Wendlock boundary in Lower Silurian time (fig. 6A). Several deposits formed during two discrete time periods in the Upper Devonian: the Macmillan Pass district (fig. 6D) in middle Frasnian time and the Gataga district (fig. 6B) during upper Famennian time. The formation of small barite deposits in Lower Mississippian time was the final sedex event in Selwyn basin. Similarly, the Mt. Isa-McArthur basins host six of the world's largest sedex deposits hosted in four distinct and well-dated age horizons spanning more than 50 million years of Proterozoic time (fig. 7) (Large and others, 2005). Both the Rhenish and Rajasthan basins have two periods of mineralization separated by as much as 10 million years (Large and Walcher, 1999; Deb and Thorpe, 2001). In the Devonian Rhenish basin, formation of the Eifelian Rammelsberg deposit was followed by the late Givetian Meggen deposit (Large and Walcher, 1999). While the
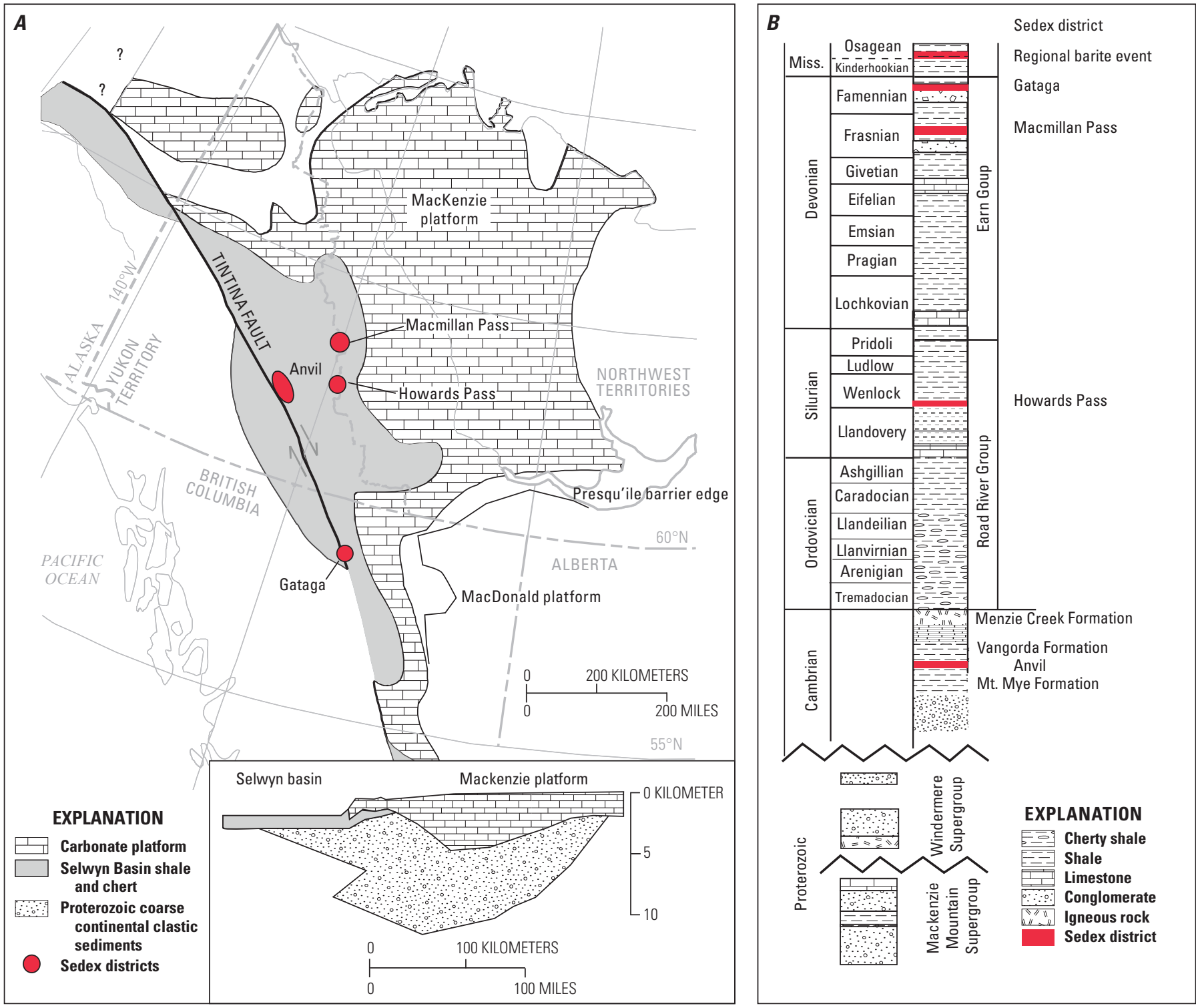

Figure 5. Geology of the Selwyn basin. $A$, Generalized paleogeographic map and generalized cross section (inset) of lower Paleozoic sedimentary architecture of Selwyn basin. (Modified from Abbott and others, 1986; Goodfellow, 2007) B, Schematic stratigraphic column of the Selwyn basin showing the age of sedex districts in the basin. (Modified from Abbott and others, 1986; Paradis and others, 1998) (Miss., Mississippian) 
age constraints are not as precise for deposits in the Proterozoic Rajasthan basin, the two distinctly mineralized horizons were likely deposited during a narrow time interval (Deb and Thorpe, 2001). In the Belt-Purcell basin, though the vast majority of mineralization is hosted in the Sullivan deposit in rocks of the lower Aldridge Formation, several smaller deposits are hosted in units of the middle Aldridge Formation (Lydon, 2004b).

Whereas mineralizing events in a basin can occur periodically during time periods of tens of millions of years or more, estimates of the duration of individual sedex-forming hydrothermal events, determined from paleontologic-sedimentologic constraints, range from 75,000 years to more than 1 million years (Goodfellow and others, 1993; Paradis and others, 1998). The most precise constraints on the duration are provided by paleontologic studies of the Gataga district in the Selwyn basin. The data indicate that $22 \mathrm{Zn}-\mathrm{Pb}-\mathrm{Ag}(\mathrm{Ba})$ and $\mathrm{Ba}$ deposits in the district formed during three discrete periods over an episode of approximately 7 million years in Upper Devonian time. Individual deposits such as the Driftpile deposit, however, may have formed solely within the lower to middle Palmatolepis marginifera conodont zone (Paradis and others, 1998), indicating that brine expulsion events in some areas likely lasted less than 500,000 years (Kaufmann, 2006). Even shorter time intervals are estimated from thermal modeling of brine systems, which suggests individual sedex deposits formed in less than 100,000 years (Appold and Garven, 2000; Garven and others, 2001; Yang and others, 2004, 2006; Cathles and Adams, 2005).

\section{Relations to Igneous Rocks}

Although the occurrence of rift-related volcanic rocks within some sedimentary successions would allow for some igneous contribution to ore metals (for example, Mt. Isa basin; Cooke and others, 1998), there is little evidence that igneous rocks are important for sedex ore formation. The apparent spatial relation between the Sullivan deposit and an underlying gabbroic sill in the Belt-Purcell basin appears to be one of ground preparation controlling later fluid flow (Lydon, 2004a). The emplacement of thick gabbroic sills into wet and unconsolidated sediments triggered mud volcanoes that caused massive brecciation and tourmalinization. These zones of altered and deformed sediments could have acted as fluid conduits that focused later brine migration, although it remains problematic that the age of all dated sills are younger than the deposit (Lydon, 2004a).

\section{Relations to Metamorphic Rocks}

Sedex deposits rarely show spatial, temporal, or genetic associations with metamorphic rocks. Post-ore metamorphism of sedex deposits is generally low grade (greenschist facies or below) with a few deposits attaining amphibolite grades (for example, Balmat, United States; Kholodninskoye, Russia; and Rampura-Agucha, India).

\section{Physical Description of Deposit}

\section{Dimensions in Plan View}

At the time of formation, sedex orebodies were deposited as stratabound and stratiform bodies with strike lengths of hundreds of meters to more than $1.5 \mathrm{~km}$ (figs. 6, 8, 9). Therefore, footprint dimensions of orebodies generally reflect post-sedimentation structural disruptions of ores. For example, the Century deposit is generally flat lying, with minor offsets along the Pandora fault and erosional terminations by the overlying Cambrian sequence, and attains dimensions in plan view in excess of $1.5 \mathrm{~km}$ (fig. $8 B$ ). In contrast, the steeply dipping Mount Isa, George Fisher, and Hilton deposits, while formed as laterally extensive deposits, are structurally tilted (fig. $8 A$ ) and therefore have a small footprint (approx. 250 meters [m]) in plan view. Because the original dimensions of sedex deposits can be large, it is important to consider that distinct orebodies in highly folded terrains may, in fact, have been formed as a single contiguous orebody.

It is also common for sedex districts to contain multiple deposits within the same stratigraphic interval and distributed along structures that extend tens of kilometers (figs. 6, 8, 9). For example, the Gataga district (fig. $6 B$ ) has six deposits in the same stratigraphic interval for $100 \mathrm{~km}$. Similarly, the Howards Pass district (fig. 6A) contains 14 named deposits over a strike length of $60 \mathrm{~km}$, the Anvil district (fig. $6 C$ ) contains 7 deposits over a strike length of $35 \mathrm{~km}$, and the 3 deposits of the Mt. Isa district (fig. $8 \mathrm{~A}$ ) occurs over $20 \mathrm{~km}$. Highly anomalous ore metal concentrations between deposits in an ore-hosting stratigraphic horizon demonstrate the enormous scale of these ore-forming systems.

\section{Vertical Extent}

Sedex orebodies are generally composed of stacked tabular lenses of stratiform sulfide ore that, when combined, are typically a few tens of meters thick (Large and others, 2005; Leach and others, 2005b). Feeder zones can extend for several hundred meters below vent proximal deposits, but they rarely contribute ore to the deposit, with the exception of Rammelsberg. For that reason, vertical extent, as with plan view dimensions, is primarily determined by post-ore structural disruptions of orebodies, which can give them vertical extents of hundreds of meters (figs. 6, 8, 9).

\section{Form/Shape}

Sedex deposits typically taper towards their margins for strike lengths of as much as $1.5 \mathrm{~km}$. Generally, aspect ratios of the orebodies (lateral extent divided by thickness) are more than 20 (Goodfellow and others, 1993; Lydon, 1995; Goodfellow and Lydon, 2007). Vent-proximal deposits (such as Tom, Jason, and Rammelsberg) generally have lower aspect ratios, which is thought to reflect the influence of vent hydrodynamics. Ventdistal deposits (such as Howards Pass, McArthur River (HYC), Century, and Meggen) have higher ratios, which is believed to reflect the morphology/bathymetry of the basin lows in which 
A Howards Pass district

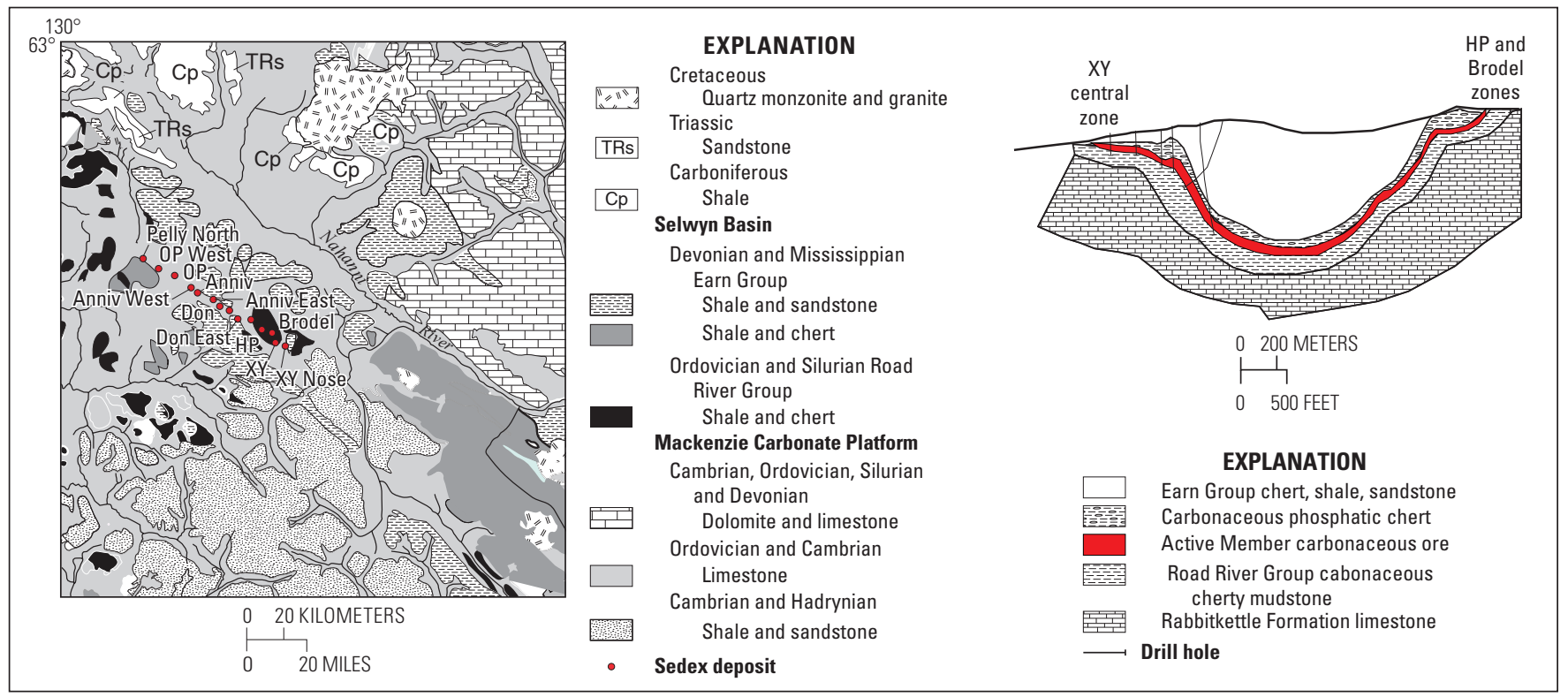

B Gataga district

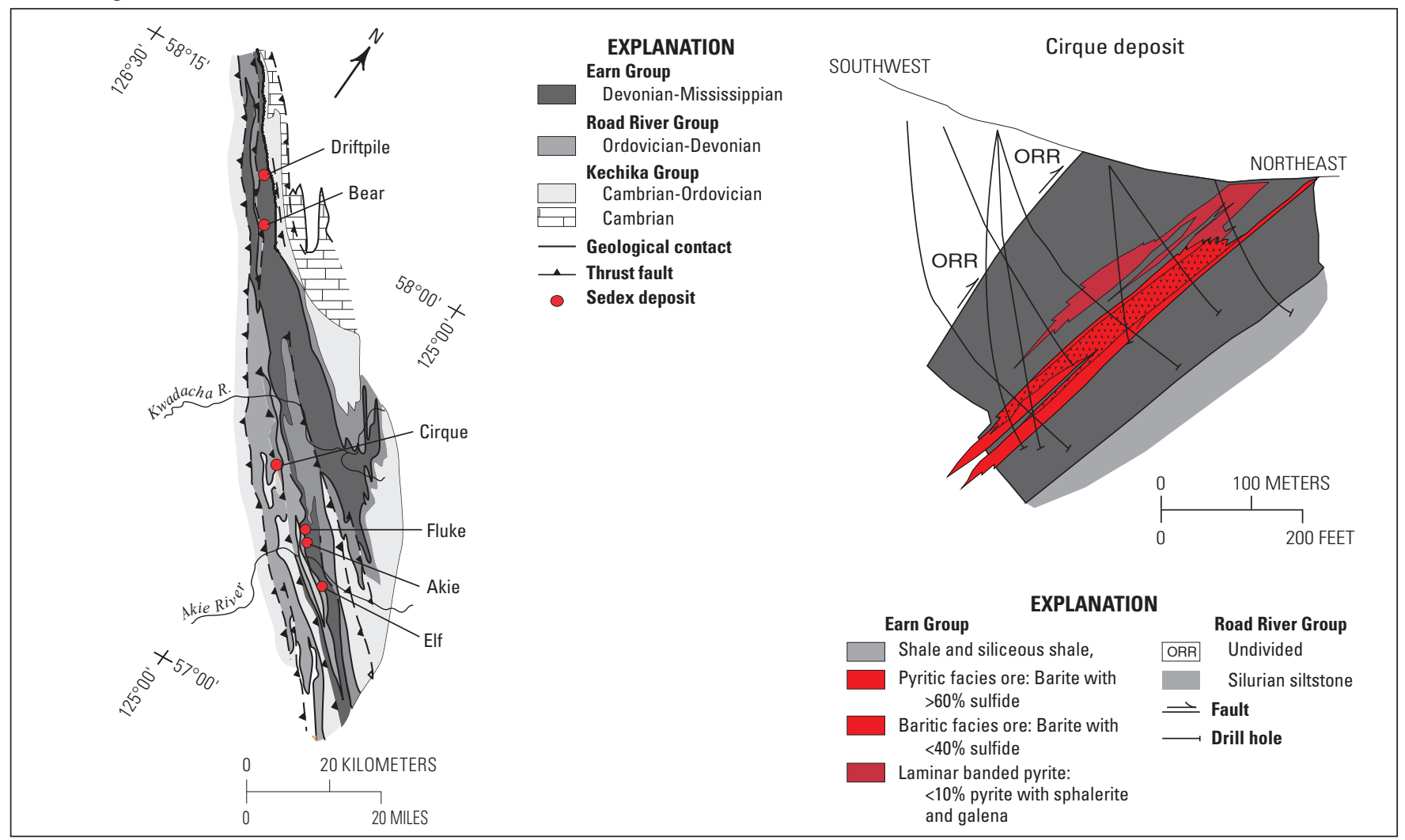

Figure 6. Generalized geologic maps of the major sedex mining districts of the Selwyn basin. See figure 5 for a location map and general stratigraphic position of the districts. $A$, Geologic map and location of deposits of the Silurian Howards Pass district (after Goodfellow, 2007) and a schematic section between the XY and HP deposits (modified from www.selwynresources.com, accessed September 30, 2012). $B$, Regional geology of the Kechika Trough showing the location of Late Devonian sedex deposits of the Gataga district (modified from Goodfellow, 2007) and a section through the Cirque deposit, the largest in the district (modified from Pigage, 1986). C, Generalized geology and location of deposits of the Anvil district (modified from Goodfellow, 2007) and a section of the Faro deposit (modified from Jennings and Jilson, 1986). D, Geology of Macmillan Pass district showing the location of sedex deposits (modified from Goodfellow, 2007; Bailes and others, 1987) and the geology of the Tom-Jason subbasin (modified from McClay and Bidwell, 1987). See figure 9D for a section through the Jason deposit. (\%, percent; Zn, zinc; Pb, lead) 


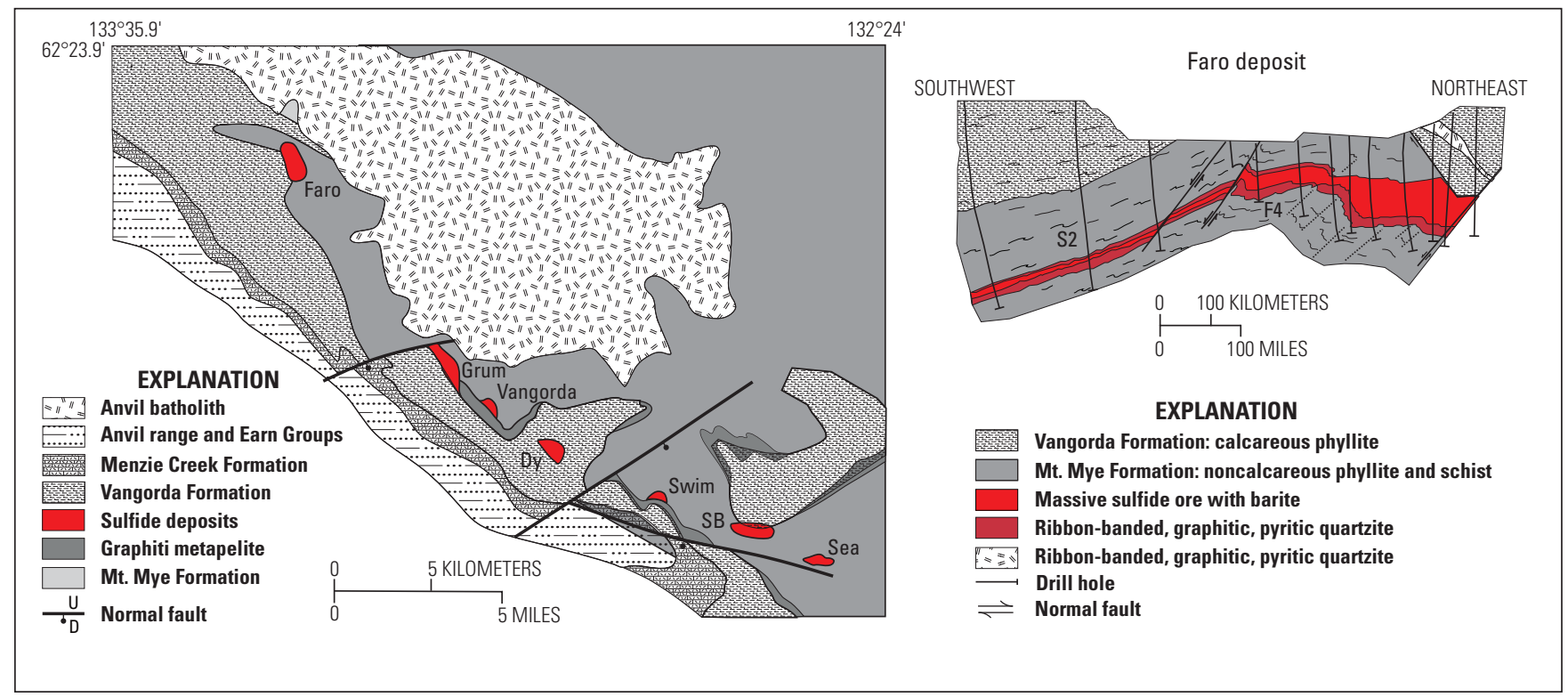

\section{Macmillan Pass district}

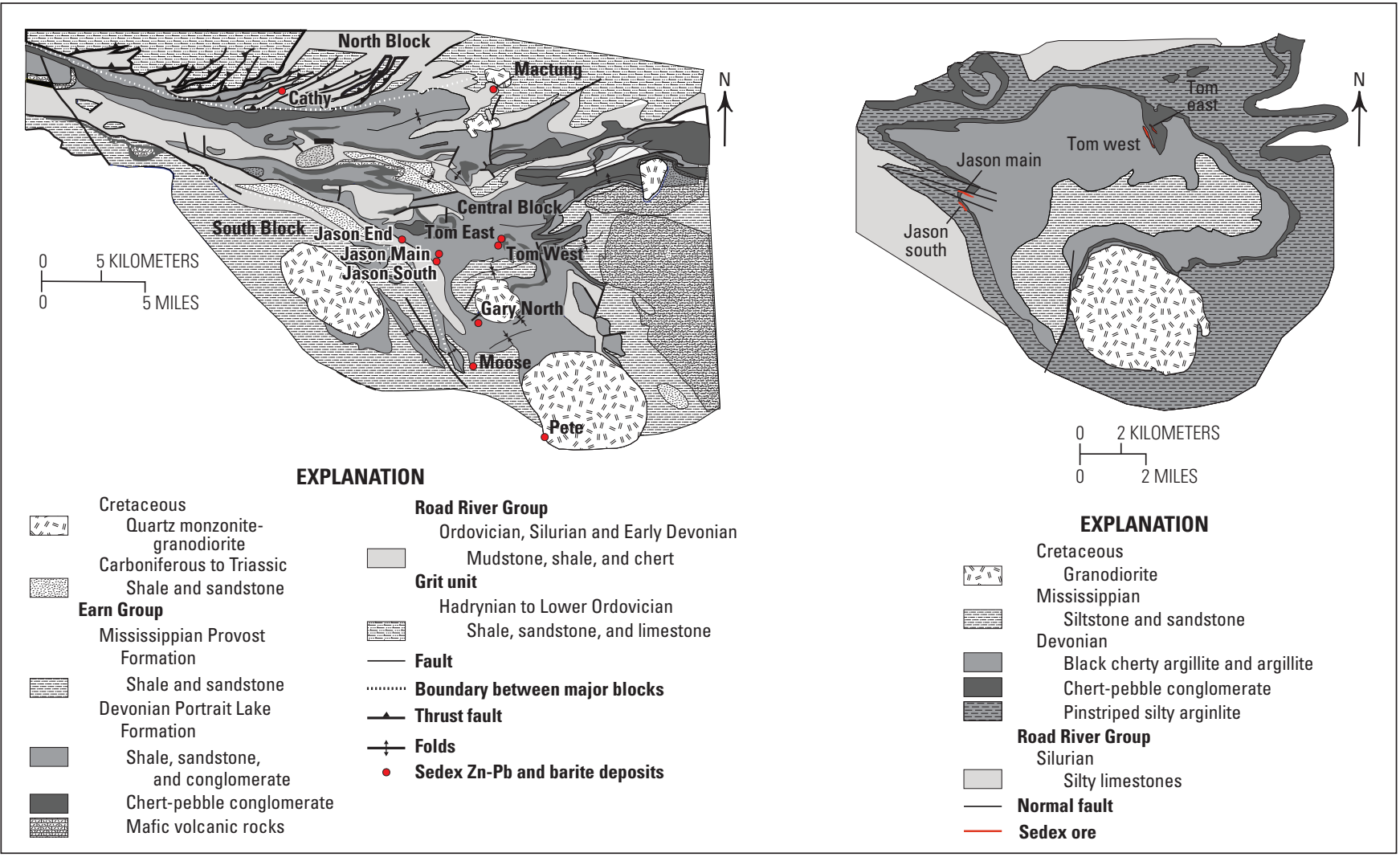

Figure 6. Generalized geologic maps of the major sedex mining districts of the Selwyn basin. See figure 5 for a location map and general stratigraphic position of the districts. A, Geologic map and location of deposits of the Silurian Howards Pass district (after Goodfellow, 2007) and a schematic section between the XY and HP deposits (modified from www.selwynresources.com, accessed September 30, 2012). $B$, Regional geology of the Kechika Trough showing the location of Late Devonian sedex deposits of the Gataga district (modified from Goodfellow, 2007) and a section through the Cirque deposit, the largest in the district (modified from Pigage, 1986). C, Generalized geology and location of deposits of the Anvil district (modified from Goodfellow, 2007) and a section of the Faro deposit (modified from Jennings and Jilson, 1986). D, Geology of Macmillan Pass district showing the location of sedex deposits (modified from Goodfellow, 2007; Bailes and others, 1987) and the geology of the Tom-Jason subbasin (modified from McClay and Bidwell, 1987). See figure $9 D$ for a section through the Jason deposit. (\%, percent; Zn, zinc; Pb, lead) 

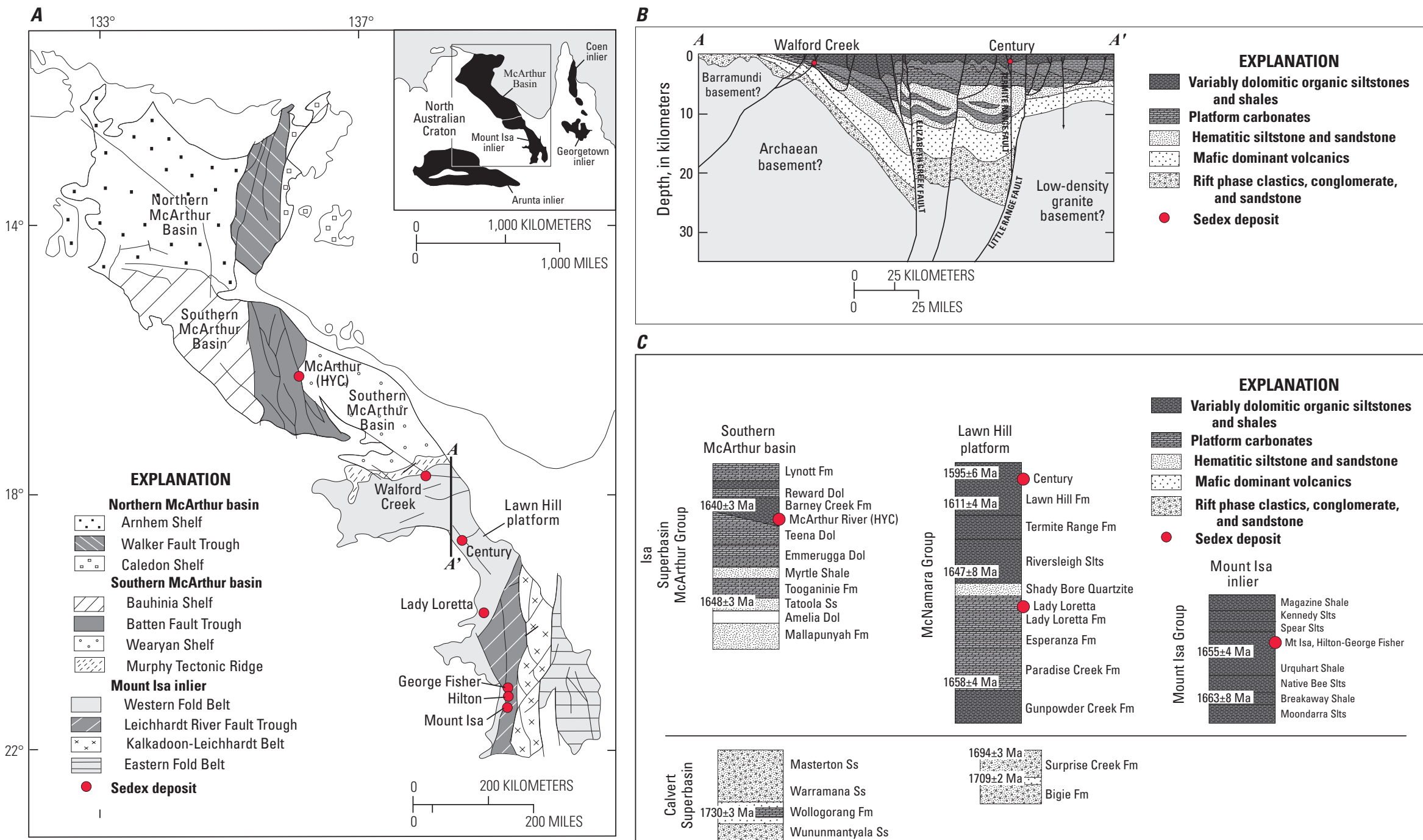

$c$

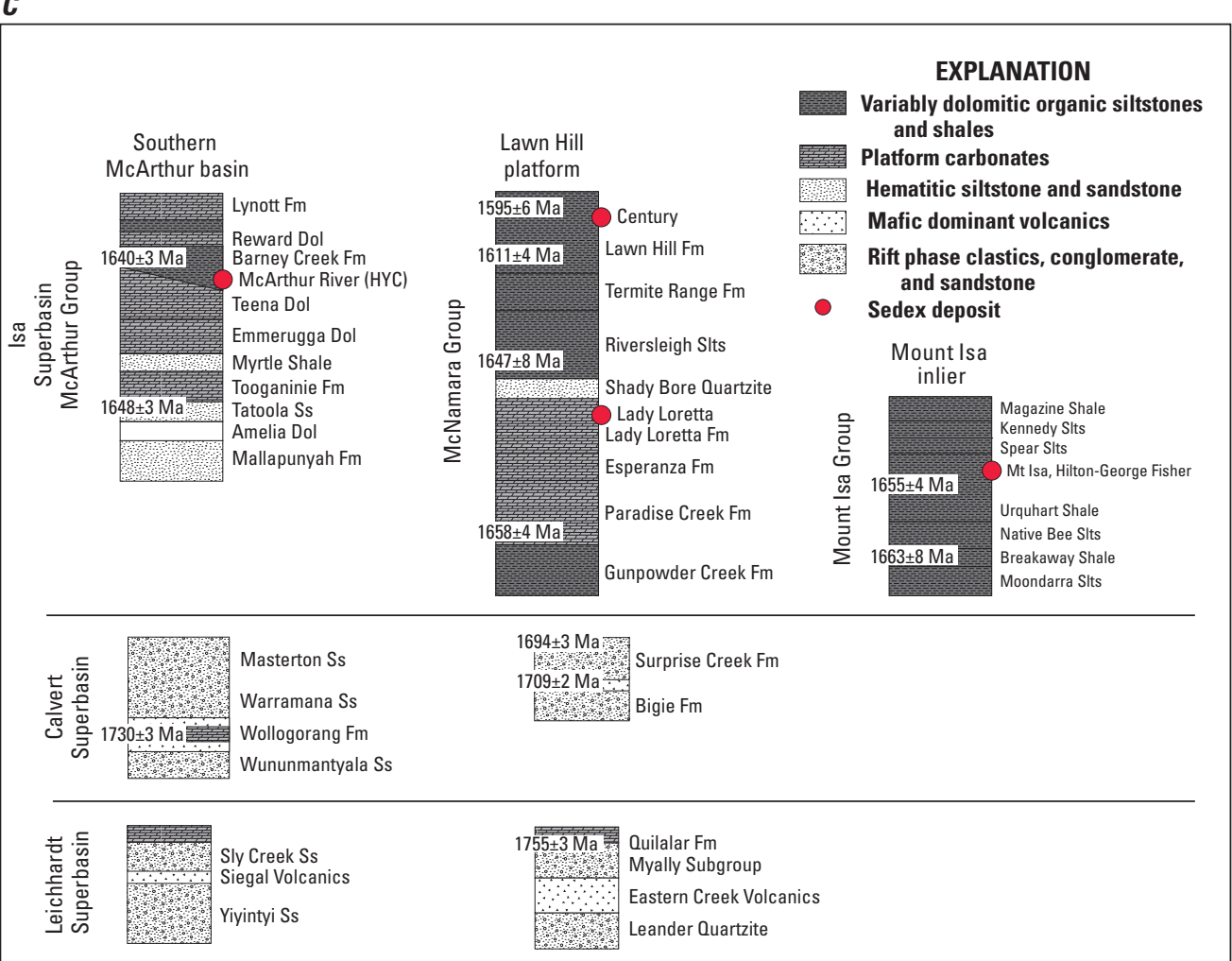

Figure 7. Geology of the Mt. Isa-McArthur basins. A, Simplified geologic map of the basins of northern Australia showing the location of major tectonic elements and the position of sedex deposits. Inset shows the outcrop distribution of major geological provinces of the North Australian craton. (Modified from Betts and others, 2003) $B$, Geologic cross section along transect $A-A^{\prime}$. Only supersequence-level stratigraphy and large simplified structures are shown. (Modified from Southgate and others, 2006) $C$, Schematic comparative stratigraphy of the Mt. Isa-McArthur basins showing the stratigraphic position and age of the major sedex deposits in the basin. (Modified from Large and others, 2005) (Fm, Formation; Dol, Dolomite; Ss, Sandstone; Slts, Siltstone; Ma, mega-annum) 
ore-forming brines could accumulate and deposit their metals (Lydon, 1995; Sangster, 2002; Ireland and others, 2004). Lydon $(1995,2004 a)$ distinguished four facies on the basis of morphology (fig. 10). Feeder zones can extend for several hundred meters below vent-proximal deposits, but they rarely contain orebodies. Vent-complex facies above the feeder zones are characterized by massive to weakly bedded massive sulfide ores and are commonly the thickest and highest grade parts of orebodies. Bedded ore facies occur tens to hundreds of meters distal to the vent complexes in vent-proximal deposits and are the sole ore type in vent-distal deposits. This facies contains compositionally layered sulfides interbedded with shales, siltstones, and fragmental sedimentary rocks. Bedded ores taper in thickness along strike and become lower in grade until they become subeconomic. The distal hydrothermal facies represent the outward continuation of the mineralized horizon beyond the economic bedded ores. The economic ore represents a small fraction of the total sulfide in a deposit. A slight decrease in the cutoff grade (approx. 1 percent combined $\mathrm{Zn}-\mathrm{Pb}$ ) in the Tom deposit, for example, would increase the ore reserves by a factor of 5 (Goodfellow and others, 1993), and inclusion of sulfide in the distal hydrothermal facies would significantly increase this estimate further.

\section{Host Rocks}

Orebodies comprise as many as 15 individual ore lenses that are separated by pyritic, organic-rich shales, siltstones, and (at some localities) debris flows. Host rocks of sedex deposits are fine-grained marine sedimentary rocks that include carbonaceous (3-10 percent TOC) shale and chert (Howards Pass and Red Dog), dolomitic shale or siltstone (McArthur River [HYC] and Mount Isa), and micritic limestone (Meggen) (Leach and others, 2005b; Goodfellow and Lydon, 2007). Turbidities and slump breccias are common within the ore-hosting sequences at a number of deposits, including Meggen and Rammelsberg, Jason and Tom, Faro, and McArthur River (HYC). Minor bentonite beds are present within the ore-hosting sequences at a number of deposits, including Meggen, Rammelsberg, Jason, Faro, and McArthur River (HYC). Distal hydrothermal facies on the fringes of orebodies are typically organic- and sulfide-rich black shales, cherts, and siltstones. Many deposits have been metamorphosed and deformed along with their host rocks (for example, Sullivan and Mount Isa).

\section{Structural Setting and Controls}

It is well established that sedex deposits are associated with long-lived regional fault systems that control the development of first- and second-order basins. Deposits and districts are typically oriented along second-order faults that control halfgraben depositional centers. The longevity of these deep-rooted faults, which is apparent from their long-term influence on basin configuration and sedimentary facies, reflects a history of reactivation (Large and others, 2002; Emsbo and others, 2006). Most deposits show a direct relation between fault movement and ore formation. Fault movement is expressed as growth faults with associated rapid sedimentary facies changes, periodic influx of coarse breccias and debris flows from fault scarps, synsedimentary slumping, stratigraphic thickening toward subsiding basin margins, and foundering of basin environments. Inferred structural regimes include normal extensional faults, orthogonal transform faults, and wrench faults with transpressional and transtensional segments (Emsbo and others, 1999; Large and others, 2002; Goodfellow and Lydon, 2007). Finally, the association of sedex deposits with post-ore thrust faults in tectonically disrupted strata reflects inversion of the basin by reverse movement on original normal faults (for example, Emsbo and others, 2006).

\section{Geophysical Characteristics}

\section{Magnetic Signature}

Magnetic field anomalies may be used to distinguish different rock types by indicating lateral variations in minerals that have strong magnetic properties, such as magnetite, hematite, and titanomagnetite, as well as iron-bearing sulfides such as pyrrhotite and greigite. For deposits associated with such minerals, the magnetic field can provide a direct means for exploration, but sedex deposits typically are not associated with these minerals, and magnetic signatures may be subtle, if present at all. The magnetic field can be used, however, to facilitate geologic mapping, particularly structural trends and the presence of volcanic or sedimentary rocks. The ease and relatively low cost of collecting magnetic field data make such data important for regional assessments for sedex deposits. Because magnetic field anomalies represent properties integrated over depth, additional constraints from geological observations, as well as seismic, well log, and other geophysical techniques, are a critical component of interpretation of magnetic data. Detailed descriptions of magnetic properties relevant to exploration, mainly susceptibility and remnant magnetization, are given by Hoover and others (1992) and Ford and others (2007).

High-resolution studies have yielded magnetic field anomalies near deposits (Brock, 1973). Larger scale studies can be used not only for discerning different rock types, but also for discerning different terranes and the faults that bound them. For sedex deposits, magnetic lineations are particularly useful for identifying faults that may have acted as fluid conduits, such as those mapped near the Belt basin in Montana (Sims and others, 2004), within the Belt-Purcell basin (Lowe and others, 2001), near the Mount Isa deposit (Betts and others, 2004), and near the Central Midlands basin in Ireland (Williams and Brown, 1986). Magnetic depth-to-source methods can be used to delineate large basins required for sedex formation, as sediments that fill these basins generally have much weaker magnetic properties than the underlying crystalline rock. 


\section{A Mount Isa, Hilton, George Fisher deposits}

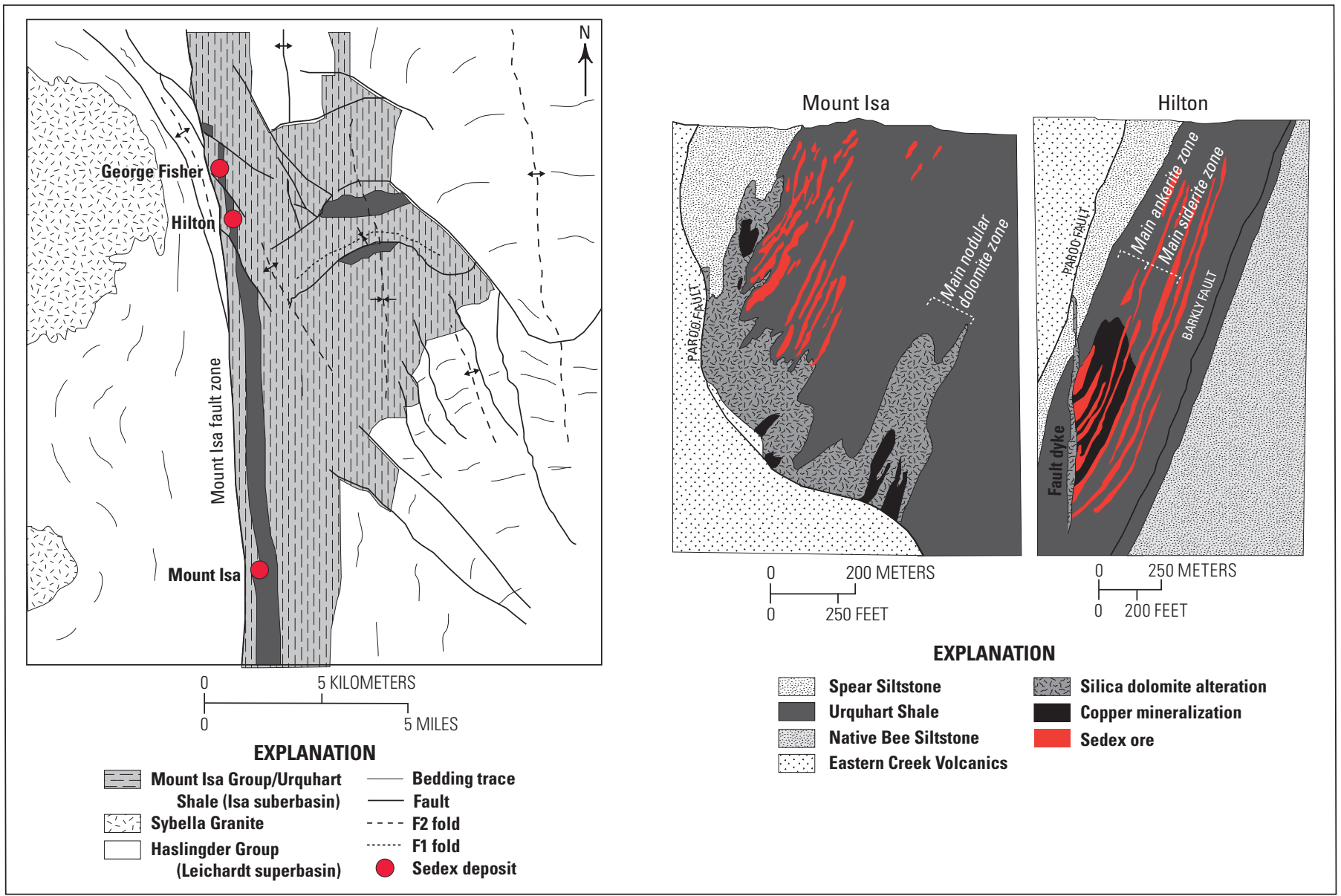

Figure 8. Generalized geologic maps of the major sedex mining districts of the Mt. Isa-McArthur basins. See figure 7 for a location map and general stratigraphic position of the districts. $A$, Geologic map of the Isa Valley showing the structural position of the Mount Isa, Hilton, and George Fisher deposits (modified from Betts and Lister, 2001) and a geologic cross section of the Mount Isa and Hilton deposits (modified from Large and others, 2005). $B$, Structural setting of the Century deposit showing the spatial association with the intersection of the Termite Range fault and an inferred northeast-striking normal fault (after Betts and others, 2003) and a geologic cross section and stratigraphic column of ore and downhole metal distribution at Century (modified from Large and others, 2005). $C$, Simplified geologic map of the fault architecture in the region around the McArthur (HYC) deposit and a schematic cross section showing the relation between fault architecture, stratigraphy, and the McArthur (HYC) deposit (modified from Betts and others, 2003). (\%, percent; ppm, parts per million; Zn, zinc; $P$, phosphorus; $T$, thallium; C, carbon; 0 , oxygen) 
B Century deposit

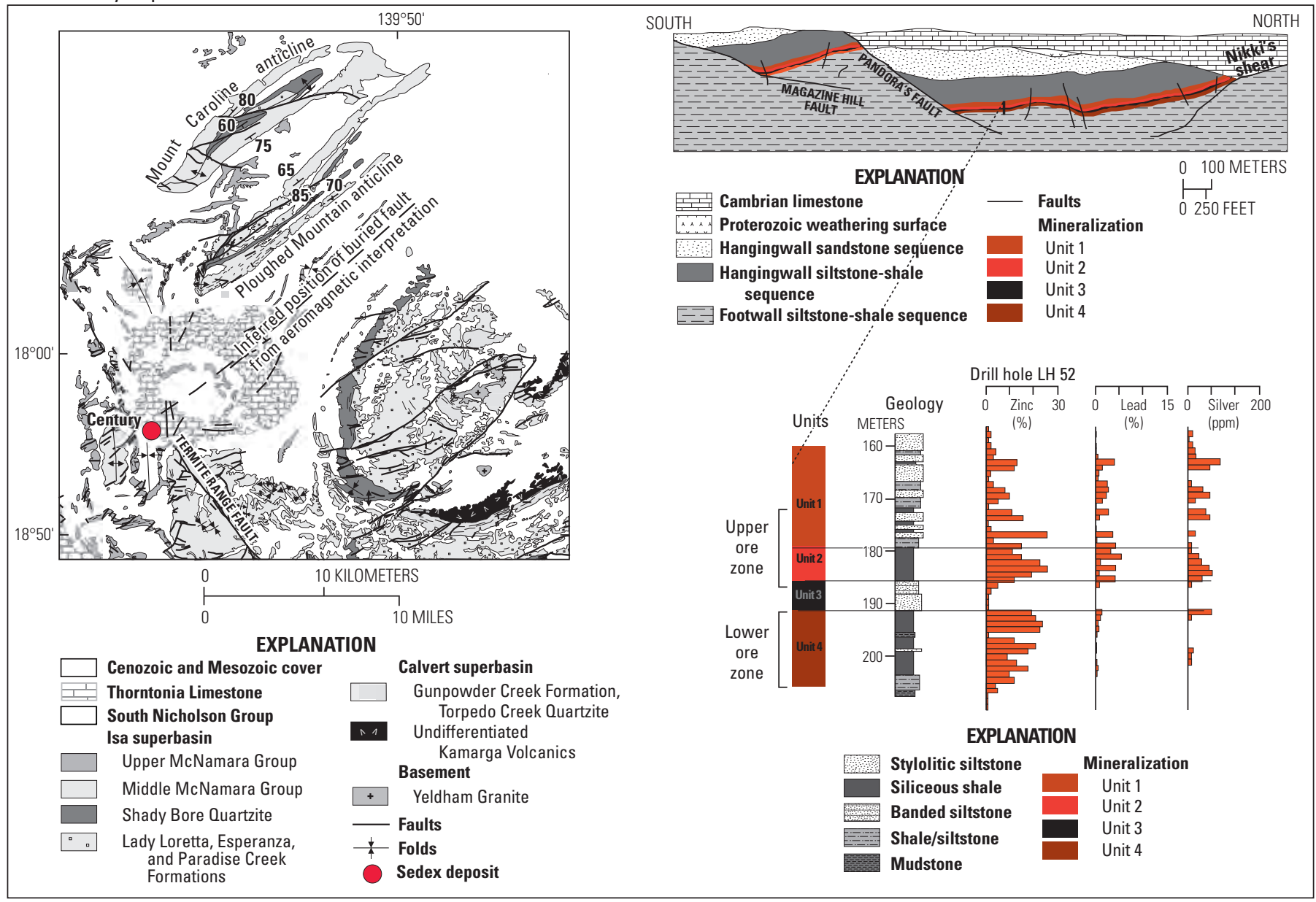

C McArthur River (HYC) deposit

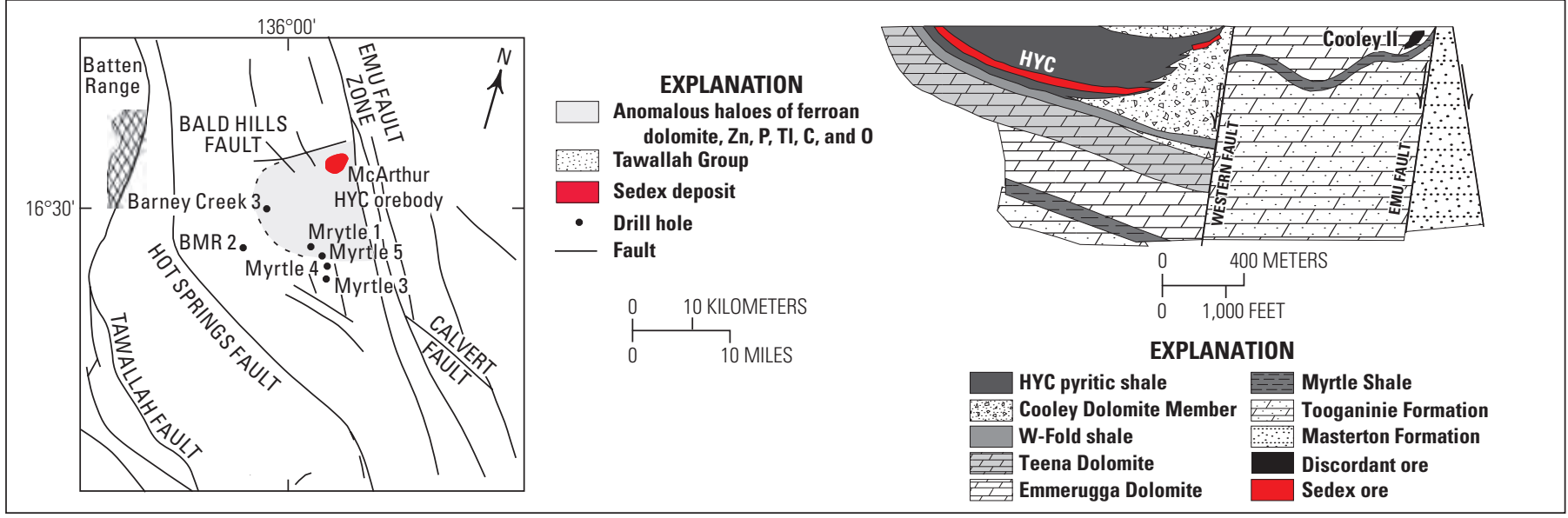

Figure 8. Generalized geologic maps of the major sedex mining districts of the Mt. Isa-McArthur basins. See figure 7 for a location map and general stratigraphic position of the districts. $A$, Geologic map of the Isa Valley showing the structural position of the Mount Isa, Hilton, and George Fisher deposits (modified from Betts and Lister, 2001) and a geologic cross section of the Mount Isa and Hilton deposits (modified from Large and others, 2005). $B$, Structural setting of the Century deposit showing the spatial association with the intersection of the Termite Range fault and an inferred northeast-striking normal fault (after Betts and others, 2003) and a geologic cross section and stratigraphic column of ore and downhole metal distribution at Century (modified from Large and others, 2005). $C$, Simplified geologic map of the fault architecture in the region around the McArthur (HYC) deposit and a schematic cross section showing the relation between fault architecture, stratigraphy, and the McArthur (HYC) deposit (modified from Betts and others, 2003). (m, meter; \%, percent; ppm, parts per million; Zn, zinc; Pb, lead; TI, thallium; C, carbon; 0, oxygen)_Continued 
A Aqqaluk deposit (Red Dog deposit)

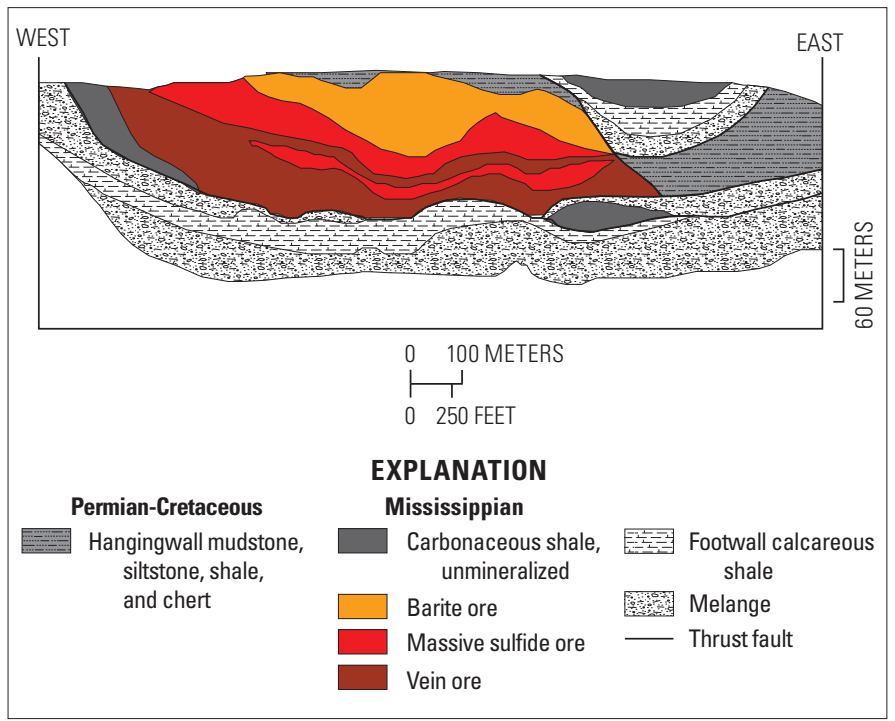

C Sullivan deposit

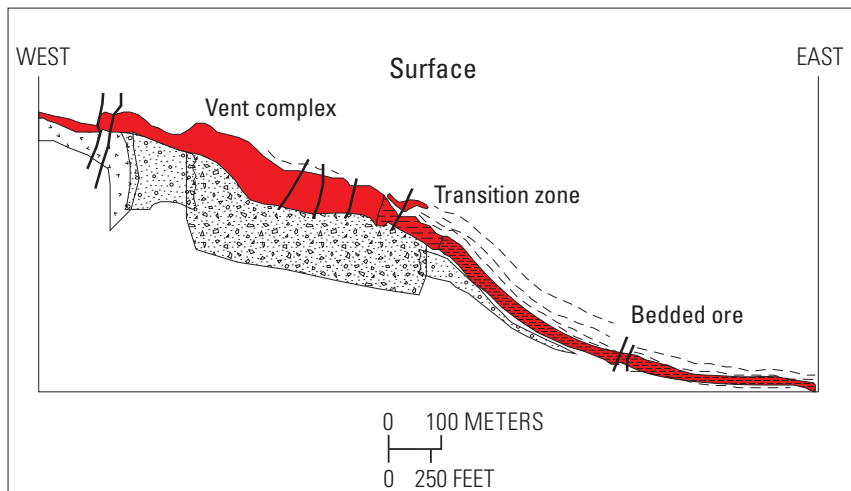

EXPLANATION

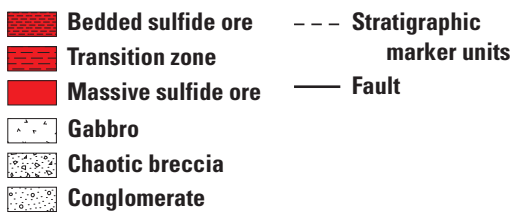

B Anarraaq deposit
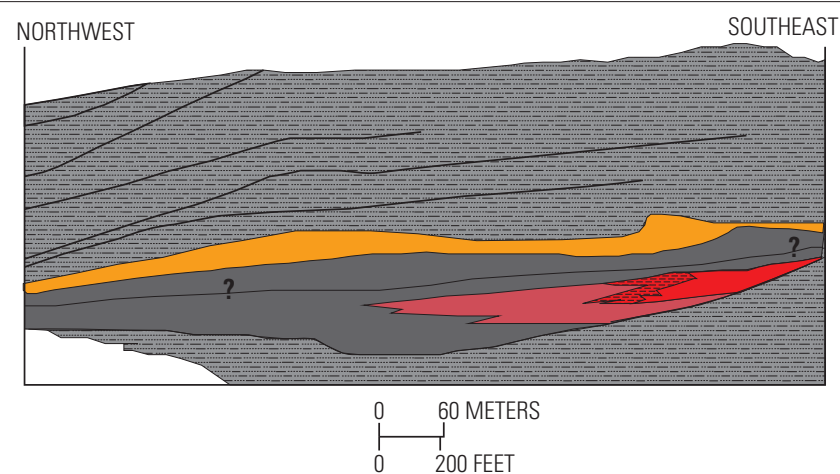

EXPLANATION

Permian-Triassic Mississippian

Hangingwall shale

Barite

Carbonaceous shale,

unmineralized

Massive sulfide ore

\section{Jason deposit}

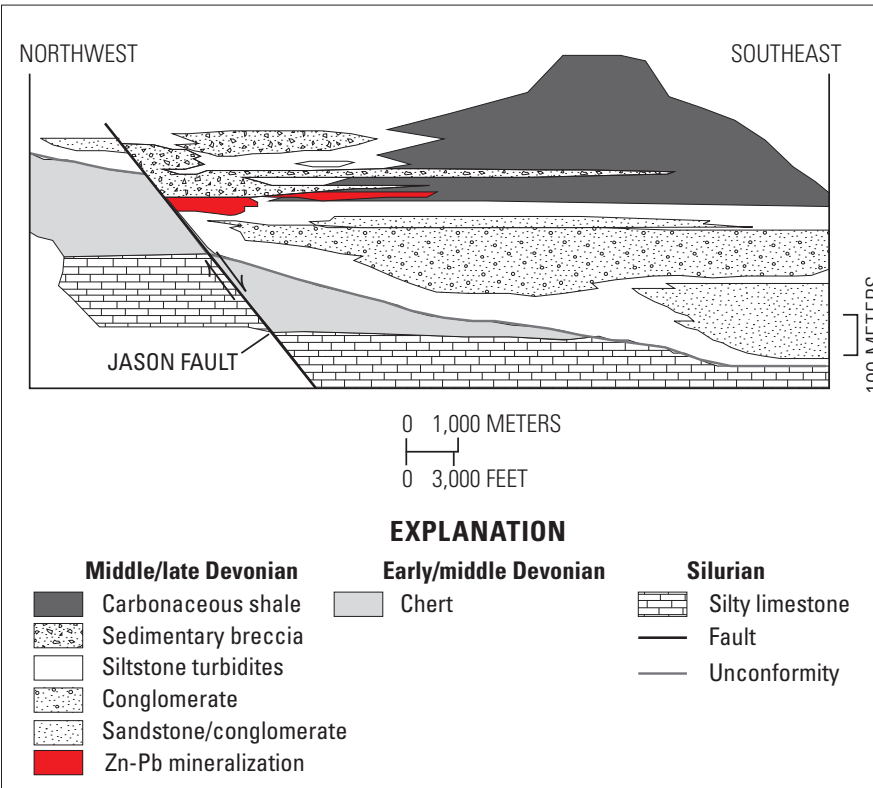

Figure 9. Generalized cross sections showing the structural setting, stratigraphic position, and morphology of other sedex deposits. $A$, Red Dog deposit, Brooks Range, Alaska, United States. $B$, Anarraaq deposit, Brooks Range, Alaska, United States. $C$, Sullivan deposit, Belt-Purcell basin, United States and Canada. D, Jason deposit, Selwyn basin, Canada. (Modified from Leach and others, 2005b) (Fe, iron; Zn, zinc; Pb, lead) 


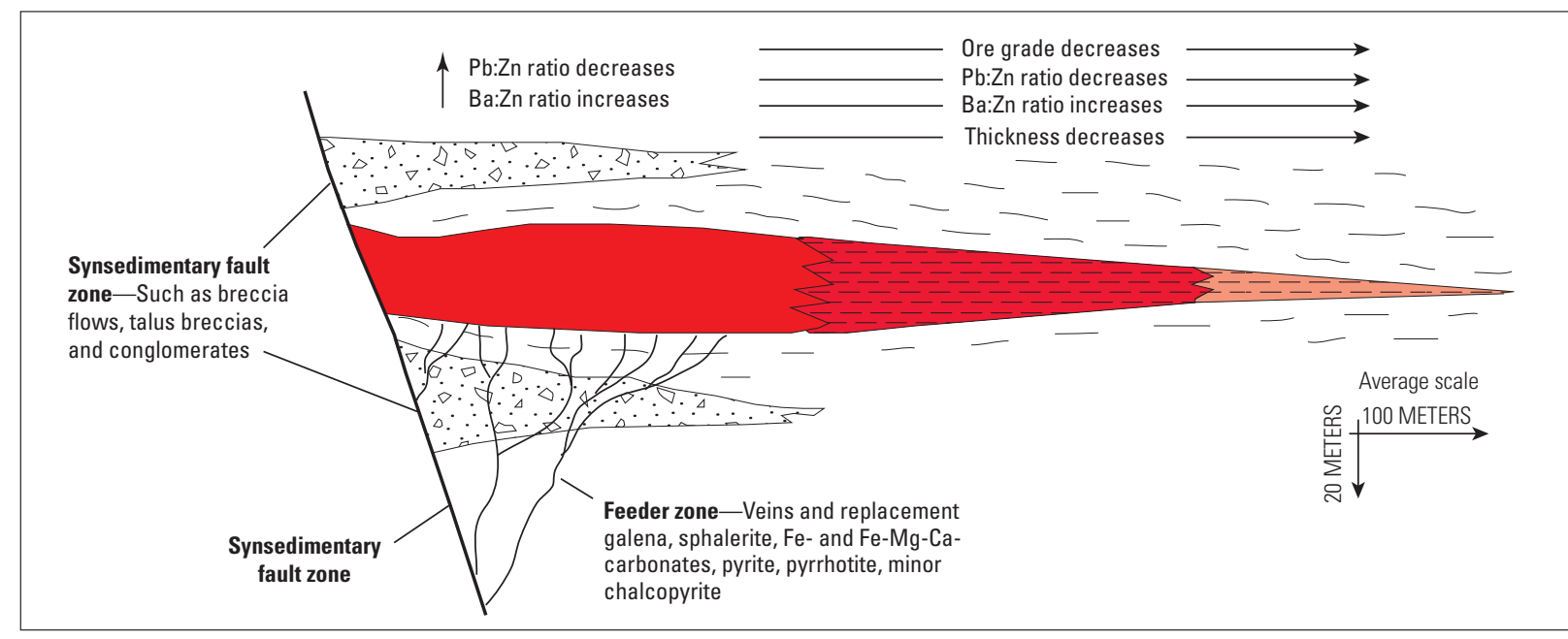

\section{EXPLANATION}

Vent complex - Massive, brecciated, crudely bedded pyrite, galena, sphalerite, $\mathrm{Fe}-$ and $\mathrm{Fe}-\mathrm{Mg}$-Ca-carbonates, barite (at top) \pm pyrrhotite, sulphosalt

Bedded ores-Laminated and occasionally fragmented pyrite, sphalerite, galena, chert, barite, $\mathrm{Fe}-\mathrm{Mg}$-carbonates \pm beds of host lithologies

Distal hydrothermal products - Chert, barite \pm minor sphalerite, pyrite, $\mathrm{Ca}-\mathrm{Mg}$ carbonates, magnetite, hematite, Mn enrichment

Figure 10. Cross section showing morphology and distribution of ore types and mineralogic and geochemical zoning through an idealized sedex deposit. (Modified from Lydon, 2004a) (Fe, iron; Mg, magnesium; Ca, calcium; Pb, lead; Zn, zinc; Ba, barium; Mn, manganese)

\section{Gravity Signature}

Gravity anomalies indicate variations in rock density integrated over depth. While VMS and barite deposits can be detected directly using gravity data if station coverage is dense enough, sedex deposits often exhibit a more subtle signature, if any can be detected at all. As with magnetic field data, gravity data more generally can be used to aid regional geologic characterization through the delineation of basin or terrane boundaries, faults, basement depth, and basement structure/lithology. Depending on data coverage, gravity data can be used for the delineation of dense bodies such as massive sulfide and barite within sedimentary units. Gravity data are more expensive to acquire compared to magnetic field data, and the data are more readily available for individual stations rather than on a grid because of the particularly high expense of airborne gravimetry. There is currently good station coverage over the conterminous United States to facilitate studies on scales of hundreds of kilometers, but coverage at finer scales varies substantially. As with magnetic field data, gravity data interpretations are most definitive when combined with independent constraints, such as geologic observations and (or) other geophysical data that include seismic or well log measurements. Detailed descriptions of rock density properties relevant to mineral exploration are given by Hoover and others (1992) and Ford and others (2007).

Faults, terrane boundaries, and basins may be delineated by highlighting density contrasts at depth. In particular, basins that are filled with sediments and bounded by denser basement rock may exhibit a corresponding gravity low over the less dense sediments. Some basins, however, are associated with gravity highs because of the presence of dense volcanic materials (for example, the Midcontinental Rift basin). Other basins, such as the Michigan and Illinois basins, do not show any clear correlation with gravity data because (1) complex cratonic history often generates heterogeneities within the basement that dominate the gravity signal, (2) some basins are filled with carbonate or other high-density sedimentary rock whose density may approach that of the surrounding basement, and (3) some broader basins may actually be in isostatic equilibrium and, without a topographic expression, this equilibrium would not be taken into account in the isostatic residual.

Gravity has been used for geologic characterization of sedex deposit areas at sites such as the Century deposit (Murphy and others, 2008), the Faro deposit (Brock, 1973), and the Meggen and Rammelsberg deposits (Werner, 1989). Gravity measurements have similarly been used on Irish-type deposits in the Central Midlands basin of Ireland (Williams and Brown, 1986). In particular, a detailed survey over the Mount Isa orebody found gravity lows associated with oxidation along a fault and a gravity high associated with silica dolomite alteration with some contribution from $\mathrm{Zn}-\mathrm{Pb}-\mathrm{Ag}$ mineralization (Fallon and Busuttil, 1992). An extensive evaluation of geophysical methods at the Red Dog deposit determined that gravity was most effective in delineating the dense sulfide+barite ore. Subsequent use of gravity surveys in the district represents one of the most successful examples of the use of geophysics in sedex exploration. Combined with geologic mapping and geochemistry, these surveys led to the discovery of the Anarraaq deposit and several extensions of the Red Dog deposit, doubling its reserves (Kelley and Jennings, 2004). 


\section{Electrical Signature}

Electrical methods measure contrasts in the conductivity of Earth materials, with a variety of methods used to achieve different lateral and depth resolutions and sensitivities. Conductivity properties of given materials can vary by several orders of magnitude, making interpretation challenging (see Hoover and others, 1992, and Ford and others, 2007, for detailed descriptions). Nonetheless, the materials with the highest conductivities tend to be metals/massive sulfide, graphite, and higher porosity sediments, particularly if saltwater is present. Igneous and metamorphic rocks generally have low conductivities, but altered and weathered rocks exhibit intermediate values, as do sediments with high freshwater concentrations. Conductivity values of shales and clays vary widely. Electrical methods have a number of uses for mineral exploration, and the detection of sulfides, shales, and graphite is directly relevant to sedex assessment. Conductivity structure can also be used to support geologic mapping. Regrettably, electrical methods, which are mostly conducted on the ground, are typically complex and significantly more expensive to implement than magnetic and gravity surveys.

Known sulfides and alteration mineralization have been imaged using electrical methods at the Sullivan deposit (Wynn and others, 1977; Lowe and others, 2001), and downhole electromagnetic surveys showing responses directly attributable to orebodies have been done at the Mount Isa deposit (Fallon and Busuttil, 1992). Magnetotellurics have been used to support geologic mapping in the vicinity of the Century deposit (for example, Mutton, 1997; Murphy and others, 2008) but not at the deposit itself. The deposit was instead imaged using induced polarization (Hawke and Booker, 2001), which showed a response to either galena or perhaps sphalerite combined with an absence of more conductive sulfide minerals. Similarly, an extensive evaluation of the Red Dog deposit led to the determination that the most reliable electrical method for detecting sulfides was induced polarization (Kelley and Jennings, 2004). In general, however, low contrast in conductivity between ore sulfides and the carbonaceous shale or mudstone that host the deposits make any electromagnetic response difficult to recognize (Kelley and Jennings, 2004).

\section{Radiometric Signature}

Gamma-ray scintillation spectrometry can be used to detect abundances of radioactive elements within roughly 20-60 centimeters $(\mathrm{cm})$ of the Earth's surface. Elements of interest are naturally occurring potassium (K), thorium (Th), and uranium (U), which are the most abundant of the radioactive elements. While these elements are not directly indicative of sedex deposits, they can be used to assist geological characterization. In particular, potassium enrichment accompanying sericitic alteration may indicate sedex deposition. Additional uses include correlating data with surface geologic maps of units that have particularly high concentrations of radioactive elements. Airborne radiometric data were collected over the conterminous United States and Alaska during the National Uranium Resource Evaluation (NURE) surveys of the 1970s with track spacing of one to several kilometers. Data have been cleaned, leveled, and gridded by the U.S. Geological Survey at corresponding resolutions (Duval and others, 2005) and are available on disc and online. Processed flight line data, however, required for mapping at scales of less than a few kilometers, are not available.

Radiometric data also reflect outcrop, land use, and vegetation patterns and are influenced by topography reflecting the distance between source and sensor. Elemental ratios are therefore more frequently diagnostic of chemical domains that are relevant to mineral exploration. Elevated levels of potassium and relatively depleted levels of thorium have been observed at the Sullivan deposit (Lowe and others, 2001), but other areas, such as the Mount Isa deposit, do not exhibit significantly enhanced potassium (Fallon and Busuttil, 1992).

\section{Hypogene Ore/Gangue Characteristics}

\section{Mineralogy}

Sedex ores are mixtures of hydrothermal chemical precipitates and clastic and biogenic sediments, which, in some cases, are complicated by the sub-sea-floor hydrothermal replacement of sediment (fig. 11). Iron sulfide is

Figure 11 (facing page). Photographs of samples illustrating the diversity of textures and mineralogic and geochemical composition of sedex ores. Location boxes on each hand sample indicate the scanning micro $\mathrm{x}$-ray fluorescence concentration maps of selected elements. $A$, Laminated baritic carbonaceous bedded ore from the Tom deposit, Canada, showing the chemical expression of fine laminae of sphalerite $(\mathrm{Zn})$, barite $(\mathrm{Ba})$, and pyrite $(\mathrm{Fe})$ interbedded with shale layers (proxy by the Si map). $B$, Finely laminated highgrade ore from the Century mine, Australia. Sedimentary scour of underlying calcareous shale bed is indicated by arrows and synsedimentary slump and drag folds of beds (top of photograph). Selected chemical maps showing fine-lamina sphalerite and pyrite appear deposited as chemical sediment on the scour surface and crosscut by synsedimentary slumping. Note: Ba was below detection. C, Pyritic black shale contact with laminated barite "Gray Ore" from the Rammelsberg deposit, Germany, which averaged about 80 percent $\mathrm{BaSO}_{4}$ and 4 weight percent $\mathrm{Zn}+\mathrm{Pb}+\mathrm{Cu}$ combined (Large and Walcher, 1999). D, Banded ore from the Rammelsberg deposit consisting of rhythmic laminations of fine-grained pyrite, sphalerite, galena, and minor chalcopyrite. Note: Cu-rich clasts of "Kniest ore" from underlying footwall stringer zone deposited in the "Banded ore." Transported clasts contain crosscutting veinlet quartz, ankeritic calcite ( $\mathrm{Ca}, \mathrm{Fe}$ ), and calcite ( $\mathrm{Ca}$ ) with disseminations of chalcopyrite, pyrite, galena, and sphalerite. ( $\mathrm{BaSO}_{4^{\prime}}$ barite; $\mathrm{Ba}$, barium; $\mathrm{Ca}$, calcium; $\mathrm{Cu}$, copper; $\mathrm{Fe}$, iron; $\mathrm{Pb}$, lead; $\mathrm{Mn}$, manganese; Si, silicon; $\mathrm{Zn}$, zinc) 

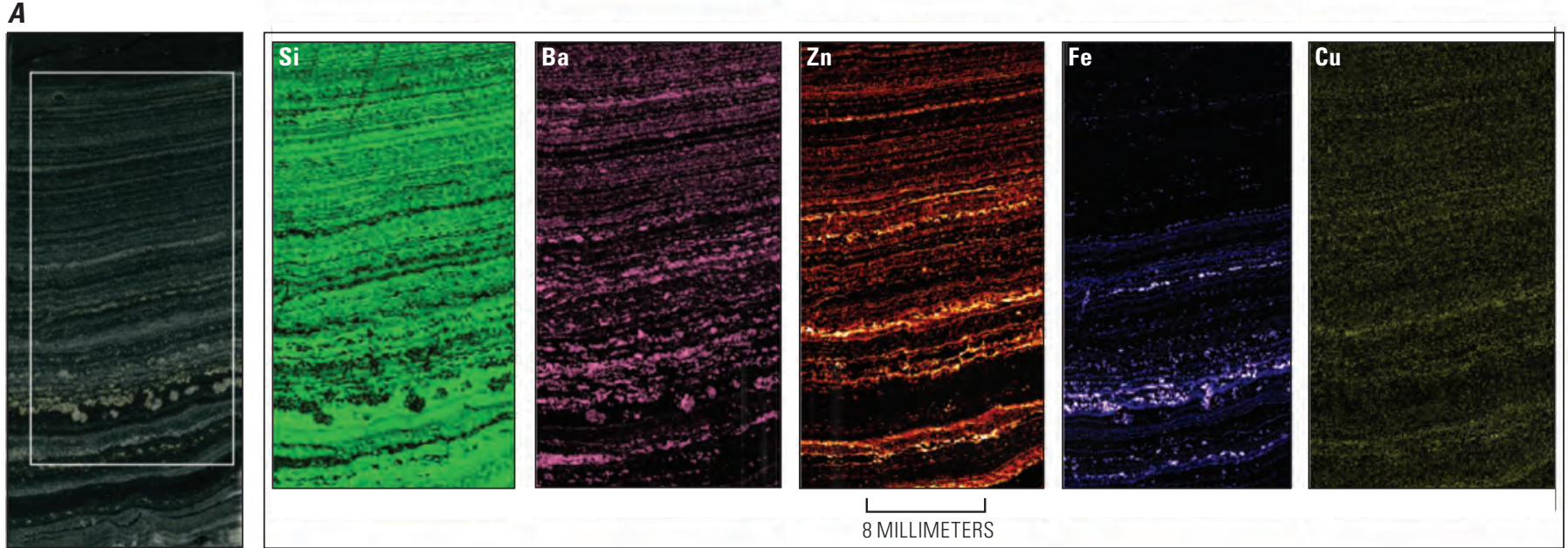

B
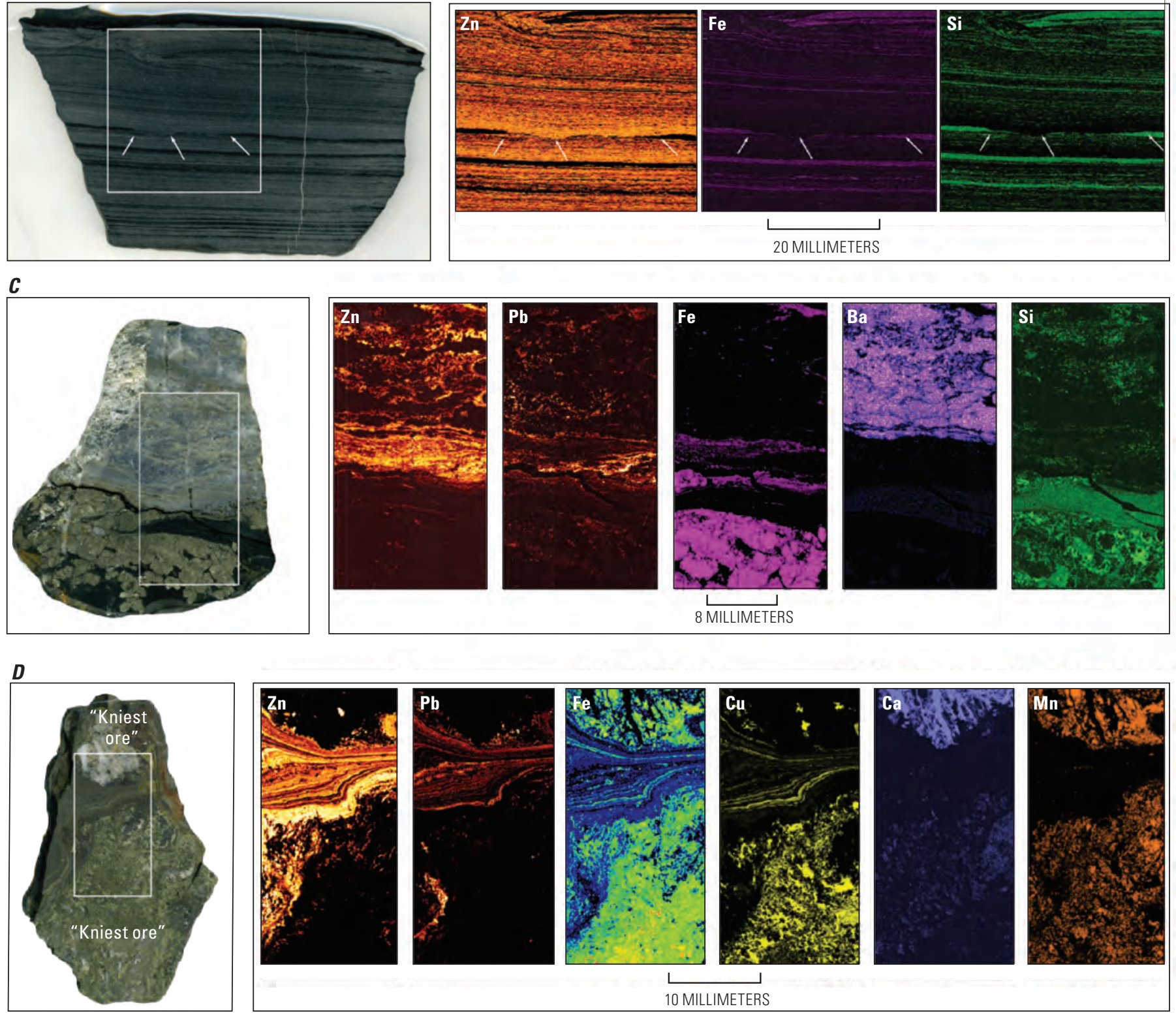
the principal sulfide mineral of most ores, except in the Red Dog, Howards Pass, and Century deposits, where sphalerite dominates (Leach and others, 2005b; Goodfellow and Lydon, 2007). The Fe sulfide in most ores is pyrite, except for the Sullivan and Mount Isa deposits (pyrrhotite) and the Duddar deposit in Pakistan (primarily marcasite). Primary economic minerals are sphalerite and galena and, although local concentrations of $\mathrm{Pb}$ can approach those of $\mathrm{Zn}$, sedex deposits are $\mathrm{Zn}$ dominant with $\mathrm{Zn}:(\mathrm{Zn}+\mathrm{Pb})$ ratios that average about 0.7 (Lydon, 1995). Minor chalcopyrite is typical of most ores and can be economically recovered in some deposits (for example, Rammelsberg). Sulfosalt minerals such as tetrahedrite, freibergite, and boulangerite occur in some deposits and can be a significant host of Ag (Lydon, 1995). Barite is present in about 25 percent of the Proterozoic and about 75 percent of the Phanerozoic sedex deposits (Goodfellow and others, 1993); in some cases, it makes up more than 25 percent of ores and is economically recovered. Carbonate minerals reported from sedex deposits include calcite, dolomite, and $\mathrm{Fe}$ - (siderite and ankerite) and Mn-carbonates. Phosphate accumulations are characteristic of many sedex deposits, but it is not yet known whether sedex-associated phosphate is introduced by the hydrothermal brine, as has been suggested for the Howards Pass deposit (Goodfellow and Jonasson, 1987), or is a remobilization from organic matter and ferric oxyhydroxides in basin sediments as the seas become anoxic (Emsbo and others, 2005). Enrichments of quartz in stratiform ores, as chert and siliceous shales, are common, but the relation of quartz veining in vents and in vent-complex and ore-forming systems is usually equivocal (Leach and others, 2005b).

\section{Paragenesis}

Textural and paragenetic relations of fine-grained sedex ores have led to considerable debate as to the timing of mineralization, with interpretations ranging from syngenetic to syndiagenetic replacement to syntectonic (see Leach and others, 2005b; Large and others, 2005). While it is clear that the subsea-floor replacement of sediments (carbonate, barite, pyrite) is an important process in some sedex deposits (for example, Anarraaq, Kelley and others, 2004b; McArthur River [HYC], Large and others, 1998), there is now growing consensus that mineralization predates compaction and lithification of host rocks. Features such as load-casts and sedimentary compaction features that affect finely laminated fine-grained sulfide layers, synsedimentary debris flows that contain mineralized clasts, synsedimentary slumps that terminate mineralized beds and ore horizons, and microtextural evidence for the reworking of ore on the sea floor all establish the deposition of ore metals during the syngenetic to early syndiagenetic stages of sedimentation (fig. 12).

\section{Zoning Patterns}

Zoning patterns surrounding sedex deposits are well established (fig. 10) (Lydon, 1995, 2004a). Feeder zones, where present, are characterized by veins and wallrock replacements consisting of $\mathrm{Fe}$ - and $\mathrm{Fe}$-magnesium $(\mathrm{Mg})$-Ca-carbonates, quartz, pyrite, and pyrrhotite, but are not typically a significant component of the ore. Feeder zones can contain significant chalcopyrite that, in some cases, can be economic; for example, at the Rammelsberg deposit these zones contained as much as 2 percent $\mathrm{Cu}$ (Large and Walcher, 1999). The vent complexes above feeder zones are characterized by massive, brecciated, and sometimes weakly bedded sulfide ore that commonly attains the highest ore grades of the deposits. The vent complex is also characterized by the lower sphalerite:galena ratios and the highest concentration of sulfosalts. Outboard of vent zones, well-bedded ores are characterized by finely laminated ore sulfides that are interbedded with host-rock sediments and contain varying amounts of chert, barite, and $\mathrm{Fe}-\mathrm{Mg}$-Ca-carbonates. Hydrothermal assemblages contain decreasing sulfides with distance from ore, and significant barite, chert, Fe-Mg-Cacarbonates, magnetite, and hematite can be traced for tens of kilometers from deposits.

\section{Textures, Structures, and Grain Size}

Sedex ores are typically fine-grained and layered and have banded textures. Grain sizes of all sulfide minerals in unmetamorphosed deposits are generally less than 30 micrometers $(\mu \mathrm{m})$. Grain size systematically increases with metamorphic grade. Deformed and folded deposits such as Mount Isa, Hilton, Lady Loretta, and Sullivan contained coarser sulfides in the range of $20-1,000 \mu \mathrm{m}$, whereas deposits metamorphosed at higher grades (that is, amphibolite) can have grain sizes with diameters of as much as $1 \mathrm{~cm}$ (Large and others, 2002).

\section{Relations Between Alteration, Gangue, and Ore}

\section{Mineralogy}

Alteration minerals that have been reported for hydrothermal feeder zones of sedex deposits include dolomite, alkali feldspar, clay, quartz, muscovite, chlorite, ankerite, siderite, tourmaline, and sulfides (Goodfellow and others, 1993; Lydon, 1996, 2004a; Davidson, 1998; Leach and others, 2005b). The sulfide minerals, though not typically concentrated at economic levels in feeder zones, include pyrite, pyrrhotite, galena, sphalerite, chalcopyrite, and arsenopyrite and sulfosalt minerals such as tetrahedrite, freibergite, and boulangerite. 

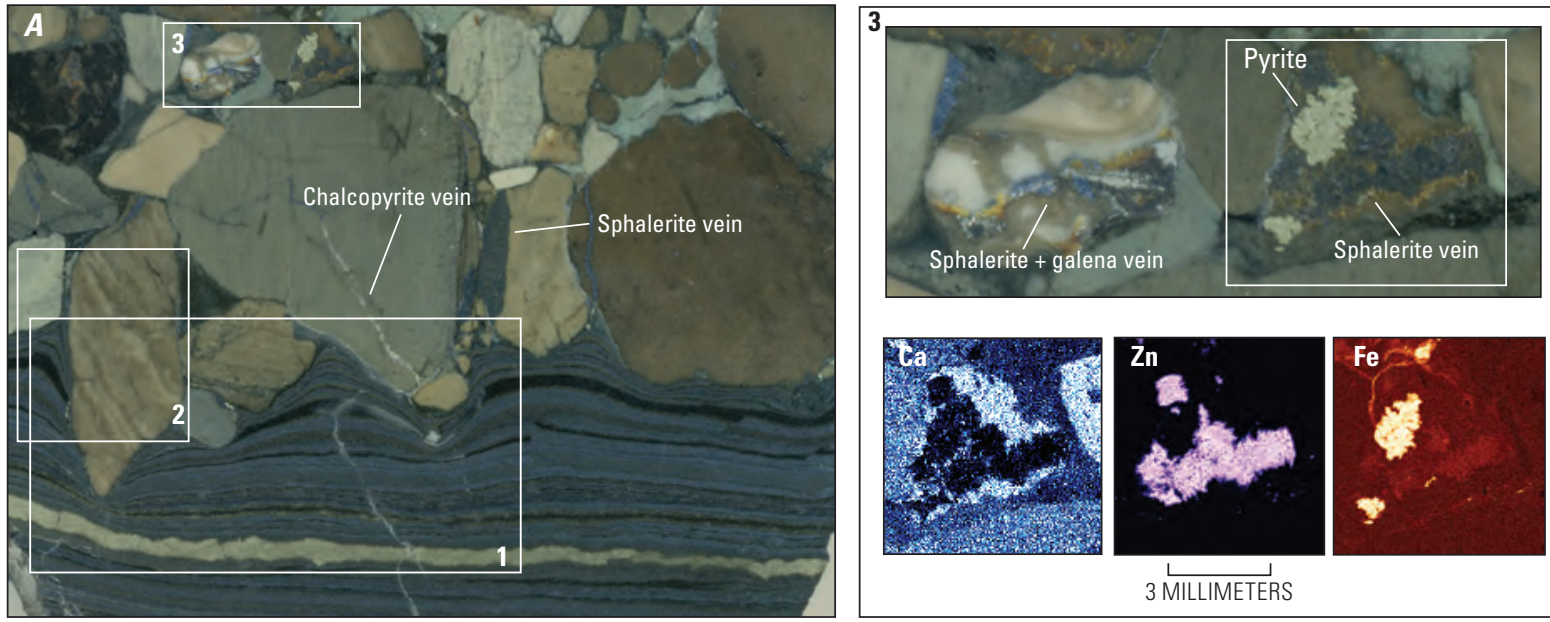

3 MILLIMETERS
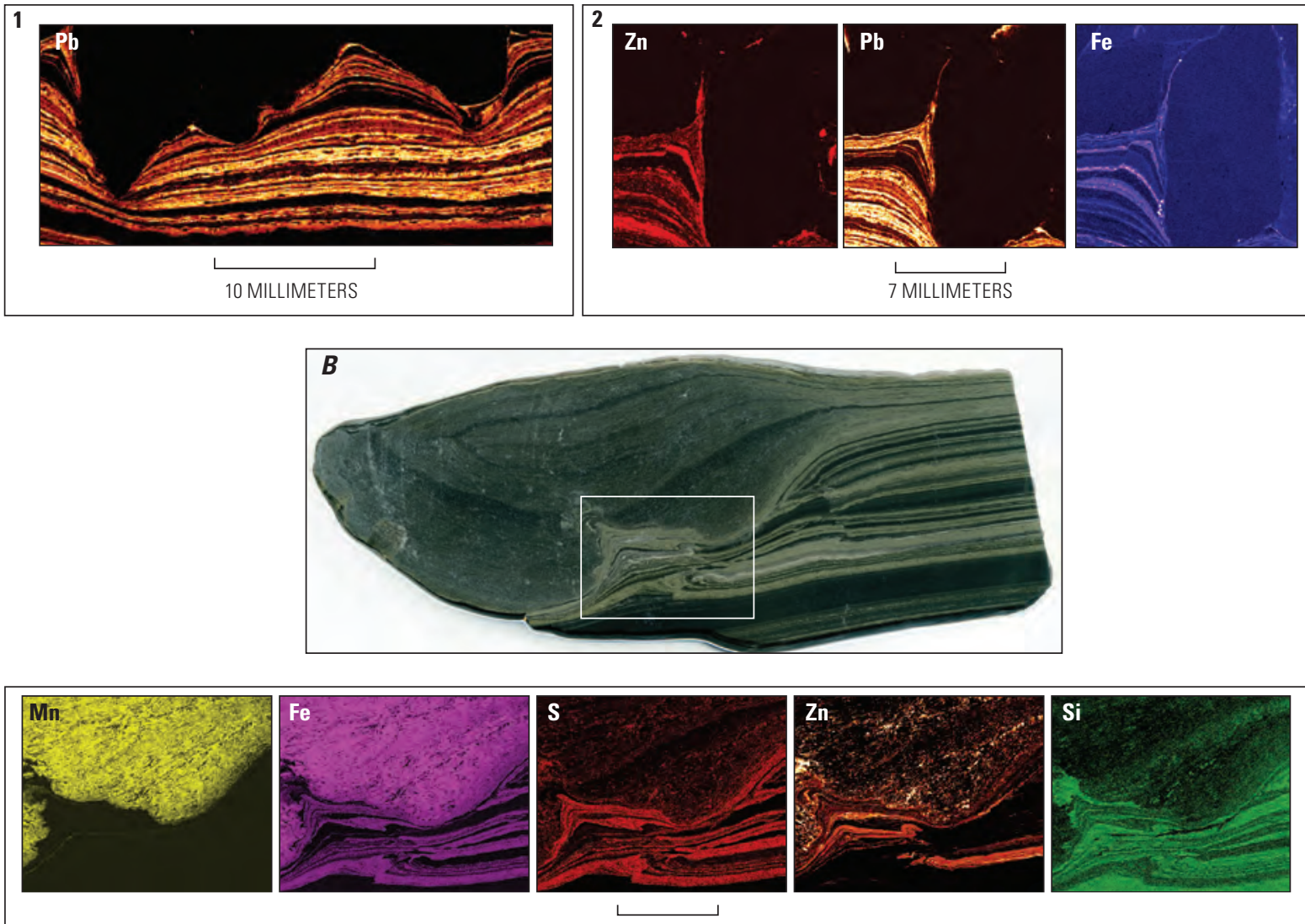

20 MILLIMETERS

Figure 12. Textural evidence showing modification of sedex ores through sea-floor processes, suggesting sedex ores predate compaction and lithification of their host rocks. $A$, Polymictic sedimentary conglomerate overlying rhythmically laminated highgrade sphalerite and galena ore from the I 3/4 horizon in the McArthur River (HYC) deposit, Australia. Inset 1 shows a scanning micro $\mathrm{x}$-ray fluorescence (XRF) map of $\mathrm{Pb}$ concentrations demonstrating load-casts and sedimentary compaction features that affect finely laminated fine-grained sulfide layers. Inset 2 shows maps of $\mathrm{Zn}, \mathrm{Pb}$, and Fe concentrations. Note the deformation and partial truncation of fine, chemically graded laminae at contact with the conglomeratic base of the overlying turbidite and intralaminae deformation. Inset 3 shows mineralized clasts containing footwall vein material in the synsedimentary debris flows. Photograph and chemical micro-XRF maps of clast show mineralization is limited by sharp contacts to the clast, suggesting reworking of ore on the sea floor in the debris flow. B, Precompaction diagenetic Mn-Fe carbonate nodule (Fe, Mn maps) from the Century deposit, Australia. The nodule, itself a hydrothermal product, overgrew laminated ore sediments prior to compaction of the laminated carbonaceous mudstone. Fine pyrite, sphalerite, and galena laminae were plastically deformed and injected into the embayment in the nodule during compaction and lithification. (Fe, iron; Mn, manganese; Pb, lead; S, sulfur; Si, silicon; Zn, zinc; Ca, calcium) 


\section{Zoning Patterns}

The hydrothermal alteration associated with sedex deposits is generally not well characterized. Investigations of footwall alteration are limited because mineralization in hydrothermal feeder zones is typically uneconomic and expressions of alteration can be subtle and appear much like those produced by burial diagenesis and greenschist metamorphism (Lydon, 1995, 2004a).

Widespread footwall alteration extending hundreds of meters below the ore horizon, and as far as several kilometers from the deposit along fault zones, has been recognized in some deposits (Lydon, 1995, 2004a; Goodfellow and Lydon, 2007). Intense footwall silicification, for example, has been reported at the Tom, Jason, Vangorda, Rammelsberg, and Red Dog deposits (Goodfellow and Rhodes, 1991; Large and Walcher, 1999; Lydon, 2004a; Slack and others, 2004). "Kniest ore" in the Rammelsberg deposit consists of a pipelike structure that is silicified and contains quartz veins that are characterized by local concentrations of chalcopyrite (Large and Walcher, 1999). Intense silicification in the Red Dog deposit has been interpreted to be ore related (Slack and others, 2004), yet paragenetic, isotopic, and fluid inclusion microthermometry and electrolyte analyses suggest that much of the silicification may be due to deep burial during the Mesozoic Brookian orogeny (Leach and others, 2004). The hydrothermal alteration pipe underlying the Sullivan deposit is much larger and conspicuous than pipes at other deposits (Lydon, $2004 \mathrm{a}, \mathrm{b}$ ). The alteration is unique because it is dominated by tourmalinite (consisting of greater than 30 volume [vol.] percent tourmaline), which occurs as a pipe-like structure about 1,000 $\mathrm{m}$ in diameter and extends for hundreds of meters below the main ore horizon. At least five "stages" represented by seven types of hydrothermal alteration have been documented in the Sullivan deposit, but only a chlorite-pyrrhotite alteration assemblage can be directly linked to the main ore-forming event (Lydon, 2004b). The conspicuous tourmalinite pipe is thought to have formed during mud volcano activity triggered by the intrusion of thick gabbroic sills into the wet and consolidated sediments below the ore horizon. Brecciation and alteration associated with these mud volcanoes are thought to have acted as permeable conduits that focused the later ore-forming brine event (Lydon, 2004b).

Regional- to basin-scale alteration that has been recognized in sedex deposit-hosting basins can, as discussed in later sections, be controlled by major far-field tectonic events that drive basin-scale fluid flow. Davidson (1998) documented regional alkali alteration in the McArthur basin, which he attributed to regional fluid flow associated with the formation of the McArthur River (HYC) deposit. Similarly, the occurrence of MVT deposits and hydrothermal dolomite in the platform margin in the Selwyn basin has been linked to a far-field consequence of sedex mineralization farther in the basin. As discussed later, these occurrences may be very significant for assessing deposits in sedimentary basins.

\section{Weathering/Supergene Processes}

A review of the supergene characteristics of sedex deposits by Kelley and others (1995) demonstrates that the weathering and oxidation of deposits results in Fe-rich gossan. Gossan profiles are best developed in deposits with high Fe content, low metal:sulfur ratios in sulfide minerals, and wall rock with low buffering capacity, as they tend to form low-pH water during weathering. Oxidation depth is controlled partly by fracture density near orebodies and the presence of pyrrhotite, which is highly reactive with oxygenated groundwater. Resulting oxidation may extend as much as $100 \mathrm{~m}$ below the surface and extend up to $300 \mathrm{~m}$ adjacent to major faults and shear zones (Kelley and others, 1995).

Primary minerals in gossans are goethite and hematite, and minor quartz, kaolinite, and beudantite, all of which are important in exploring for sedex deposits. For example, galena generally weathers to form anglesite and cerussite, but coronadite, mimetite, nadorite, pyromorphite, plumbogummite, and lanarkite have also been reported. Silver halide minerals have also been reported. Secondary zinc minerals include hemimorphite, smithsonite, hydrozincite, and wurtzite. Gossan's rich hemimorphite and smithsonite at the surface led to the discovery of the McArthur River (HYC) deposit (Large and others, 2005). Secondary sulfate minerals include jarosite, barite, and alunite. Native sulfur, produced by the oxidation of marcasite, is present at the Red Dog deposit, Alaska (Kelley and others, 1995). Secondary zinc minerals such as hemimorphite have also been discovered overlying the XY deposit (Howards Pass district, Yukon Territory).

Taylor and Scott (1982) demonstrated that chemical analyses and stepwise discrimination analysis of gossan geochemistry in the Mt. Isa basin using Pb, P, Ba, As, Zn, Mn, S, $\mathrm{Co}$, and $\mathrm{Sb}$ were able to distinguish barren and fertile gossans. The use of similar discrimination analysis has been widely applied in northern Australia for the last 30 years (Large and others, 2005).

\section{Geochemical Characteristics}

\section{Trace Elements and Element Associations}

In addition to ore-forming elements, sedex deposits contain a large suite of ore-associated elements that are not generally recovered from sedex deposits; these elements commonly include $\mathrm{Mn}, \mathrm{Mg}, \mathrm{Hg}$, As, Sb, Se, In, Ga, Bi, Co, Ni, and $\mathrm{Tl}$ (Goodfellow and Lydon, 2007). Because of the wide dispersion halos and zoning around orebodies, as described in later sections, many of these elements are used during exploration to detect and vector towards undiscovered ore. While Mn does not precipitate as a sulfide mineral under normal ore-formation conditions, gangue carbonate minerals in sedex ores commonly contain as much as 4 percent 
Mn, which in carbonate-rich ores can result in ores with greater than 1 percent Mn (Large and McGoldrick, 1998). Documented concentrations of many trace metals in sedex ores include tens of parts per million of $\mathrm{Hg}, \mathrm{Se}, \mathrm{In}, \mathrm{Tl}, \mathrm{Ni}$, and $\mathrm{Bi}$ and hundreds of parts per million of As and $\mathrm{Sb}$ (Large and McGoldrick, 1998; Large and Walcher, 1999; Lydon, 2004a; Slack and others, 2004; Goodfellow and Lydon, 2007). Vent-proximal ores that contain sulfosalt minerals such as tetrahedrite, freibergite, boulangerite, and arsenopyrite can contain thousands of parts per million of As and $\mathrm{Sb}$ (Lydon, 1995). While many of these elements can substitute in sphalerite, the bulk of these metals reside in pyrite. Kelley and others (2004b) found significant concentrations of As ( $<1.1$ weight [wt.] percent), Co $(<0.1$ wt. percent), $\mathrm{Cu}$ ( $<0.2$ wt. percent), $\mathrm{Ni}(<0.2$ wt. percent), $\mathrm{Tl}(<1.2$ wt. percent), and $\mathrm{Sb}(<0.7$ wt. percent) in pyrite. Similarly, pyrite from Howards Pass contains As ( $<0.06$ wt. percent), Ni ( $<0.2$ wt. percent), $\mathrm{Cu}(<0.2 \mathrm{wt}$. percent), molybdenum (Mo) (0.02 wt. percent), $\mathrm{Se}(0.01$ wt. percent), and $\mathrm{Sb}(<0.7$ wt. percent) (Goodfellow and Jonasson, 1987). Sphalerite from the Red Dog deposit contains concentrations of $\mathrm{Fe}(<7.3$ wt. percent), $\mathrm{Cd}(<1.0$ wt. percent), As ( $<0.2$ wt. percent), $\mathrm{Pb}(<1.0$ wt. percent), and $\mathrm{Hg}(<0.4$ wt. percent). Sphalerite samples from Broken Hill, Australia; Balmat, New York, United States; Faro, Canada; and Rammelsberg and Meggan, Germany, contained $\mathrm{Hg}$ concentrations between 0.3 and 4,680 ppm (Schwartz, 1997).

\section{Zoning Patterns}

Geochemical zoning patterns surrounding sedex deposits are well established (Lydon, 1996, 2004a) and generally reflect the mineralogic zoning described in the section "Zoning Patterns" (p. 22) (fig. 10). Feeder zones can typically contain the highest concentrations of $\mathrm{Cu}$. Systematic increases in $\mathrm{Zn}: \mathrm{Pb}$ and decreases in $\mathrm{Zn}: \mathrm{Ba}, \mathrm{Zn}: \mathrm{Fe}$, and $\mathrm{Zn}: \mathrm{Mn}$ outward from vent complexes are well documented in several deposits (see Lydon, 2004a). Generally, vent complexes are also characterized by high concentrations of Ag, As, $\mathrm{Sb}$, and $\mathrm{Tl}$, which reflect the proximal occurrence of sulfosalts. Distal trace element halos are characterized by black shales and cherts that can contain tens to thousands of parts per million of $\mathrm{Zn}, \mathrm{Pb}$, $\mathrm{Tl}, \mathrm{As}, \mathrm{Ba}, \mathrm{Hg}$, and $\mathrm{Mn}$ that are zoned for tens, even hundreds, of kilometers from orebodies.

\section{Fluid-Inclusion Thermometry and Geochemistry}

The fine-grained nature of sedex ores, the scarcity of well-preserved footwall stringer zones, and the structural and thermal disruption that has overprinted most ores all limit conventional fluid-inclusion microthermometry studies of sedex deposits. Although limited, a few successful fluid-inclusion studies have demonstrated that sedex deposits form at temperatures of $100-200{ }^{\circ} \mathrm{C}$ from brines with $10-30 \mathrm{wt}$. percent total dissolved solids (Gardner and Hutcheon, 1985; Bresser, 1992; Leach and others, 2004, 2005b; Lydon, 2004b; Polito and others, 2006).

\section{Stable Isotope Geochemistry}

Sulfide is essential to ore formation because ore metals are trapped by $\mathrm{H}_{2} \mathrm{~S}$ produced on or just below the sea floor. Because of its importance in ore formation, sulfide has been intensely studied, using sulfur isotopes to attempt to identify its source. Recent compilations of isotope data for sedex sulfide minerals by Leach and others (2005b) document a range for all deposits of -8 to $+30 \%$ and wide ranges for individual deposits of as much as 10 to $15 \%$. Interpretations of sulfur source have varied, but there is now general consensus that the ultimate source was marine sulfate that had been reduced to $\mathrm{H}_{2} \mathrm{~S}$ through bacterial sulfate reduction and, perhaps, thermochemical sulfate reduction (Large and others, 2002, 2005; Lydon, 2004a; Leach and others, 2005b; Goodfellow and Lydon, 2007). A relation between secular marine $\delta^{34} \mathrm{~S}$ trends and sedex deposits has been noted (Goodfellow, 1987; Goodfellow and Jonasson, 1987; Goodfellow and Lydon, 2007; Johnson and others, 2009). A recent $\delta^{34} \mathrm{~S}$ and $\delta^{18} \mathrm{O}$ study of barite from sedex $\mathrm{Zn}-\mathrm{Pb}-\mathrm{Ag}$ and Ba-only deposits has demonstrated linear or concave-upward trends on a $\delta^{34} \mathrm{~S}$ and $\delta^{18} \mathrm{O}$ cross-plot that project down toward the isotopic composition of seawater sulfate (Johnson and others, 2009). The trends resemble those observed in barite mineralization occurring at fluid seeps on modern continental margins and likely reflect a combination of (1) different rates of bacterial sulfate reduction with organic matter as the primary electron donor, as well as donations from methane or possibly light hydrocarbons; (2) oxygen isotope exchange between reduction intermediates; and (3) $\mathrm{H}_{2} \mathrm{O}$ and sulfate availability (Johnson and others, 2009). The evidence that bacteria metabolize organic compounds and thus produce sulfide that precipitates the ore metals in local sedimentary environments highlights the importance of organic matter in the genesis of sedex deposits.

\section{Radiogenic Isotope Geochemistry}

A significant amount of $\mathrm{Pb}$ isotope data has been collected for sedex ores (see Leach and others, 2005b). The majority of the data indicate a crustal source, which suggests that $\mathrm{Pb}$ was derived from the clastic sediments filling the basin (Ayuso and others, 2004; Large and others, 2005; Leach and others, 2005b). Similarly, $\mathrm{Sr}$ in barite and hydrothermal carbonates has been shown to be highly radiogenic (Goodfellow and others, 1993; Ayuso and others, 2004; Goodfellow, 2004), which is also consistent with a clastic sediment source. Strontium in distal barite has been shown to be less radiogenic, consistent with the mixing of exotic hydrothermal $\mathrm{Sr}$ and ambient seawater Sr (Goodfellow and Rhodes, 1991). 


\section{Petrology of Associated Igneous Rocks}

Not relevant to this model.

\section{Petrology of Associated Sedimentary Rocks}

\section{Importance of Sedimentary Rocks to Deposit Genesis}

Sedimentary host rocks are inextricably linked to the genesis of sedex deposits. For instance, organic matter in local host rocks is crucial to ore formation because, as described in the section "Nature of Traps and Wallrock Interaction that Trigger Ore Precipitation" (p. 34), ore metals are trapped by $\mathrm{H}_{2} \mathrm{~S}$ generated by bacterial sulfate reduction in the local sedimentary host rocks. Moreover, once ore deposition has occurred, organic matter enrichments help maintain the reducing conditions that enhanced the preservation of ore sulfides. Another important attribute of the fine-grained sedimentary environment that produces the carbonaceous, pyritic, finegrained sediments that host sedex ores is that it represents depositional environments with low rates of sedimentation and subdued detrital input, thus limiting the dilution of both organic matter and sedex metals and increasing the potential for economic metal accumulations.

Researchers have stressed the importance of oxidized rift-fill continental clastic rocks as source rocks for the metals in sedex deposits. The basin-filling rift accumulation that occurs several kilometers below ore horizons consists of coarse continental clastic sediments, including conglomerates, red beds, sandstones, and turbidities. These sedimentary rocks are important for ore formation because, as described in detail in later sections, they are permeable, voluminous, and rich in easily leached metals and, during water-rock interactions, they buffer ore fluids to oxidized compositions favorable for metal transport (see Emsbo and others, 1999; Cooke and others, 2000; Emsbo, 2000).

\section{Rock Names}

Host rocks of sedex deposits are fine-grained marine sedimentary rocks classified as carbonaceous shale and chert in the Howards Pass and Red Dog deposits, dolomitic shale or siltstone in the McArthur River (HYC), Mount Isa, George Fisher, and Hilton deposits, and micritic limestone in the Meggen deposit. Orebodies generally comprise stacked sulfide-rich ore layers parted by pyritic, organic-rich shales, siltstones, and, at some localities, debris flows. Turbidities and slump breccias are common within the ore-hosting sequences at a number of deposits, including Meggen, Rammelsberg, Jason, Tom, Faro, and McArthur River (HYC). Distal hydrothermal facies on the fringes of orebodies are typically organic- and sulfide-rich black shales, cherts, and siltstones that are commonly described as metalliferous black shales.

\section{Mineralogy, Textures, and Grain Size}

Unmetamorphosed host rocks of sedex deposits range from shales with fissility parallel to layering and bedding to mudstones that are similar in composition but do not show the fissility. Ore shales and mudstones are fine-grained clastic sedimentary rock composed of fine-grained $(1-50 \mu \mathrm{m})$ bedding-parallel layers (centimeter-scaled) of ore minerals (predominantly sphalerite, galena, pyrite, and barite) intermixed with mud-sized grains of parallel-orientated clay minerals and organic material with various proportions of silt-sized particles of other minerals including quartz and chert, calcite, dolomite, and siderite. Minor bentonite beds are present within the ore-hosting sequences at a number of deposits, including Meggen, Rammelsberg, Jason, Faro, and McArthur River (HYC). Turbidities and slump breccias interbedded with ore horizons can contain polymictic sedimentary conglomerates containing centimeter- to meter-scaled clasts of limestone, sandstones, chert, and mudstone; in some cases, clasts containing physically transported ore minerals are common in sedex deposits.

\section{Environment of Deposition}

$\mathrm{Sedex} \mathrm{Zn}-\mathrm{Pb}$-Ag deposits occur in fine-grained clastic rocks (shales and siltstones) outboard of shallow-water carbonate that eventually transgress and cover rift-fill depocenters during the sag phase of rift-generated sedimentary basins. Sedex deposits form in bathymetric lows that represent euxinic, low-energy depositional environments dominated by organic-rich, pyritic, fine-grained shale and mudstone. Bathymetric lows in the basin are generally believed to be structurally controlled third-order basins that provide favorable locations for dense, bottom-hugging, metalliferous brines to accumulate and react with locally derived $\mathrm{H}_{2} \mathrm{~S}$ to form sulfide ores in an anoxic environment. It is important that these depositional third-order basins are distal from eroding landmasses, as described in previous section, because rapid sedimentation results in the dilution of both organic matter and sedex metals, thus inhibiting economic accumulations of ore.

\section{Petrology of Associated Metamorphic Rocks}

Not relevant to this model. 


\section{Theory of Deposit Formation}

\section{Ore Deposit System Affiliation(s)}

Sedex deposits are a subtype of a larger group of sediment-hosted $\mathrm{Pb}-\mathrm{Zn}$ deposits that includes MVT, Irishtype, and BHT deposits. Despite the geologic differences highlighted in the section "Deposit Model-Clarification and Exclusions," these deposits are all hosted in sedimentary basins and are formed by parallel genetic processes. See Leach and others (2005b) for a detailed review of these interrelations.

\section{Source of Fluids Involved in Ore Component Transport}

The supposition that sedex deposits were formed by saline basinal brines derived from their host basin was a critical advance in formulating a theory for sedex deposit genesis (Hutchinson, 1980; Badham, 1981; Lydon, 1983). Although direct study of sedex ore fluids has been limited, a few robust fluid-inclusion studies have verified that sedex deposits form from 100 to $200{ }^{\circ} \mathrm{C}$ brines with salinities between 10 and 30 wt. percent total dissolved solids (Gardner and Hutcheon, 1985; Ansdell and others, 1989; Bresser, 1992; Leach and others, 2004; Polito and others, 2006). Despite the importance to the understanding of sedex deposit genesis, the sources within basins of dissolved salt and water in the ore-forming brines is poorly understood. Historically, direct dissolution of evaporites in the flow path of meteoric/marine waters has been called on as the source for dissolved salts (Goodfellow and others, 1993; Lydon, 1995). Although evaporites commonly form early in rift-basin evolution, a shortcoming of the saltfrom-evaporite hypothesis, as highlighted by Lydon (2004b), is that evaporites have not been reported in the rift sequences of any sedimentary basins hosting sedex deposits. Other proposed sources of salt are connate fluids trapped in sediments during burial (Lydon, 1995; Garven and others, 2001; Yang and others, 2004, 2006; Large and others, 2005) and the gravitational influx of brines generated by seawater evaporation on platforms at the same time that sedex host rocks are being deposited (Davidson, 1998; Leach and others, 2004; Lydon, 2004b). Estimates suggest that thousands of cubic kilometers of brine are required to form large sedex deposits or districts (Goodfellow and others, 1993; Garven and others, 2001; Cathles and Adams, 2005). Irrespective of brine source, basinscale processes are required to produce a volume of brine this large. Thus, determining whether potential brine sources occur within a basin may allow for an effective assessment of its potential for hosting sedex deposits.

Geochemical studies and stable and radiogenic isotopic studies of modern basin brines have identified two processes for generating saline brines in sedimentary basins, both ultimately related to subaerial evaporation of seawater (see Hanor, 1994).
Major solutes in basinal brines are derived from either (1) residual brine that infiltrated down into underlying sedimentary sequences during evaporation or (2) dissolution of evaporite minerals, primarily halite, in the subsurface. A third proposed mechanism, membrane filtration, has not been demonstrated in natural environments and is untenable for large-scale production of highly saline brines (Hanor, 1994). Solute ratios help discriminate between the two possible brine sources in modern basinal brines (Rittenhouse, 1967; Carpenter, 1978). Both end-members and mixtures of them are recognized in modern sedimentary basins, but the primary source of salt in most basins, even those filled with salt, is residual brine (Carpenter, 1978; Kharaka and others, 1987; Walter and others, 1990; Moldovanyi and Walter, 1992; Hanor, 1994, 1996).

Fluid inclusion solute data from six sedex deposits (Century, McArthur River [HYC], Sullivan, Red Dog, Watson's Load, and Silver King) demonstrate that ores contain residual brine from seawater evaporation (Emsbo, 2009a, b). The chlorine:bromine $(\mathrm{Cl}: \mathrm{Br})$ and sodium:bromine $(\mathrm{Na}: \mathrm{Br})$ mole ratios for all six deposits plot on or near the seawater evaporation line. The data imply that the primary salinity source for the fluids that formed the sedex deposits was evaporatively concentrated seawater. Moreover, the data plot in the center of the relatively small compositional field for Mississippi Valley-type (MVT) basinal brines, which suggests that these deposits share a common origin. It is significant that nearly all of the $\mathrm{Cl}: \mathrm{Br}$ values are below the modern seawater value of 670 and extend down to 220 , which indicates that the brines formed from seawater near halite saturation. The similarity between sedex and MVT fluid compositions supports previous hypotheses that the two ore types formed from fluids of similar origins. Because neither deposit type provides evidence for halite dissolution as a primary source for the parent fluid, residual brines are considered fundamental to the genesis of all basin-hosted $\mathrm{Zn}-\mathrm{Pb}-\mathrm{Ag}$ deposits.

It has been demonstrated that evaporation of large volumes of seawater to salt saturation requires specific conditions: (1) shallow platform environments with circulation highly restricted by barriers such as sills or reefs, allowing evaporation to exceed the influx of fresh seawater, and (2) paleolatitude positions of $25^{\circ} \pm 10^{\circ}$ characterized by hot, arid climates in which evaporation exceeds precipitation (Warren, 2006). A striking feature of sedex basins is that they are rimmed by unusually large $\left(10^{5}\right.$ and $10^{6}$ square kilometers $\left.\left[\mathrm{km}^{2}\right]\right)$ shallow-water epeiric carbonate platforms that represent ideal sedimentary environments for brine generation. Evidence for evaporative environments in marginal basin sag-phase sequences has been noted in several basins (Davidson, 1998; Leach and others, 2004; Lydon, 2004b; Goodfellow and Lydon, 2007), and paleolatitude reconstructions indicate that sedex basins were in positions conducive to evaporation during their sag phase (Goodfellow and others, 1993; Leach and others, 2005a). Among the six major sedex basins considered in this analysis (fig. 1), all have evaporative platform sequences with 
evaporite minerals (anhydrite and some halite), breccias formed by salt dissolution or escape, or regional dolomitization. Dolomitization, both primary and secondary replacement, is a robust indicator of high-salinity evaporative environments (Moore, 1989). Moreover, as described in the section "Density-Driven Fluid Flow-A New Fluid-Flow Model” (p. 32), evaporation correlates in time with ore formation.

\section{Deduced Geologic Assessment Criteria}

- The study of sedex basins combined with new fluidinclusion data shows that sedex deposits formed from residual brines generated by seawater evaporation. Because of the extensive platform areas needed to produce the large volumes of brine required to form sedex deposits, evaporative sediments should be recorded in the platform stratigraphy at or below prospective stratigraphic intervals. Indicators include evaporite minerals (anhydrite, some halite), breccias indicating salt dissolution or escape, and regional dolomitization of the platform. These indicators are observable in all six sedex deposit-hosting basins evaluated here.

- Paleolatitude reconstruction is an efficient method for determining if a basin is likely to have experienced seawater evaporation during its history, and such reconstruction may provide an effective method for screening prospective basins for sedex deposits.

- The absence of salt dissolution signatures in fluid that formed sedex deposits, combined with a lack of evaporites in the rift sequences of sedex deposit-hosting basins, suggests that evaporites in the fluid-flow path are not essential to the formation of sedex deposits.

\section{Sources of Ligands and Chemical Transport and Transfer Processes Involved in Ore Component Transport}

During the past 30 years, sedex deposit research, in conjunction with geochemical studies of modern brines and geochemical modeling, has provided insights into the source, transport, and deposition of metals in sedimentary basins. The studies constrain the temperature, salinity, $\mathrm{pH}$, and chemical conditions necessary to transport $\mathrm{Pb}, \mathrm{Zn}$, and $\mathrm{Ag}$ in basin brines. Fluid inclusion data, mineral assemblages, and isotopic data indicate the deposits formed at $100-200{ }^{\circ} \mathrm{C}$ from fluids with neutral to moderately acidic $\mathrm{pH}$ and salinities from 10 to 30 wt. percent total dissolved solids (TDS). Additional insights on the brines can be obtained from comparisons with modernday brines, from fluid inclusion data for MVT deposits, and from thermodynamic modeling.

There is a general consensus that ore metals are transported dominantly as chloride complexes, and therefore salinity (chlorinity) is a primary control on their solubilities. Empirical and thermodynamic evidence suggests that saline brine (greater than about 15 percent TDS) is necessary to form a sedex deposit. A compilation of chemical analyses of modern metal-rich brines (Hanor, 1996) shows that chlorinity of about $10^{5}$ milligrams per liter $(\mathrm{mg} / \mathrm{L})(17 \mathrm{wt}$. percent TDS) is a threshold below which $\mathrm{Zn}$ concentrations are less than 1 ppm, which is far below what is necessary to form a sedex deposit (Hanor, 1996).

Similarly, fluid temperatures obtained from fluid inclusions in minerals in sedex deposits are greater than $100^{\circ} \mathrm{C}$, and chemical modeling of metal solubility indicates that $100{ }^{\circ} \mathrm{C}$ is the minimum temperature for moving ore-forming quantities of $\mathrm{Pb}$ and $\mathrm{Zn}$ (Cooke and others, 2000; Emsbo, 2000). On the basis of this constraint, Southgate and others (2006) have proposed the concept of a "thermal leaching window," a temperature interval of burial of approximately $150-250{ }^{\circ} \mathrm{C}$, at normal geothermal gradients, through which a stratigraphic package of metal source rock can be efficiently leached, liberating metals to a deep basin brine. Temperature gradients of 20-25 degrees Celsius per kilometer $\left({ }^{\circ} \mathrm{C} / \mathrm{km}\right)$ are common in sedimentary basins, and $30^{\circ} \mathrm{C} / \mathrm{km}$ is commonly assumed as the upper limit in models of various processes in sedimentary basins (Raffensperger and Vlassopoulos, 1999; Lin and others, 2000; Armstrong, 2005). Theoretically, surface heat flow in continental regions is typically 50 to 65 megawatts per square meter $\left(\mathrm{MW} / \mathrm{m}^{2}\right)$ (Turcotte and Schubert, 1982). Because of lower-than-average heat production in sedimentary rocks, basal heat flows in sedimentary basins should span a similar range, except in active rift basins where basal heat flow may reach $90 \mathrm{MW} / \mathrm{m}^{2}$. Sedimentary rocks typically have thermal conductivities of 1.5 to 2.5 watts per meter degree Celsius $\left(\mathrm{W} / \mathrm{m} \bullet{ }^{\circ} \mathrm{C}\right)$ (Clauser and Huenges, 1995). If we assume a basal heat flow of $60 \mathrm{MW} / \mathrm{m}^{2}$, no internal heat production, and a thermal conductivity of $2 \mathrm{~W} / \mathrm{m} \cdot{ }^{\circ} \mathrm{C}$, then a temperature gradient of $30^{\circ} \mathrm{C} / \mathrm{km}$ during the sag phase of a sedimentary basin is possible. With a typical mean annual surface temperature of $15^{\circ} \mathrm{C}$, this thermal gradient will result in a temperature of $105^{\circ} \mathrm{C}$ at a depth of $3 \mathrm{~km}$. Thus, $3 \mathrm{~km}$ is a conservative estimate for the total sediment thickness required to form a sedex deposit. This conclusion is supported by the fact that ores in the six most important sedex basins (fig. 1) occur in stratigraphic intervals overlying at least $5 \mathrm{~km}$ of sediment fill somewhere in the basin.

Analyses of modern brines and chemical modeling have demonstrated that, although variables like temperature and $\mathrm{pH}$ are important, high $\mathrm{Zn}$ and $\mathrm{Pb}$ solubilities in brines above $100{ }^{\circ} \mathrm{C}$ result primarily from a combination of high salinity and low $\mathrm{H}_{2} \mathrm{~S}$ concentration (Kharaka and others, 1987; Moldovanyi and Walter, 1992; Hanor, 1996). Chemical analyses of modern brines and thermodynamically calculated solubilities of base metals show an inverse relation to $\mathrm{H}_{2} \mathrm{~S}$ contents, and $\mathrm{Zn}$ and $\mathrm{Pb}$ concentrations in brines decrease by several orders of magnitude in the presence of even moderate contents of $\mathrm{H}_{2} \mathrm{~S}$ (Kharaka and others, 1987; Moldovanyi and Walter, 1992; Hanor, 1996; Cooke and others, 2000; Emsbo, 2000). Conversely, $\mathrm{H}_{2} \mathrm{~S}$ in sedimentary brines dramatically increases the solubility of $\mathrm{Au}$ (Emsbo, 2000). The solubility 
of $\mathrm{Ba}$ is also controlled by salinity, temperature, and $\mathrm{pH}$, but its dominant control in basin brines is the concentration of $\mathrm{SO}_{4}$, as Ba solubilities are extremely low in the presence of $\mathrm{SO}_{4}$. Variations in the proportions of base metals, barite, and Au were used by Emsbo (2000) to classify sedex deposits into very large $\mathrm{Pb}-\mathrm{Zn}$ - $\mathrm{Ag}$ deposits, intermediate-size $\mathrm{Pb}-\mathrm{Zn}$ $\mathrm{Ag}-\mathrm{Ba} \pm \mathrm{Au}$ deposits, and barite deposits with low base metals with or without Au. This spectrum is believed to reflect the concentration and redox state of sulfur in the brine, which is ultimately controlled by the lithology and redox buffering capacity of basin-fill sediments. For example, the large $\mathrm{Zn}-\mathrm{Pb}$ sedex deposits in the McArthur basin of Australia commonly contain greater than $100 \mathrm{Mt}$ of ore and almost no barite and have Au contents that are the same as or less than those of surrounding unmineralized rocks. These characteristics indicate that they formed from oxidized brines that contained very little, if any, reduced sulfur (Large and others, 1998; Cooke and others, 2000). Conversely, intermediate $\mathrm{Zn}-\mathrm{Pb}-\mathrm{Ag}-\mathrm{Ba} \pm \mathrm{Au}$ sedex deposits are generally barite-rich and are typically significantly smaller $(<50 \mathrm{Mt})$. These characteristics indicate that they formed from fluids that contained enough $\mathrm{H}_{2} \mathrm{~S}$ to transport some $\mathrm{Au}$, yet at levels still low enough to form base metal deposits (Emsbo, 2000). Finally, high Ba-Au sedex deposits in Nevada and in the Neoproterozoic Nanhua rift basin of southeast China suggest that they were deposited from $\mathrm{H}_{2} \mathrm{~S}$-rich and $\mathrm{SO}_{4}$-poor fluids at the other end of the spectrum of sedex deposits and that the high $\mathrm{H}_{2} \mathrm{~S}$ content of the fluids suppressed the solubility of base metals, precluding formation of large, more characteristic $\mathrm{Zn}-\mathrm{Pb}-\mathrm{Ag}$ sedex deposits (Emsbo and others, 1999, 2005; Emsbo, 2000).

Because it is a dominant control on metal solubility, $\mathrm{H}_{2} \mathrm{~S}$ concentration is an important parameter in basinal processes. Deep in sedimentary basins, $\mathrm{H}_{2} \mathrm{~S}$ is generated by thermochemical sulfate reduction as well as by thermal decomposition of kerogen, coal, and high-sulfur oils (Hunt, 1996). It is significant that these processes all involve organic carbon, consistent with the observation that the amount of $\mathrm{H}_{2} \mathrm{~S}$ in deep drill holes correlates with the content of organic matter in surrounding rocks (Le Tran, 1972). In addition to the generation of $\mathrm{H}_{2} \mathrm{~S}$, a fundamental control on $\mathrm{H}_{2} \mathrm{~S}$ concentration in sedimentary brines is its removal by reaction with Fe to form pyrite. The highest $\mathrm{H}_{2} \mathrm{~S}$ concentrations observed in sedimentary basins are in lithologies that are low in reactive Fe, such as carbonates (Hunt, 1996). Therefore, the amount of $\mathrm{H}_{2} \mathrm{~S}$ at deeper levels in sedimentary basins is controlled by the balance between the rate of production through thermochemical sulfate reduction and the rate of removal through the sulfidation of reactive Fe. Many researchers have stressed the importance of oxidized rift-fill continental clastic rocks (for example, red beds) as a source of metals in sedex deposits (see Cooke and others, 2000; Emsbo, 2000). Most sedex basin rift-fill sequences are dominated by fluvialdeltaic and shallow marine continental clastic sequences composed of red beds, sandstones, conglomerates, and siltstones. These sequences, which are low in organic carbon and high in reactive $\mathrm{Fe}$, are ideal for buffering saline brines to compositions favorable for the transport of $\mathrm{Zn}, \mathrm{Pb}$, and $\mathrm{Ag}$.

\section{Deduced Geologic Assessment Criteria}

- Empirical and thermodynamic evidence suggests that saline brine (more than about 17 percent TDS) is necessary to form a sedex deposit. Thus, geologic evidence of brine-generating environments is required for a basin to be permissive for sedex mineralization.

- Fluid temperatures of at least $100{ }^{\circ} \mathrm{C}$ are required to form sedex deposits. According to thermal regimes of sedimentary basins, at least $3 \mathrm{~km}$ of sediment fill above a crystalline basement is required for these temperatures and for a basin to be a prospective $\mathrm{Zn}-\mathrm{Pb}-\mathrm{Ag}$ deposit. Moreover, basins of variable fill depths can only be a prospective $\mathrm{Zn}-\mathrm{Pb}-\mathrm{Ag}$ deposit in stratigraphic horizons overlying more than $3 \mathrm{~km}$ of sediment.

- Oxidized syn-rift sediments will tend to buffer ore fluids to compositions necessary for metal extraction and transport because of their low organic and high reactive Fe contents.

- Variations in the proportions of base metals, barite, and Au in mineral occurrences may ultimately reflect the lithology and redox-buffering capacity of basin-fill sediments in the metal source regions and thus provide information about metal endowment and prospectivity of sedimentary basins.

\section{Sources of Metals and Other Ore Components}

The radiogenic and stable isotopic compositions of sedex ores constrain the sources of ore components. Many studies have demonstrated that $\mathrm{Pb}$ and $\mathrm{Sr}$ are dervived from the continental clastic sediments contained in host basins (Ayuso and others, 2004; Emsbo and Johnson, 2004; Large and others, 2005; Leach and others, 2005b). Moreover, fluid-flow and chemical arguments (see earlier sections) support the hypothesis that oxidized, coarse clastic sediments (such as red beds, conglomerates, and sandstones) in underlying rift-fill sequences are the most likely source of ore metals.

The vast mass of metal that has been deposited in and surrounding major sedex deposits requires volumes of source rock that are large enough to be recognizable on a basin scale. For example, the largest sedex deposits can contain greater than $20 \mathrm{Mt}$ of $\mathrm{Zn}$ metal. Tonnage estimates do not include lower grade, uneconomic mineralization marginal to deposits, which is likely to contain a metal mass 10 times greater than the ore reserve (Cathles and Adams, 2005). For example, lowering the cutoff grade ( 7 percent $\mathrm{Zn}+\mathrm{Pb}$ ) for the Tom deposit in Canada by 1 percent increases the ore tonnage estimate fivefold (Goodfellow and others, 1993). Thus, a conservative estimate of the $\mathrm{Zn}$ deposited by a world-class sedex system would be greater than $200 \mathrm{Mt}$. A study by Zielinski and others 
(1983) of continental red beds, such as those proposed as source rock for sedex deposits, showed an average $\mathrm{Zn}$ content of approximately $70 \mathrm{ppm}$. Leaching tests on red beds suggest that 22 percent of the $\mathrm{Zn}$ (approx. $15 \mathrm{ppm}$ ) is extractable under conditions expected for a metal transporting solution (Zielinski and others, 1983). To furnish the metal for a worldclass sedex deposit, more than 6,000 cubic kilometers $\left(\mathrm{km}^{3}\right)$ of continental red beds at a typical sandstone bulk density of 2.2 grams per cubic centimeter $\left(\mathrm{g} / \mathrm{cm}^{3}\right)$ are required, if we assume 100 percent efficient leaching of extractable $\mathrm{Zn}$, transport, and precipitation of $\mathrm{Zn}$ at the site of ore formation.

By total mass, sulfur is the most enriched element in sedex deposits. Isotopic studies have demonstrated that sulfur originates from marine sulfate, which is reduced to sulfide by bacterial or thermogenic processes. It is unlikely that lacustrine water, which is typically two orders of magnitude lower in sulfate, could supply sufficient sulfate to sequester the metal in a major sedex deposit. Whereas it been proposed that some sedex deposits formed in lacustrine environments (see Goodfellow and others, 1993), this interpretation is inconsistent with marine sulfur isotope signatures and paleontological and sedimentological evidence. The marine sulfate requirement may also have temporal significance. For example, the absence of Archean sedex deposits may be a consequence of a low-sulfate ocean inferred for Archean time (Leach and others, 2005a; Lyons and others, 2006; Goodfellow and Lydon, 2007). It has also been suggested that a correspondence between sedex deposits and global anoxic events may reflect periods when reducing conditions favored sulfide generation and efficient precipitation and preservation of metal sulfides (Turner, 1992).

\section{Deduced Geologic Assessment Criteria}

- Mass balance considerations suggest that thousands of cubic kilometers of rift-fill coarse clastic sediments are required to supply the amount of metal contained in a major sedex deposit. This observation suggests that a prospective basin should have a volume of rift-fill sequences recognizable on the basin scale. Moreover, the volume of available source rock within a basin may place a limit on the maximum amount of metal that can be extracted and fixed in sedex deposits.

- Seawater is required to supply sulfur for a sedex deposit. Evidence of marine conditions should be evident in the stratigraphic intervals that host sedex deposits.

- The requirement of marine sulfate as a source of sulfur may limit sedex deposit formation to Proterozoic and Phanerozoic time. The correspondence of sedex deposits with regional, and perhaps global, anoxic events may identify periods of time that are favorable for formation of sedex deposits.

\section{Fluid Drive-Thermal, Pressure, and Geodynamic Mechanisms}

There is little agreement as to the nature of the hydrologic processes - such as sources of energy, heat transport and transfer processes, and geodynamic processes - that drove the hydrothermal systems responsible for sedex deposits. Previously proposed models can be classified into three general types, which are briefly summarized and evaluated in this section: sedimentary compaction models, free convection models, and topographically driven flow models. Also, because of the identified difficulties of previous models and the potential importance of a new model to assessments for sedex deposits, a new fluid-flow model is proposed is proposed in the following section (fig. 13) that incorporates new fluid inclusion data, results of basin analysis, and constraints from previous fluidflow models.

\section{Sedimentary Compaction Models}

Several previous models for the formation of sedex deposits proposed that fluids were driven and discharged to the sea floor by sediment accumulation and compaction (Lydon, 1983, 1986; Sawkins, 1984). The basin architecture highlighted by the stratal aquifer model of Lydon $(1983,1986)$ forms the conceptual underpinning for several sedimentary compaction fluid-flow models as well as for thermal convection models. Fundamental to the sedimentary compaction model are 2- to 3-km-thick successions composed of lowpermeability, fine-grained, sag-phase sediments that overlie permeable, syn-rift clastic rocks. The low-permeability cover is believed to act as an aquitard, attenuating flow and promoting the development of an over-pressured brine reservoir in underlying permeable clastic reservoirs. Breaching of the cover sequence by extensional faulting is thought to initiate fluid discharge, which continues as the sediment column compacts with declining fluid pressure. This model accords with the general architecture of sedex deposit-hosting basins, the occurrence of deposits in sag-phase sediments, and the localization of deposits along extensional faults that were active during mineralization. However, hydrologic modeling suggests that sedimentation and compaction rates in sedimentary basins are inadequate to mobilize sufficient quantities of fluid to form sedex deposits (Bethke, 1985; Neuzil, 1995). The "squeeze" model of Garven and others (2001), which proposed both compaction- and pressure-driven fluid flow in a transpressional regime, demonstrated that, although possible, a sedimentary compaction mechanism is still unlikely to provide the drive required to form sedex deposits.

Multiple periods of sedex mineralization throughout the same depocenter, a characteristic of most sedex basins, is also difficult to explain with this model. Compaction-driven models would require basinwide equilibration of fluid pressures and full compaction of the sedimentary column to produce the volume and flow of brine needed to form a substantial ore deposit. Thus, the breaching of an over-pressured reservoir and the subsequent 


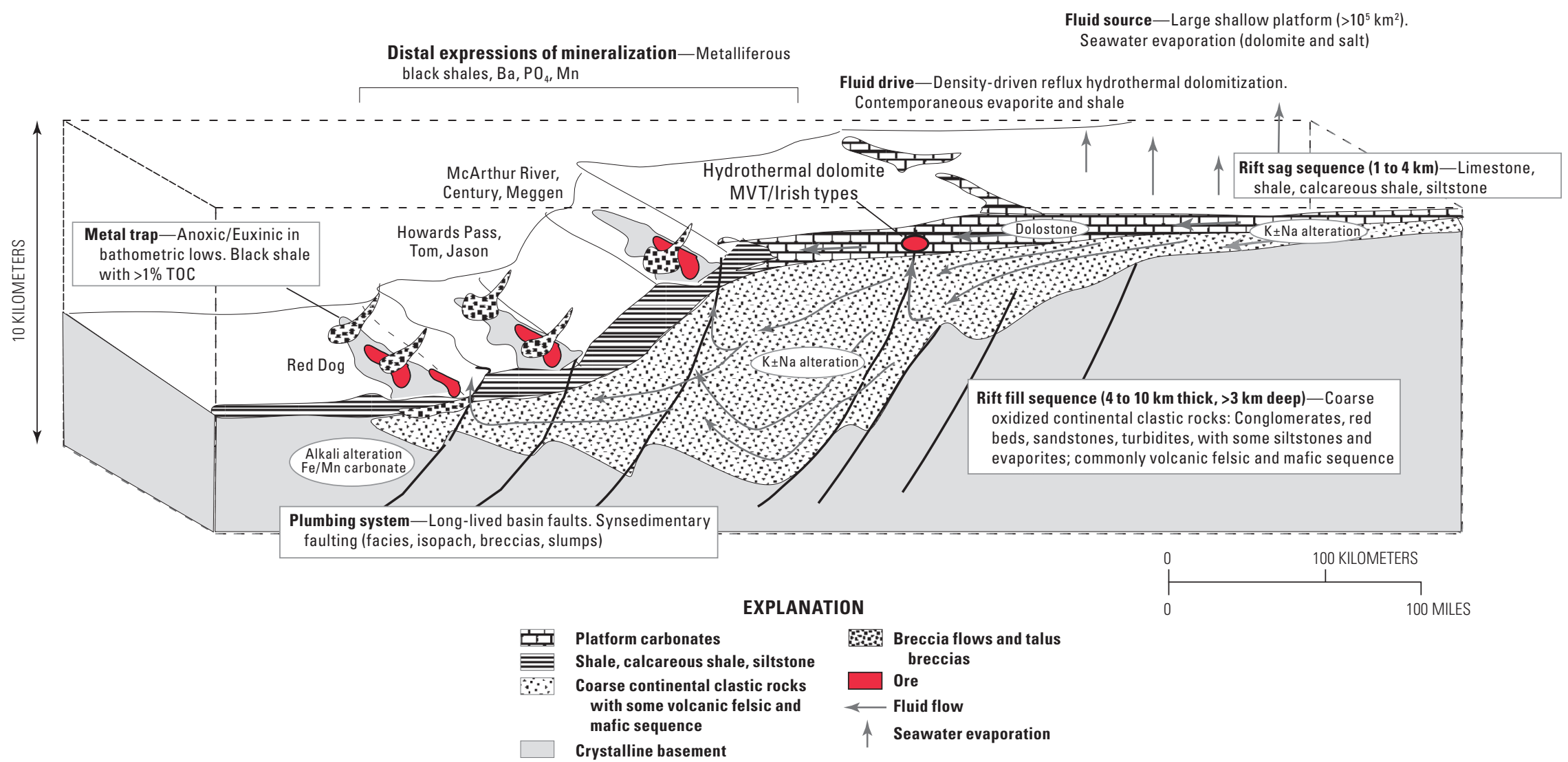

Figure 13. Geologic setting of sedex zinc-lead-silver deposits with deduced geologic assessment criteria as put forth in this report. Gray arrows represent fluid-flow paths inferred from the distribution of altered rocks and an ongoing U.S. Geological Survey numerical fluid-flow modeling project. The locations of several important sedex deposits relative to the shallow-water platform margin are indicated and may reflect the structural architecture of the basin or the maturity of the rift cycle. (MVT, Mississippi Valley type; TOC, total organic carbon; Ba, barium; Mn, manganese; km, kilometer; km², square kilometer; $\mathrm{PO}_{4}$, phosphate; $\mathrm{K}$, potassium; $\mathrm{Na}$, sodium; $\mathrm{Fe}$, iron) 
compaction and squeezing of the sedimentary column because of irreversible loss of porosity and permeability should be a one-time event within a basin.

\section{Free Convection Models}

Convective fluid flow is favored by many researchers to account for the formation of sedex deposits (Russell and others, 1981; Goodfellow and others, 1993; Garven and others, 2001; Large and others, 2005). Garven and others (2001) developed numerical models to compare previously proposed fluid-flow models, including sediment compaction, free convection, and topographically driven flow, on a geologically well constrained finite element mesh through the southern McArthur basin. They concluded that the most likely mechanism for the formation of the McArthur River (HYC) deposit was free convection driven by density variations that resulted from normal geothermal gradients. They proposed a two-stage hydrologic model similar to the stratal aquifer model of Lydon $(1983,1986)$. In stage one, brines formed by halite dissolution or evaporation infuse underlying clastic sediments during the rift phase of basin development. Burial of the rift-phase clastic sediments by lowpermeability sag-phase sediments is thought to have promoted the formation of an isolated brine reservoir, in which convection cells developed and persisted, because of tectonic stability, for about 70 million years (m.y.). Long-lived convective circulation is thought to be crucial because it promotes scavenging of metals from the reservoir rocks and development of metal-rich brines. During the second stage of the model, rupture of the overlying aquitard by large, parallel, high-angle normal faults establishes a recharge-discharge convective cell that allows the hot, metal-rich reservoir brines to ascend a fault while being replaced by cold seawater descending along a sympathetic fault. Garven and others (2001) calculated that fluid zinc contents of $1,000 \mathrm{ppm}$ would be sufficient to transport the $20 \mathrm{Mt}$ of zinc contained in the McArthur River (HYC) deposit in less than 7 m.y. The duration of 7 m.y., though plausible, is considered an upper bound for the duration of sedex hydrothermal systems. A more conservative estimate of $100 \mathrm{ppm} \mathrm{Zn}$ in solution would give an untenable 70 m.y. to form a world-class sedex deposit. Moreover, Yang and others (2004) coupled transient fluid flow, heat, and solute transport modeling on the same finite element mesh used by Garven and others (2001), and they thus demonstrated that the model results are very sensitive to specific fault and aquifer geometries and basin salinity structure. For example, the salinity structure observed in most modern basins, with the highest salinities in the bottom of the basin, would require unrealistic thermal gradients to maintain convection. Application of a convective fluid-flow model to the Red Dog deposit requires paleo-heat flows of $150-160 \mathrm{MW} / \mathrm{m}^{2}$ to drive hydrothermal convection (Garven and others, 2003). This heat flow is at least three times as high as the heat flow measurements in the sag phase of modern basins and is about twice those in riftphase basins (see above). No geologic evidence has been found to support paleo-heat flows of this magnitude in sedex basins.
Salt mass balance, without recharge of new brine into the system, is another potential problem with convective models, particularly in basins with several mineralizing events. For example, the simulations by Yang and others (2004) show a depletion of reservoir salinity to about 10 percent TDS after about 60,000 years. A drop in salinity to 10 percent would limit $\mathrm{Zn}$ solubility to less than $1 \mathrm{ppm}$ (see previous section). Similarly, assuming a fluid $\mathrm{Zn}$ concentration of 1,000 ppm and about 10 percent porosity, mass balance considerations suggest that $200 \mathrm{~km}^{3}$ of brine would be required to form a large sedex deposit containing the $20 \mathrm{Mt}$ of $\mathrm{Zn}$ that corresponds to the entire model reservoir volume. Using more conservative $\mathrm{Zn}$ concentrations of 10-100 ppm gives minimum brine volumes 10-100 times larger. The extraction of such a large mass of salt could potentially deplete the salinity of an entire basin. For example, an ore fluid with $100 \mathrm{ppm} \mathrm{Zn}$ would require the extraction of $2,000 \mathrm{~km}^{3}$ of brine. Its replacement by seawater (3.5 percent salt) would dilute a $\pm 60,000-\mathrm{km}^{3}$ reservoir, with 10 percent porosity, below the 17 percent salinity threshold required to transport $\mathrm{Zn}$, making it difficult to form multiple deposits sequentially in the basin. Overall, mass balance considerations suggest that multiple large sedex events in the same basin, characteristic of important sedex basins (fig. 1), would require brine replenishment, a phenomenon that is unaccounted for in current convection flow models.

\section{Topographically Driven Flow Models}

Topographically driven flow models, similar to those proposed for MVT and Irish-type deposits, have been proposed for sedex deposits. However, there is little evidence of the regional-scale orogenic belts that would have provided the high elevations required to drive regional fluid flow at the time of sedex ore formation (Goodfellow and others, 1993; Large and others, 2005). Garven and others (2001) determined that elevated basin margins established during rifting are unlikely to drive sufficient fluid flow. Moreover, sedex deposits form during thermal subsidence when basins are rimmed by large, low-relief carbonate platforms that extend for hundreds of kilometers from the basin margin.

\section{Density-Driven Fluid Flow- A New Fluid-Flow Model}

As noted previously in this report, new fluid inclusion solute data suggest that sedex deposits are formed from residual brine that results from the evaporation of seawater. The general correspondence between the timing of mineralization and intense evaporation on platform margins, as well as the position of the important sedex basins at paleolatitudes that would have favored evaporative brine formation, is noteworthy.

The large shallow-water epeiric carbonate platform sequences $\left(>10^{5} \mathrm{~km}^{2}\right)$ rimming sedex basins have been deposited at latitudes $\left(25^{\circ} \pm 10^{\circ}\right)$ conducive to high evaporation rates. Paleolatitude reconstructions of Phanerozoic sedex 
deposit-hosting basins have shown that the majority of ores were deposited at such paleolatitudes and high-resolution stratigraphic, biostratigraphic, and geochronologic analysis of the six most fertile sedex basins reveals that the 12 mineralizing episodes described previously correspond closely to discrete periods of intense evaporation of seawater on the platform (Emsbo, 2002, 2009a, b; Leach and others, 2005a). The temporal correspondence between mineralization and evaporite deposition suggests a causative relation.

Numerical modeling by Jones and others (2002) has demonstrated that dense residual brines generated by seawater evaporation will infiltrate basin carbonate platform margins to depths of greater than $6 \mathrm{~km}$, migrate, and eventually vent into adjacent ocean basins. Although not specifically applied to sedex deposits, this model demonstrates that density-driven fluid flow, or brine reflux, can drive high-salinity brine flow through carbonate platforms at substantial rates, on the order of 100 cubic meters per year per meter of section. Numerical modeling of fluid flow in basins with architectures more representative of those that host sedex deposits suggests that dense residual brines infiltrate and descend into deep, permeable clastic rock reservoirs (P. Emsbo, U.S. Geological Survey, unpub. data, 2010). Brines flow laterally through such clastic rock sequences toward the basin depocenter until expelled to the sea-floor by fault conduits in the distal basin. Calculated flow rates for density-driven simulations exceed those of other sedex fluid-flow models when similar permeability values are assumed. An important aspect of this modeling is the influence the permeability of rift-fill clastic sequences has on fluid flow. Slight reductions in the permeability of these sequences markedly decrease fluid flow to levels prohibitive to ore formation. Moreover, as demonstrated by the modeling of Jones and others (2002) of reflux brines in carbonate platforms, permeable faults along the platform margin will cause some fluid to migrate upward into shallow sequences of the platform margin. This flow might explain the common small MVT-style deposits or higher temperature saddle dolomite that have been recognized in most carbonate platforms inboard and approximately coeval with the basin facies that host the sedex deposits.

The fluid inclusion solute data, the temporal correlation between ore formation and seawater evaporation, and the numerical modeling jointly suggest that density-driven fluid flow triggered by the evaporation of seawater is fundamental to sedex ore formation. The association between sedex deposits and sag-phase sediments may have less to do with the influence of an aquitard on basin fluid flow than with the development of a basin environment during the sag phase characterized by large shallow-water epeiric carbonate platforms capable of generating large volumes of brine. It is interesting to note that the Belt basin is unusual in that a large evaporative platform margin developed during the rift phase. Thus, a density-driven model may explain the anomalous occurrence of the Sullivan deposit in rift-phase strata of the basin.

\section{Deduced Geologic Assessment Criteria}

- The empirical and conceptual relation of large evaporative shallow-water epeiric carbonate platforms to sedex deposits suggests that such a sedimentary environment is fundamental to sedex formation.

- The temporal correlation between ore formation and seawater evaporation suggests that distal stratigraphic intervals that are coeval with platform intervals exhibiting evidence of evaporative conditions (for example, evaporite minerals such as anhydrite and some halite, breccias indicating salt dissolution or escape, and regional dolomitization) should be viewed as highly prospective for sedex mineralization.

- The density-driven fluid-flow model suggests that the paleolatitude of sedimentary basins may be a useful parameter in identifying specific time intervals within basins that are prospective for sedex deposits.

- Fluid-flow modeling indicates that the permeability structure of rift-fill clastic sequences is critical to brine movement and sedex deposit formation.

- The occurrence of MVT-style mineralization and higher temperature dolomite along platform margins may be a strong indicator of the fluid-flow systems that form sedex deposits.

\section{Conduits or Pathways that Focus Ore-Forming Fluids}

It is well established that sedex deposits are associated with long-lived regional structures that control the development of first- and second-order basins (Large, 1980; Lydon, 1995; Kelley and others, 2004a; Large and others, 2005; Leach and others, 2005b; Goodfellow and Lydon, 2007). Deposits and districts are typically oriented along second-order structures that control basin half-graben depositional centers. The longevity of these structures, which is apparent from their influence on basin configuration and sedimentary facies through time, is thought to reflect repeated reactivations of deep-rooted primary basement faults (Large and others, 2002; Emsbo and others, 2006). Most deposits show a direct relation between active fault movement and ore formation. Fault movement is expressed as growth faults with rapid facies changes, periodic influx of coarse breccias and debris flows derived from fault-scarps, synsedimentary slumping, stratigraphic thickening toward subsiding basin margins, and foundering of basin environments. Interpreted rift-related structural regimes include normal extensional faults, orthogonal transform faults, and wrench faults with transpressional and transtensional segments (Emsbo and others, 1999; Large and others, 2002; Goodfellow and Lydon, 2007). Finally, the association of sedex deposits with post-ore thrust faults in tectonically disrupted strata reflects inversion of the basin by reverse movement on original normal faults (for example, Emsbo and others, 2006). 
Pathways of fluid flow are indicated by Fe- and Mncarbonate alteration and, in some cases, extensive silicification and perhaps tourmalinization (such as at the Rammelsberg, Sullivan, Tom and Jason, McArthur River [HYC], and perhaps Red Dog deposits) (Large and others, 1998; Kelley and others, 2004a; Lydon, 2004b; Goodfellow and Lydon, 2007). Early diagenetic dolostone formation associated with descending or advecting brines derived from overlying evaporite sequences is universal in sedex basins. Moreover, porous clastic sediments in platform sequences and rift-fill sediments in the deeper sequences in the McArthur basin have been shown to be regionally alkali metasomatized (Davidson, 1998).

An important consideration in sedex ore genesis is the physical behavior of fluids at the seawater/sediment interface. Sangster (2002) separated sedex deposits into ventproximal and vent-distal types on the basis of the presence or absence of discordant, feeder, vent, or stringer zones below the stratiform ore. In the case of vent-proximal deposits and those with sub-sea-floor replacement mineralization, such as the Anarraaq deposit in Alaska (Kelley and others, 2004a), the thickest accumulation of ore tends to be on the margin of feeder fault systems. In the case of the vent-distal deposits, metal accumulations are controlled by basin-floor topography. Exhaled brines, because of their density, hug the bottom and seek paleobathymetric lows in which they accumulate as brine pools. While bottom-hugging brines have been demonstrated to travel great distances in modern basins (Sangster, 2002), it is believed that most sedex deposits in fault-controlled, restricted, third-order basins lie within a few kilometers of major fault systems. Third-order subbasins are generally recognized by their greater proportion of reduced facies (pyriticand organic-rich sediments), increased intrastratal thicknesses, and increased presence of debris flows compared to stratigraphic equivalents elsewhere in the second-order basin.

\section{Deduced Geologic Assessment Criteria}

- Areas within a few to tens of kilometers of large basinbounding faults that control second-order basins within sedimentary basins are highly favorable.

- Indicators of synsedimentary faulting, such as abrupt and truncated facies boundaries in platform-to-slope transition, thick debris flows, intraformational breccias, changes in isopach thicknesses, and synsedimentary slump structures, are highly useful indicators of favorable stratigraphic horizons for ore.

- On a local scale, increasing intrastratal and debris flow thicknesses and increasing organic matter and pyrite concentrations in reduced sediments can be used as vectors toward basin lows where brine may have accumulated and formed ore.
- Extensive dolomitization of platform carbonate rocks and alkali-altered platform and rift-phase clastic sediments are strong indicators of productive sedex basins.

- On a local scale, faults that served as fluid conduits may be identified by wallrock alteration with $\mathrm{Fe}$ and Mn-rich carbonate rocks or silicification, and perhaps tourmalinization.

\section{Nature of Traps and Wallrock Interaction that Trigger Ore Precipitation}

A unique attribute of sedex deposits is that ore metals are trapped by $\mathrm{H}_{2} \mathrm{~S}$ generated by bacteria in local sedimentary environments. Organic carbon $\left(\mathrm{C}_{\text {org }}\right)$ in sedex deposits commonly ranges from 3 to 10 wt. percent (Turner, 1992; Goodfellow and others, 1993; Leach and others, 2005b) and is more abundant than in typical shales, which average about 0.2 wt. percent (Brumsack, 2006). Organic matter is important in the genesis of sedex deposits because bacterial sulfate reduction, in which bacteria metabolize organic compounds, produces the sulfide that precipitates the ore metals. In addition, $\mathrm{C}_{\text {org }}$ enrichments are a consequence of the enhanced preservation of components destroyed by oxidation, which characterizes anoxic depositional basins, and of increased accumulation rates of $\mathrm{C}_{\text {org }}$ relative to diluting terrigenous clastic sediments. An increase in organic productivity may reflect the flux of biolimiting nutrients and metals delivered to the ocean by hydrothermal fluids (Emsbo and others, 1999; Emsbo, 2004, 2008).

Berner and Raiswell (1983) and Leventhal (1983) noted a linear correspondence between the amounts of $\mathrm{C}_{\text {org }}$ and pyrite sulfur $\left(\mathrm{S}_{\text {metal }}\right)$ in normal marine sediments. Deviations from the linear relation are common and result from variations in the suitability of available $\mathrm{C}_{\text {org }}$ for metabolism by sulfate-reducing organisms, the availability of sulfate, and the abundance of reactive metals to capture produced sulfide. Modern euxinic environments are notable for their higher $\mathrm{S}: \mathrm{C}_{\text {org }}$ ratios relative to typical marine sediments (Berner and Raiswell, 1983; Leventhal, 1983). The S:C ratios (Goodfellow and others, 1993) and the sulfur isotope systematics of sedex deposits are consistent with euxinic environments in which bacterial sulfate reduction was rapid relative to the supply of sulfate (Lyons and others, 2006; Johnson and others, 2009). These chemical and isotopic characteristics are expected in environments containing abundant organic carbon. Analyses of both normal and euxinic marine sediments demonstrate that greater than $1 \mathrm{wt}$. percent $\mathrm{C}_{\text {org }}$ is required to account for the high sulfur content of sedex deposits. The data of Berner and Raiswell (1983) and Leventhal (1983) show that sediment with less than $1 \mathrm{wt}$. percent $\mathrm{C}_{\text {org }}$ typically contains less than 0.5 wt. percent $S_{\text {metal }}$ and thus limits the maximum amount of zinc that could be precipitated to less than $1 \mathrm{wt}$. percent, which 
is considerably below what is economic for sedex deposits. Therefore, $\mathrm{C}_{\text {org }}$ contents greater than $1 \mathrm{wt}$. percent are considered an indicator of a favorable host rock.

Accumulations of greater than $1 \mathrm{wt}$. percent $\mathrm{C}_{\text {org }}$ in marine sediments can be explained by sustained bottom-water anoxia or unusually high rates of organic-matter production (Rollkotter, 2006). Basins with stratified water columns, such as those with hypersaline bottom water, are particularly suited to the development of basal anoxic to euxinic water. A requirement for the development of euxinic water is that the flux of $\mathrm{C}_{\text {org }}$ must be sufficient to deplete the supply of electron acceptors that are preferentially favored over sulfate $\left(\mathrm{O}_{2}, \mathrm{NO}_{3}, \mathrm{MnO}_{2}\right.$, and $\left.\mathrm{Fe}_{2} \mathrm{O}_{3}\right)$. Depending on the physiography of the sea floor proximal to a forming sedex deposit, deposition and preservation of $\mathrm{C}_{\text {org }}$ are likely to extend laterally from the deposit as carbonaceous sediments typified by black shales. This lateral accumulation is especially likely given the association of sedex deposits with global anoxic events (Goodfellow and others, 1993).

Achieving high concentrations of $\mathrm{C}_{\text {org }}$ also has implications for the sedimentological characteristics of the depositional environment. Anoxia enhances $\mathrm{C}_{\text {org }}$ preservation, but the flux of diluting the clastic and chemical components of the sediment must also be limited to achieve high $\mathrm{C}_{\text {org }}$ contents. Rapid sedimentation would result in the dilution of both $\mathrm{C}_{\text {org }}$ and sedex metals such that economic accumulations would be unlikely. Therefore, sedex deposits with economic ore grades are more likely to appear in depositional third-order basins that are distal from eroding landmasses.

\section{Deduced Geologic Assessment Criteria}

- High contents of $\mathrm{C}_{\text {org }}$ are essential for the production of sulfide, which is necessary for precipitation of sedex ore metals; organic matter is therefore a useful guide in the evaluation of the suitability of a potential host rock.

- Regional or global anoxic events may be favorable time periods for mineralization.

\section{Structure and Composition of Residual Fluid Outflow Zones}

Sedex deposits are unique in that their ore fluids are vented into hydrologically restricted basins. Dispersion halos and zoning of $\mathrm{Fe}, \mathrm{Ba}, \mathrm{Si}$, and the ore metals are observed at distances of tens of kilometers from deposits (Goodfellow and others, 1993; Lydon, 1995; Large and others, 1996b; Large and McGoldrick, 1998; Large and others, 2005; Goodfellow and Lydon, 2007). Moreover, the presence of basinwide organic-rich metalliferous black shales and $\mathrm{PO}_{4}, \mathrm{Fe}$, and Mn deposits in mineralized horizons has been widely noted (Turner, 1992; Large and others, 1998; Emsbo, 2004; Emsbo and others, 2005; Goodfellow and Lydon, 2007).
The interrelations between diverse deposit types are poorly understood. Traditionally, the basinwide phenomena have been explained by upwelling of cold, nutrient-rich ocean waters onto the continental shelf. The increased nutrients in shallow marine environments are thought to cause a surge in bioproductivity and corresponding eutrophication, anoxic or dysoxic conditions, and sequestration of $\mathrm{C}_{\mathrm{org}}$, as observed along modern upwelling coastlines. In this model, metal and phosphate in the shale are derived from seawater and accumulated through a variety of biogenic and chemical mechanisms. Alternatively, Emsbo and others (2005) proposed that hydrothermal basinal fluids may have been the source of nutrients. Brines contain very high concentrations of biolimiting nutrients such as ammonium, reduced $\mathrm{C}$, trace metals, $\mathrm{Ba}$, and Si. Recent estimates have shown that the flux of nutrients from a large sedex hydrothermal system can exceed the modern riverine flux into the ocean (Emsbo and others, 2005; Emsbo, 2008). Such an immense nutrient flux into a single sedimentary basin would undoubtedly cause massive increases in primary productivity. The resulting eutrophication would establish anoxic conditions and preserve organic matter. Variations in the redox state of the discharged brine can explain the extraordinary metal enrichments and some of the compositional variation in the black shales (Emsbo and others, 2005; Emsbo, 2008). However, the low solubility of phosphate in hydrothermal fluids suggests that it was not introduced by the brines (Hofstra and others, 2004; Emsbo and others, 2005). A plausible phosphate source other than seawater might be the remobilization of phosphate adsorbed on detrital ferric oxyhydroxides as the seas become anoxic. An appealing aspect of this phosphate source is that it explains the temporal and spatial coincidence of phosphate and sedex deposits. Overall, the enormous flux of biolimiting nutrients and metals delivered to the ocean by hydrothermal fluids may have been sufficient to form the metal deposits and trigger basinwide anoxia and associated biological and chemical changes in the sedimentary basin.

\section{Deduced Geologic Assessment Criteria}

- Basinwide organic-rich metalliferous black shales and $\mathrm{PO}_{4}, \mathrm{Fe}$, and $\mathrm{Mn}$ deposits may identity prospective sedimentary intervals in basins.

- Zoning of metals and metal ratios can be used as local vectors toward areas with mineralization (fig. 10). Within a favorable horizon, increasing organic matter and pyrite and trace element concentrations (and ratios) in reduced sediments can be used as vectors toward areas favorable for ore. As described in this section, systematic zoning of elements like $\mathrm{Zn}, \mathrm{Pb}$, $\mathrm{Ba}, \mathrm{As}, \mathrm{Hg}$, and $\mathrm{Tl}$ has been documented for tens to hundreds of kilometers around deposits. Moreover, increasing ratios of ore metals like $\mathrm{Pb}: \mathrm{Zn}$ and $\mathrm{Ba}: \mathrm{Zn}$ have been demonstrated to be effective vectors towards ore for up to $10 \mathrm{~km}$ around deposits. 


\section{Exploration/Resource Assessment Guides}

\section{Geological}

The ore genesis model and the geologic assessment criteria deduced from empirical data and the current understanding of the physicochemical, geologic, and mass balance constraints on sedex ore formation are summarized in figure 13. In the following sections, it is demonstrated how these geologic criteria can be used in mineral assessments to define permissive tracts, assess the relative prospectivity of permissive tracts, and map favorability within permissive tracts. In each section, the criteria are ranked according to their relative importance.

\section{Attributes Required for Inclusion in Permissive Tract at Various Scales}

\section{Geologic Criteria that Define Permissive Tracts}

Central to the existing U.S. Geological Survey mineral assessment protocol is the determination of permissive tracts. Boundaries of permissive tracts are defined as areas outside of which the probability of a deposit occurring is negligible. This model has identified geologic criteria that can be used as a proxy for geologic processes essential for sedex formation. It is also important that the geologic criteria used be able to define permissive tracts at the scale of a regional assessment $(1: 500,000)$. In order for an area to be considered permissive, it must have the following attributes:

- Intracratonic or epicratonic sedimentary basin: All sedex deposits occur in intracratonic or epicratonic sedimentary basins. Thus, an intracratonic or epicratonic sedimentary basin is a prerequisite for this deposit type.

- Depth to crystalline basement greater than $3 \mathrm{~km}$ : It has been well established that fluid temperatures in excess of $100^{\circ} \mathrm{C}$ are required to form a sedex deposit. Empirical observations and the current understanding of the thermal regimes of sedimentary basins indicate that at least $3 \mathrm{~km}$ of sediment fill is required to achieve these temperatures.

- Organic-rich black shale or siltstone with greater than 1 percent $\mathrm{C}_{\text {org }}$ : A shale unit with greater than 1 percent $\mathrm{C}_{\text {org }}$ is essential for sedex ore formation and must be identified for an area to be permissive.

- Brine salinity source: Saline brine ( $>17$ percent TDS) is necessary to form a sedex deposit. Basin-scale processes are required to produce the volume of brine necessary to form a deposit. Thus, direct geologic evidence for saline brine generation, such as evaporite minerals, breccias indicating salt dissolution or escape, or regional dolomitized platform sequences, is required. In the rare case where platform margins are obscured or missing because of erosion or tectonic disruption, paleoreconstructions can be used to determine if a basin was at a latitude permissive of seawater evaporation during its history.

\section{Geologic Criteria Used to Evaluate the Prospectivity of Permissive Tracts}

Many of the geologic criteria defined in this section, though not adequate to limit permissive tracts, directly implicate basin and hydrothermal processes that may influence estimates of number, size, and density of undiscovered deposits within permissive tracts, defined here as tract prospectivity. Such criteria are listed below in order of decreasing importance:

- Already discovered sedex deposits or occurrences: All known sedex basins contain multiple deposits in multiple horizons. Thus, the occurrence of sedex ore mineralization is the strongest indicator of a prospective basin.

- Coeval evaporative platform and organic-rich basinal sediments: This analysis reveals that mineralizing episodes correspond to discrete periods of intense seawater evaporation on the platform and the formation of regional shales anomalously enriched in organic matter. The implication is that these phenomena are related to sedex ore formation and that their coincident occurrence is a strong indicator of sedex ore formation.

- Large evaporative shallow-water marine epeiric carbonate platform margins: The empirical and genetic relations documented here suggest that carbonate platforms are the source of ore brines and provide the fluid drive to form sedex deposits. The occurrence of multiple episodes of mineralization in the six most fertile sedex basins suggests that, once the proper basin architecture is established, sedex deposits will form when the basin is exposed to the proper climatic and paleolatitude conditions for brine generation.

- Oxidized rift-phase sediments: Empirical observation, radiogenic isotope studies, and chemical or fluid-flow modeling show that 2- to 4-km-thick sequences of syn-rift coarse continental clastic sediments (conglomerates, red beds, sandstones, turbidites, and subordinate volcanic successions) provided the metals for sedex deposits. Oxidized (low $\mathrm{C}_{\text {org }}$ and high reactive $\mathrm{Fe}$ ), permeable sequences at depths greater than $3 \mathrm{~km}$ are ideal. Mass balance estimates of leachable metal 
suggest that the volume of these rocks within a given basin may provide an upper limit to the total amount of metal available for ore formation.

- Evidence of hydrothermal activity: The large volume of fluids required to form sedex deposits leaves alteration footprints that can be recognized on the basin scale. This evidence can include extensive dolomitization of platform carbonate rocks and pervasive alkalialteration of clastic sediment aquifers. On the local scale, strong mineralogical and chemical alteration along growth faults and alteration and metal halos can be used to vector toward the deposits.

- Distal signatures of mineralization: Regional shales anomalous in $\mathrm{C}_{\text {org }}$, metals, and sedimentary $\mathrm{Ba}, \mathrm{Mn}, \mathrm{Fe}$, and $\mathrm{PO}_{4}$ deposits are strong indicators of sedex deposits.

- Chemical composition of already discovered mineralization: Varying proportions of base metals, barite, and $\mathrm{Au}$ of sedex ores may ultimately reflect the lithology and redox buffering capacity of basin-fill sediments in the metal source regions, which may be a highly useful indicator for deposit formation, metal endowment, and prospectivity of a sedimentary basin.

- Age of the basin: The requirement of marine sulfate as a source of reduced sulfur may limit sedex deposit formation to Proterozoic and Phanerozoic time. The two most productive time periods of sedex formation, the Proterozoic (approx. 1.8-1.4 Ga) and the Paleozoic (550-300 Ma), may identify favorable times for sedex formation. Certainly, the correspondence of known sedex deposits to regional, and perhaps global, anoxic events may identify periods of time that are favorable for additional discoveries.

\section{Knowledge that Enables Favorability Zonation of Permissive Tracts}

- Basin architecture: On a regional scale, areas within tens of kilometers of large, long-lived basin-bounding faults that controlled second-order basin features are highly favorable. The close association of synsedimentary faults (recognized by features in the regional to local stratigraphy or basin architecture that include abrupt and truncated facies boundaries in platform-toslope transition), thick debris flows, intraformational breccias, changes in isopachs, and synsedimentary slump structures indicates favorable stratigraphic horizons and can be used to vector toward structures that may have been ore-fluid conduits.

- Geochemical anomalies or zoning: On a local scale, increasing organic matter and pyrite and trace element concentrations (and ratios) in reduced sediments can be used as vectors toward areas favorable for ore. Hydrothermal alteration composed of Fe- and Mn-rich carbonate rocks or silicification (or both) allows identification of mineralizing faults on a local scale.

- Sedex deposits or occurrences: It is common for multiple sedex deposits to be distributed for many tens of kilometers along basin-controlling faults. Therefore, areas along large fault systems with evidence of mineralization should be viewed as very favorable for undiscovered deposits.

\section{Geoenvironmental Features}

\section{Weathering Processes}

Modern weathering processes that affect mine wastes from massive sulfide deposits are similar, in many respects, to those operating in the supergene environment after the initial formation of the mineral deposit, but there are important differences. Supergene alteration products such as anglesite, cerussite, hydrozincite, or hemimorphite are important indicator minerals that are useful in exploring for sedex deposits. Supergene alteration processes are driven by oxygen and oxygenated waters reacting with a sedex orebody; therefore, the thickness of the zone of supergene alteration is dependent on the depth and amount of fluctuation of the local water table. In humid climates, water tables are shallow and near the surface, resulting in a thin zone of supergene activity. In arid climates, water tables are deep, and oxygen and surface precipitation may percolate to depth, resulting in a thick zone of supergene alteration minerals. Oxides of iron, such as goethite or hematite, and sulfates, such as alunite and jarosite, are common surficial weathering products in gossans that overlie orebodies.

Acid-mine drainage is one of the most significant challenges associated with sedex deposits because of the abundance of pyrite, pyrrhotite, or both iron sulfides and the general lack of any significant neutralizing potential or alkalinity. The geochemistry of acid-mine drainage has been reviewed by Nordstrom and Alpers (1999), and additional aspects of the weathering of a variety of ore and gangue minerals were discussed by Plumlee (1999). Seal and others (2001a), Seal and Hammarstrom (2003), Seal (2004), and Kelley and others (1995) have previously reviewed the geoenvironmental characteristics of sedex and other types of massive sulfide deposits.

Geochemical aspects of the formation of acid-mine drainage and its burden of metals and other elements of concern reflect the balance between sulfide-oxidation reactions, which produce acid, and acid-neutralization reactions. The abundance of pyrite, and to a lesser extent pyrrhotite, in sedex ores dominates most aspects of the environmental behavior of the deposits and their mine wastes because of their acidgenerating potential. Pyrite is the most common iron-sulfide 
mineral in sedex ores, but the Sullivan deposit in British Columbia (Canada) is a notable example where pyrrhotite is important (Leach and others, 2005b). Acid generated by their oxidative weathering aggressively attacks other ore and gangue minerals, thereby liberating a variety of potentially toxic elements including aluminum and manganese, which are not part of the typical metallic ore assemblage, but instead are found in silicate and carbonate gangue minerals. The acidic, metal-laden acid-sulfate waters can adversely affect the surrounding surface waters and groundwater. Within the hydrologic system of mine workings and mine wastes, carbonate minerals, silicate minerals, and even monosulfide minerals such as sphalerite can neutralize acid generated by the oxidative weathering of iron sulfide minerals.

The oxidation of pyrite and other sulfide minerals proceeds with either dissolved oxygen $\left(\mathrm{O}_{2}\right)$ or dissolved ferric iron $\left(\mathrm{Fe}^{3+}\right)$ as the oxidizing agent. Dissolved oxygen is the most important oxidant at $\mathrm{pH}$ values above about 4 , whereas ferric iron dominates below that threshold (Williamson and others, 2006). The aqueous oxidation of pyrite $\left(\mathrm{FeS}_{2}\right)$ by dissolved oxygen is described by reaction 1 .

$$
\mathrm{FeS}_{2}+7 / 2 \mathrm{O}_{2}+\mathrm{H}_{2} \mathrm{O} \rightarrow \mathrm{Fe}^{2+}+2 \mathrm{SO}_{4}^{2-}+2 \mathrm{H}^{+}
$$

The aqueous oxidation of pyrrhotite $\left(\mathrm{Fe}_{1-x} \mathrm{~S}\right)$ by dissolved oxygen is described by reaction 2

$$
\mathrm{Fe}_{1-x} \mathrm{~S}+(2-x / 2) \mathrm{O}_{2}+x \mathrm{H}_{2} \mathrm{O} \rightarrow(1-x) \mathrm{Fe}^{2+}+\mathrm{SO}_{4}^{2-}+2 x \mathrm{H}^{+}
$$

where $x$ ranges from 0.000 to 0.125 .

The aqueous oxidation of pyrite by ferric iron is described by reaction 3 .

$$
\mathrm{FeS}_{2}+14 \mathrm{Fe}^{3+}+8 \mathrm{H}_{2} \mathrm{O} \rightarrow 15 \mathrm{Fe}^{2+}+2 \mathrm{SO}_{4}^{2-}+16 \mathrm{H}^{+}
$$

Where ferric iron is the oxidant, ferrous iron $\left(\mathrm{Fe}^{2+}\right)$ must be oxidized to ferric iron to perpetuate the reaction, as described by reaction 4 .

$$
\mathrm{Fe}^{2+}+1 / 4 \mathrm{O}_{2}+\mathrm{H}^{+} \rightarrow \mathrm{Fe}^{3+}+1 / 2 \mathrm{H}_{2} \mathrm{O}
$$

The rate of the oxidation of ferrous iron to ferric iron is greatly enhanced by the bacterium Acidithiobacillus ferrooxidans. Singer and Stumm (1970) observed that A. ferrooxidans increased the rate of oxidation of ferrous iron to ferric iron by a factor of 100,000 compared to the abiotic rate. In the case of both sets of reactions for pyrite and pyrrhotite, additional acid is generated by the oxidation and hydrolysis of the aqueous ferrous iron, as described by reaction 5

$$
\mathrm{Fe}^{2+}+1 / 4 \mathrm{O}_{2}+5 / 2 \mathrm{H}_{2} \mathrm{O} \rightarrow \mathrm{Fe}(\mathrm{OH})_{3}+2 \mathrm{H}^{+}
$$

which also produces the orange and brown precipitates that typify acid-mine drainage.
Pyrrhotite and other monosulfides, such as sphalerite $(\mathrm{ZnS})$, can also undergo non-oxidative dissolution under anoxic conditions when exposed to acid, as described by reactions 6 and 7, respectively.

$$
\begin{gathered}
\mathrm{Fe}_{1-x} \mathrm{~S}+(2-2 x) \mathrm{H}^{+}+x \mathrm{H}_{2} \rightarrow(1-x) \mathrm{Fe}^{2+}+\mathrm{H}_{2} \mathrm{~S} \\
\mathrm{ZnS}+2 \mathrm{H}^{+} \rightarrow \mathrm{Zn}^{2+}+\mathrm{H}_{2} \mathrm{~S}
\end{gathered}
$$

Reaction 6, with pyrrhotite, effectively decouples iron and sulfur oxidation, and both of these reactions consume acid. Sphalerite and pyrite in sedex ores can carry significant concentrations of trace elements in solid solution that can get liberated during weathering, as discussed in following sections.

Ore minerals, such as sphalerite, galena, and chalcopyrite, undergo similar reactions with dissolved oxygen and ferric iron serving as oxidants. Zinc and copper tend to go into solution, but lead commonly forms secondary phases such as anglesite $\left(\mathrm{PbSO}_{4}\right)$ or cerussite $\left(\mathrm{PbCO}_{3}\right)$, depending upon the concentrations of sulfate and carbonate in solution. These secondary phases can limit dissolved lead concentrations.

Gangue minerals in the host rocks generally react to consume the acid generated by the oxidation of sulfides. Silicate minerals are far less reactive than carbonate minerals (Jambor and others, 2002). Carbonate minerals can occur as trace constituents of silciclastic host rocks or as limestone host rocks. Carbonate minerals, such as calcite $\left(\mathrm{CaCO}_{3}\right)$, consume acid, as described by reaction 8 .

$$
\mathrm{CaCO}_{3}+\mathrm{H}^{+} \rightarrow \mathrm{Ca}^{2+}+\mathrm{HCO}_{3}^{-}
$$

Under anoxic conditions, siderite will neutralize acid, but the oxidation and hydrolysis of the resulting ferrous iron will offset the alkalinity produced.

\section{Pre-Mining Baseline Signatures in Soil, Sediment, and Water}

Mine permitting and remediation planning require documentation or an estimation of pre-mining baseline conditions, particularly for regulated media such as groundwater and surface water, soil, and sediment, to serve as a goal for post-mining reclamation. Detailed baseline geochemical characterization prior to the onset of mining is essential. Many abandoned mines, however, did not undergo baseline characterization prior to mining, so a variety of methods, all of which are problematic, have been used to estimate pre-mining backgrounds for abandoned mines (Runnells and others, 1992, 1998; Alpers and others, 1999; Alpers and Nordstrom, 2000).

Geochemical background data available in the literature for sedex deposits are dominated by data from unmined deposits or from samples collected prior to mining for several mineral deposits in Alaska. These geochemical data include analyses from stream sediment, soil, and surface water in the vicinity of the Red Dog, Drenchwater, and Lik deposits in the Brooks Range of northwestern Alaska (Kelley and others, 1992; Graham and others, 2009). 
Stream-sediment samples $(<0.2$-millimeter $[\mathrm{mm}]$ and $<0.5$-mm fractions) associated with sedex deposits in cold semiarid settings in northwestern Alaska contain anomalous concentrations of many metals, including as much as 10 milligrams per kilogram (mg/kg) Ag; tens of $\mathrm{mg} / \mathrm{kg} \mathrm{As}, \mathrm{Cd}$, and $\mathrm{Sb}$; hundreds of $\mathrm{mg} / \mathrm{kg} \mathrm{Cu}$ and $\mathrm{Ni}$; thousands of $\mathrm{mg} / \mathrm{kg} \mathrm{Mn}, \mathrm{Pb}$, and $\mathrm{Zn}$; and hundreds of thousands of $\mathrm{mg} / \mathrm{kg} \mathrm{Ba}$ (Theobald and others, 1978; Kelley and others, 1992). Soil that overlies mineralized rock, such as at the Red Dog and Lik deposits in the Brooks Range, Alaska, contains hundreds to tens of thousands of $\mathrm{mg} / \mathrm{kg} \mathrm{Pb}$, hundreds to thousands of $\mathrm{mg} / \mathrm{kg} \mathrm{Ba}$ and $\mathrm{Zn}$, tens of $\mathrm{mg} / \mathrm{kg} \mathrm{Ag}$, and tens to hundreds of $\mathrm{mg} / \mathrm{kg} \mathrm{Cu}$, but concentrations of other metals, including less than $2 \mathrm{mg} / \mathrm{kg} \mathrm{Cd}$, hundreds of $\mathrm{mg} / \mathrm{kg}$ $\mathrm{Mn}$, and tens of $\mathrm{mg} / \mathrm{kg} \mathrm{Ni}$, are low relative to stream-sediment abundances (Briggs and others, 1992; Meyer and Kurtak, 1992; Kelley and Kelley, 2003; Kelley and Hudson, 2007). Soil overlying sedex deposits in warm semiarid settings in Australia similarly contains hundreds to thousands of $\mathrm{mg} / \mathrm{kg} \mathrm{Cu}, \mathrm{Pb}$, and $\mathrm{Zn}$ and tens of $\mathrm{mg} / \mathrm{kg} \mathrm{Ag}$ (Cox and Curtis, 1977).

The availability of atmospheric oxygen and the position of the groundwater table are two of the most important factors in determining the natural weathering behavior of sedex deposits. Therefore, these factors greatly influence water chemistry. Surface waters surrounding exposed deposits generally are more acidic and carry more dissolved metals than those draining buried deposits. The Alaskan sedex deposits-Red Dog, Lik, and Drenchwater - are exposed at the surface. Mining started at Red Dog in 1989, and reserves have been identified sufficient to continue mining until 2031. Neither Drenchwater nor Lik has been developed to date. The available data for water associated with these deposits have a range of $\mathrm{pH}$ from approximately 3 to 9 and a range of concentrations of dissolved iron from approximately less than 0.02 to $300 \mathrm{mg} / \mathrm{L}$ (fig. 14). The natural weathering of these rocks has caused elements of concern for aquatic ecosystem health, such as $\mathrm{Fe}, \mathrm{Zn}, \mathrm{Cd}$, and $\mathrm{Pb}$, to reach concentrations in excess of generic water-quality guidelines for the protection of aquatic life (fig. 14). The presence of these elevated concentrations in the vicinity of the Red Dog, Drenchwater, and Lik deposits prior to the start of any mining activity underscores the importance of pre-mining baseline characterization to aid in establishing closure goals for the end of mining.

\section{Past and Future Mining Methods and Ore Treatment}

Mining methods and ore-beneficiation techniques significantly influence the potential environmental impacts of sedex deposits. Both open-pit (for example, Red Dog, Alaska, and Faro, Yukon Territory, Canada) and underground (for example, Sullivan, British Columbia, Canada) methods have been used to mine sedex deposits in historical and modern operations. The hydrologic differences between underground and open-pit mines are significant, particularly at abandoned mines.
Mineral processing causes a number of physical and chemical changes to the ore from which the metal concentrates are produced. Most sedex massive sulfide deposits contain a large excess of iron-sulfide minerals relative to valuable base-metal sulfide minerals. The nature of ore processing and the method of disposal of the sulfide-mineral-rich tailings and waste rocks are critical parameters that influence the scope of environmental impacts associated with mining massive sulfide deposits. Some modern mines discharge fine-grained sulfide-rich tailings into ponds underlain by impermeable linings, but historical tailings impoundments generally lack impermeable barriers at the base.

Base-metal sulfide minerals are typically separated by froth flotation. The exact mix of flotation reagents will depend on the mineralogical character of the ores being processed and includes chemicals known as frothers, modifiers, and collectors to target specific minerals in the ores (Fuerstenau and others, 2007). Xanthates and dithiophosphates are some of the most common collectors used for base-metal ores, such as those from sedex deposits. The most important frothers are alcohols and short-chain aliphatic alcohols and polyglycols. Modifiers include inorganic compounds, oligomers and small organic compounds, and polymeric organic compounds that modify a variety of solution properties such as $\mathrm{pH}$ and pulp potential. Some of the reagents used in the process are toxic, but most are recycled and only relatively minor amounts are discharged to tailings facilities. Because of the recycling of process waters and the compaction of tailings, long-term risks from tailing piles associated with these chemicals should be minimal.

The fine grain size, the typically large volume of tailing piles, and the oxygen consumption of waste sulfide minerals establish distinct geochemical environments in tailings piles. The fine grain size enhances the reactivity of the sulfide and gangue minerals by increasing surface area, though in some instances it also facilitates the formation of hardpan layers that can act as semipermeable to impermeable barriers to oxygen diffusion, thus limiting sulfide oxidation (Blowes and others, 1991, 2003). Numerous studies of tailings from massive sulfide ores indicate that the $\mathrm{pH}$ of pore waters in the unsaturated and saturated zones of tailings piles is generally buffered by a predictable series of solid phases. Commonly, pore waters show a step-decrease in $\mathrm{pH}$ from $6.5-7.5$, to $4.8-6.3$, to $4.0-4.3$, and finally to less than 3.5 , which corresponds to buffering by calcite, siderite, $\mathrm{Al}(\mathrm{OH})_{3}$, and $\mathrm{Fe}(\mathrm{OH})_{3}$, respectively (Blowes and Ptacek, 1994; Jurjovec and others, 2002; Blowes and others, 2003).

\section{Volume of Mine Waste and Tailings}

Most economic sedex deposits are between 1.4 and $120 \mathrm{Mt}$; the median deposit size is $15 \mathrm{Mt}$ (Menzie and Mosier, 1986). The Howards Pass deposit, Yukon Territory, contains an estimated $550 \mathrm{Mt}$ of ore (Goodfellow and others, 1993). Because ore grades typically reach several percent at most, the tonnage of tailings is similar to the tonnage of ore. However, the amount of waste rock will vary on the basis of mining method. Open-pit mines may need to strip significant amounts 

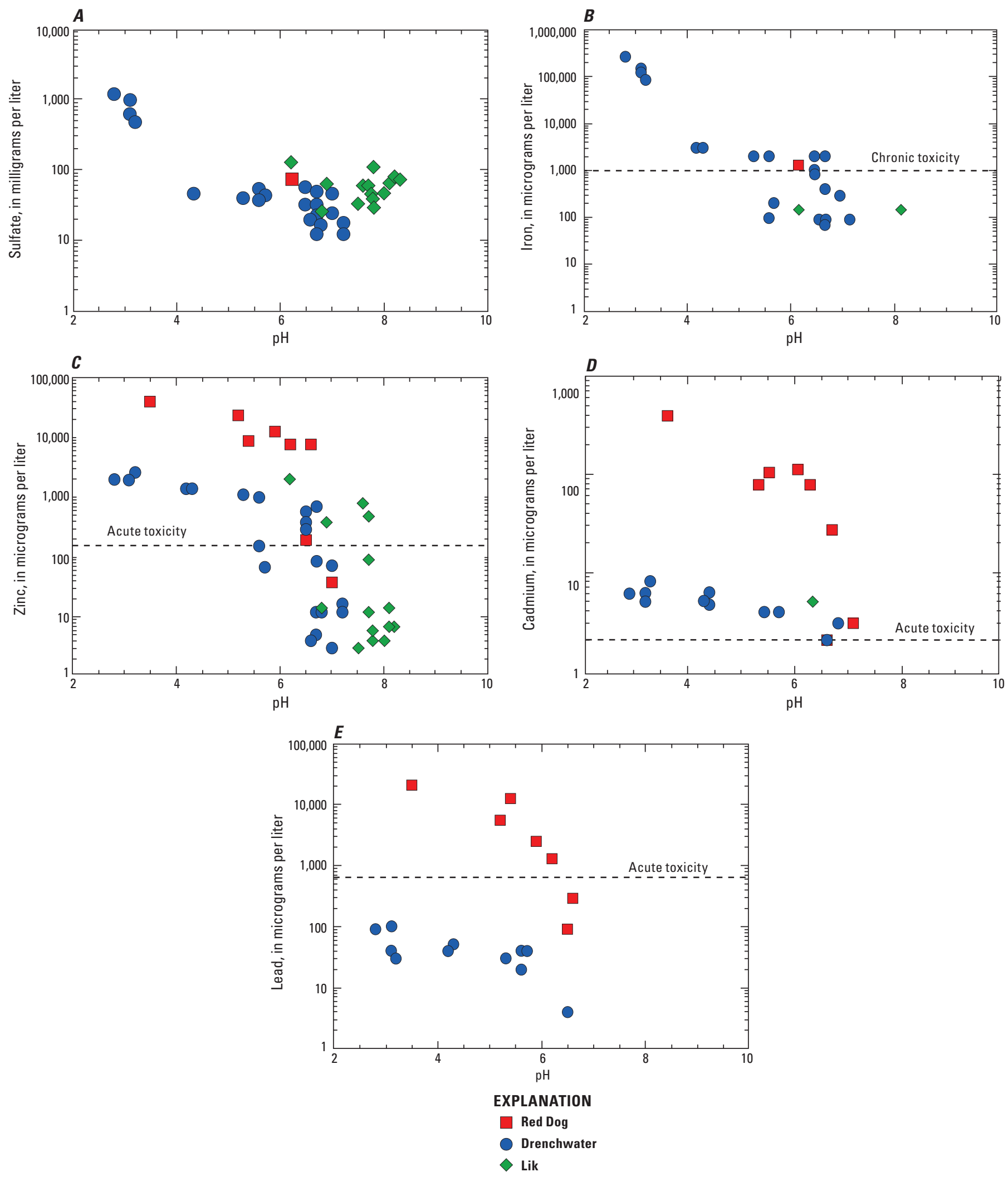

Figure 14. Geochemical data for waters associated with unmined sedex massive sulfide deposits: the Red Dog, Drenchwater, and Lik deposits. Data from Kelley and Taylor (1997). A, Dissolved sulfate $\left(\mathrm{SO}_{4}\right)$ and $\mathrm{pH}$. B, Dissolved iron and pH. C, Dissolved zinc and $\mathrm{pH}$. $D$, Cadmium and pH. E, Dissolved lead and pH. U.S. Environmental Protection Agency (2006) acute and chronic water-quality guidelines for the protection of aquatic organisms are shown for reference. Hardness-dependent guidelines (zinc, cadmium, and lead) were calculated assuming a water hardness of 100 milligrams per liter as calcium carbonate. 
of subeconomic, but potentially problematic, waste rock, whereas the amount of waste rock generated by underground mines is typically less. For example, approximately $140 \mathrm{Mt}$ of ore have been mined at the Sullivan mine, British Columbia, and 90 million tonnes of siliceous tailings containing sulfide mineral waste cover about 373 hectares of land (O'Kane and Ryland, 1999). As another example, the mass of tailings to be impounded by closure at the Red Dog mine, Alaska, is estimated to be $80 \mathrm{Mt}$ (TeckCominco, 2007).

\section{Mine Waste Characteristics}

\section{Mineralogy}

From an environmental perspective, the most important mineralogical characteristics of sedex massive sulfide ore and mine waste are those that relate to acid-generating potential, acid-neutralizing potential, and the source, transport, and fate of trace elements. Sedex deposits are collectively defined by the fact that they formed syngenetically on or near the ancient sea floor through hot-spring activity as lenslike or tabular bodies of stratiform sulfide minerals, dominantly pyrite or pyrrhotite. By definition, the deposits contain massive zones of sulfide minerals - many with sulfide-mineral contents exceeding 90 vol. percent. Many deposits also contain extensive zones of semimassive sulfide rock (25-50 vol. percent) that contain economically exploitable ore. Quartz- or carbonate-rich stringer ore zones in the footwall of the massive sulfides typically contain 5-20 vol. percent sulfide minerals hosted in quartz veins and disseminated in chloritic wall rocks. The primary ore mineralogy defines the suite of metals that may cause potential environmental problems. In addition to pyrite and pyrrhotite, the ore minerals sphalerite $(\mathrm{ZnS})$ and galena $(\mathrm{PbS})$ are commonly major constituents in these deposits. These minerals, and their weathering products, are the principal sources of elevated concentrations of zinc and lead, among other elements, in mine waste and drainage. Kelley and others (2004b) investigated the trace element chemistry of sphalerite and pyrite from the Red Dog mine, Alaska. In sphalerite, they found Fe concentrations reaching 7.3 wt. percent, $\mathrm{Cd}$ reaching 1.0 wt. percent, As reaching 0.2 wt. percent, $\mathrm{Pb}$ reaching $1.0 \mathrm{wt}$. percent, and $\mathrm{Hg}$ reaching $0.4 \mathrm{wt}$. percent. Schwartz (1997) observed that sphalerite has higher Hg concentrations in Proterozoic sedimentary exhalative deposits such as Broken Hill, Australia, and Balmat, New York, United States $(4-4,680 \mathrm{mg} / \mathrm{kg})$ than in deposits such as Faro, Canada, and Rammelsberg and Meggan, Germany $(0.3-548 \mathrm{mg} / \mathrm{kg})$. In pyrite from the Red Dog deposit, Kelley and others (2004b) found significant concentrations of As ( $<1.1 \mathrm{wt}$. percent), Co ( $<0.1$ wt. percent), $\mathrm{Cu}(<0.2$ wt. percent), $\mathrm{Ni}(<0.2$ wt. percent), $\mathrm{Tl}(<1.2$ wt. percent), and $\mathrm{Sb}(<0.7$ wt. percent). The primary mineralogical characteristics of sedex and other types of massive sulfide deposits are summarized in table 1.

Various carbonate minerals, most of which contribute neutralizing potential, are associated locally with primary alteration assemblages of some of these deposit types in minor amounts. Calcite and ankerite dominate the carbonate mineralogy.
Sedex deposits may have dolomitic shales in their host rocks, and siderite, which has no net neutralizing potential, in their alteration assemblages.

The secondary mineralogy associated with the weathering of a deposit or its mine wastes tends to sequester metals, acidity, or both on either a long-term or short-term basis. Hydrated ferric oxides can sorb metals on a somewhat refractory substrate, whereas efflorescent metal sulfate salts, such as melanterite, serve as a means of stored metals and acidity during dry periods. These salts readily dissolve during rainstorms or spring snowmelt and thus deliver their metals and acidity to the surrounding watershed. Secondary minerals also have important implications for acid-base accounting. General secondary mineralogical features of sedex and other types of massive sulfide deposits are summarized in table 1.

Secondary minerals associated with sedex deposits include goethite, crystalline and amorphous silica, schwertmannite, jarosite, native silver, barite, anglesite, cerussite, litharge, and acanthite (Kelley and others, 1995). Anglesite and cerussite are the most abundant secondary lead minerals, but coronadite, mimetite, nadorite, pyromorphite, and lanarkite have also been reported (Kelley and others, 1995). Secondary zinc minerals are rare, with the exception of goslarite.

\section{Acid-Base Accounting}

The primary and secondary mineralogy of the ores, their solid mine wastes, and associated rock types define the acid-generating and acid-neutralizing potential of the waste in a procedure known as acid-base accounting (ABA). A series of static-test methods has been developed to predict the acid-generating potential of mine wastes as a tool to assist in waste management. Use of these tests is known as acidbase accounting or ABA (Sobek and others, 1978; White and others, 1999), which is discussed in detail by Jambor (2003). Acid-base accounting is based on the stoichiometric reaction

$$
\begin{aligned}
\mathrm{FeS}_{2} & +2 \mathrm{CaCO}_{3}+3.75 \mathrm{O}_{2}+1.5 \mathrm{H}_{2} \mathrm{O} \\
& \rightarrow \mathrm{Fe}(\mathrm{OH})_{3}+2 \mathrm{SO}_{4}^{2-}+2 \mathrm{Ca}^{2+}+2 \mathrm{CO}_{2}(\mathrm{~g})
\end{aligned}
$$

which is simply the sum of reactions 1 and 8 to eliminate $\mathrm{H}^{+}$as a constituent. It describes acid generation through the oxidation of pyrite $\left(\mathrm{FeS}_{2}\right)$ and subsequent neutralization by calcite $\left(\mathrm{CaCO}_{3}\right)$ (Sobek and others, 1978). In the case of some sedex massive sulfide deposits, most notably Sullivan, British Columbia, pyrrhotite $\left(\mathrm{Fe}_{1-x} \mathrm{~S}\right.$, where $x$ ranges from 0.000 to 0.106 ) is the dominant sulfide mineral. For pyrrhotite, acid-base accounting can be approximated by the simplified stoichiometric reaction

$$
\begin{aligned}
\mathrm{Fe}_{1-x} \mathrm{~S} & +\mathrm{CaCO}_{3}+2.25 \mathrm{O}_{2}+1.5 \mathrm{H}_{2} \mathrm{O} \\
& \rightarrow \mathrm{Fe}(\mathrm{OH})_{3}+\mathrm{SO}_{4}^{2-}+\mathrm{Ca}^{2+}+\mathrm{CO}_{2}(\mathrm{~g})
\end{aligned}
$$

The stoichiometry of calcite $\left(\mathrm{CaCO}_{3}\right)$ per unit to total sulfur is the same as in reaction 9, but the total sulfur per unit of solid will be lower because pyrrhotite has approximately half of the sulfur of pyrite. 
Table 1. Selected common mineralogical characteristics of sedimentary-exhalative deposits with a comparison to volcanic-hosted massive sulfide deposits.

[X, major characteristic; $\mathrm{x}$, minor characteristic; -, not reported]

\begin{tabular}{|c|c|c|c|c|c|c|}
\hline \multirow[b]{2}{*}{ Mineral } & \multirow{2}{*}{$\begin{array}{l}\text { Sedimentary- } \\
\text { exhalative } \\
\text { deposits }\end{array}$} & \multicolumn{5}{|c|}{ Volcanogenic massive sulfide deposits } \\
\hline & & $\begin{array}{c}\text { Mafic-ultra- } \\
\text { mafic }\end{array}$ & $\begin{array}{c}\text { Bimodal- } \\
\text { mafic }\end{array}$ & $\begin{array}{c}\text { Bimodal- } \\
\text { felsic }\end{array}$ & $\begin{array}{c}\text { Siliciclastic- } \\
\text { mafic }\end{array}$ & $\begin{array}{c}\text { Siliciclastic- } \\
\text { felsic }\end{array}$ \\
\hline \multicolumn{7}{|c|}{ Primary sulfide minerals } \\
\hline Pyrrhotite & $X, x$ & $\mathrm{x}$ & $X, x$ & $\mathrm{x}$ & $\mathrm{X}$ & $\mathrm{X}$ \\
\hline Chalcopyrite & $\mathrm{x}$ & $\mathrm{X}$ & $\mathrm{X}$ & $\mathrm{X}$ & $\mathrm{X}$ & $\mathrm{X}$ \\
\hline Sphalerite & $X$ & $\mathrm{x}$ & $X$ & $\mathrm{X}$ & $\mathrm{x}$ & $\mathrm{X}$ \\
\hline Tetrahedrite-tennantite & $\mathrm{x}$ & - & $\mathrm{x}$ & $\mathrm{x}$ & - & - \\
\hline Cinnabar & $\mathrm{x}$ & - & - & - & - & - \\
\hline \multicolumn{7}{|c|}{ Primary sulfate minerals } \\
\hline Anhydrite & $\mathrm{X}$ & - & - & $\mathrm{X}$ & - & - \\
\hline Barite & $\mathrm{X}$ & - & $\mathrm{X}$ & $\mathrm{X}$ & - & $\mathrm{X}$ \\
\hline \multicolumn{7}{|c|}{ Primary carbonate minerals } \\
\hline \multicolumn{7}{|c|}{ Primary oxide minerals } \\
\hline Magnetite & $\mathrm{x}$ & $\mathrm{x}$ & $\mathrm{x}$ & $\mathrm{x}$ & - & $\mathrm{x}$ \\
\hline Hematite & - & $\mathrm{x}$ & $\mathrm{x}$ & $\mathrm{x}$ & - & - \\
\hline \multicolumn{7}{|c|}{ Secondary sulfide minerals } \\
\hline Marcasite & $\mathrm{x}$ & - & $\mathrm{x}$ & $\mathrm{x}$ & $\mathrm{x}$ & - \\
\hline Covellite & - & - & $\mathrm{x}$ & $\mathrm{x}$ & $\mathrm{x}$ & - \\
\hline Chalcocite & - & $\mathrm{x}$ & $\mathrm{x}$ & - & $\mathrm{x}$ & - \\
\hline Enargite & - & - & $\mathrm{x}$ & $\mathrm{x}$ & - & - \\
\hline \multicolumn{7}{|c|}{ Secondary sulfate minerals } \\
\hline Gypsum & $\mathrm{x}$ & - & $\mathrm{x}$ & $\mathrm{x}$ & $\mathrm{x}$ & - \\
\hline Barite & - & - & $\mathrm{x}$ & $\mathrm{x}$ & - & - \\
\hline Melanterite/Rozenite & $\mathrm{x}$ & $\mathrm{x}$ & $\mathrm{x}$ & $\mathrm{x}$ & $\mathrm{x}$ & - \\
\hline Siderite & - & - & - & - & - & - \\
\hline Cerussite & $\mathrm{x}$ & - & - & - & - & - \\
\hline \multicolumn{7}{|c|}{ Secondary oxyhydroxide minerals } \\
\hline Ferrihydrite & $\mathrm{x}$ & $\mathrm{x}$ & $\mathrm{x}$ & - & $\mathrm{x}$ & - \\
\hline Goethite & $\mathrm{x}$ & $\mathrm{x}$ & $\mathrm{x}$ & - & $\mathrm{x}$ & - \\
\hline Schwertmannite & - & $\mathrm{x}$ & $\mathrm{x}$ & - & $\mathrm{x}$ & - \\
\hline Jarosite & - & - & $\mathrm{x}$ & - & $\mathrm{x}$ & - \\
\hline Amorphous $\mathrm{Al}(\mathrm{OH})_{3}$ & - & - & - & - & - & - \\
\hline Basaluminite & - & - & - & $\mathrm{x}$ & $\mathrm{x}$ & - \\
\hline Jurbanite & - & - & - & - & - & - \\
\hline
\end{tabular}


From an ABA perspective, sulfide minerals such as pyrite, pyrrhotite, chalcopyrite, and sphalerite dominate the primary ore mineralogy of these deposits and contribute to the maximum potential acidity. Secondary metal-sulfate salts that commonly accumulate as intermediate products of sulfide oxidation also will contribute acidity (Alpers and others, 1994; Cravotta, 1994; Hammarstrom and others, 2001). For example, melanterite $\left(\mathrm{FeSO}_{4} \cdot 7 \mathrm{H}_{2} \mathrm{O}\right)$, rozenite $\left(\mathrm{FeSO}_{4} \cdot 4 \mathrm{H}_{2} \mathrm{O}\right)$, copiapite $\left(\mathrm{Fe}^{2+} \mathrm{Fe}_{4}^{3+}\left(\mathrm{SO}_{4}\right)_{6}(\mathrm{OH})_{2} \cdot 2 \mathrm{H}_{2} \mathrm{O}\right)$, and halotrichite $\left(\mathrm{Fe}^{2+} \mathrm{Al}_{2}\left(\mathrm{SO}_{4}\right)_{4} \cdot 22 \mathrm{H}_{2} \mathrm{O}\right)$, among others, are common and highly soluble; less soluble sulfate minerals such as jarosite and schwertmannite $\left(\mathrm{Fe}_{8} \mathrm{O}_{8}\left(\mathrm{SO}_{4}\right)(\mathrm{OH})_{6}\right)$ also are common in mining environments (table 1 ). In contrast, the alkaline-earth sulfate minerals, such as barite, anhydrite, and gypsum, also are common as both primary and secondary minerals associated with sedex deposits (table 1), but they do not contribute acidity although their sulfur content will be reported in determinations of total sulfur. The most prominent differences in secondary sulfate-mineral speciation among mine wastes from sedex massive sulfide deposits are in their jarosite and metal-sulfate salts, particularly in the presence or absence of goslarite $\left(\mathrm{ZnSO}_{4} \cdot 7 \mathrm{H}_{2} \mathrm{O}\right)$ and alunogen $\left(\mathrm{Al}_{2}\left(\mathrm{SO}_{4}\right)_{3} \cdot 17 \mathrm{H}_{2} \mathrm{O}\right)$. Modifications to the original ABA procedures attempt to accommodate these problems (White and others, 1999).

The acid-base account of a sample is expressed in terms of an acid-generating potential (AP) and an acid-neutralizing potential (NP), both expressed in terms of kilograms of calcium carbonate per metric ton of material $\left(\mathrm{kg} \mathrm{CaCO}_{3} / \mathrm{t}\right)$. The acid-base account can be expressed in terms of a net neutralization potential (NNP), defined as

$$
\mathrm{NNP}=\mathrm{NP}-\mathrm{AP} .
$$

Therefore, a negative NNP value corresponds to a sample where the acid-generating potential is greater than the acidneutralizing potential; it is designated as being net acidic. A positive NNP value is designated as being net alkaline. Alternatively, the acid-base account can be expressed in terms of a neutralizing potential ratio (NPR), defined as

$$
\mathrm{NPR}=\mathrm{NP} / \mathrm{AP}
$$

such that an NPR value below one is net acidic and a value above one is net alkaline.

Net neutralization potentials for tailings from sedex deposits are generally net acidic. A single sample of tailings from the Faro mine, Yukon Territory, Canada, has a highly acidic net neutralization potential of $-688 \mathrm{~kg} \mathrm{CaCO}_{3} / \mathrm{t}$ and a paste $\mathrm{pH}$ of 2.9 (Seal and others, 2009). Additional data for waste rock from Faro are provided by Gartner Lee Limited $(2006,2007)$. The acid-base accounting characteristics of waste rocks and tailings from the Faro (Yukon Territory, Canada) and the Red Dog (Alaska) deposits are summarized in figure 15. The range of waste-rock types at Red Dog range from net alkaline (NP:AP $>1$ ) to net acidic (NP:AP $<1)$. The waste rock from Faro ranges from net neutral (NP:AP 1) to net acidic. For both deposits, the tailings have high acidgenerating potential (NP:AP $<<1$ ).

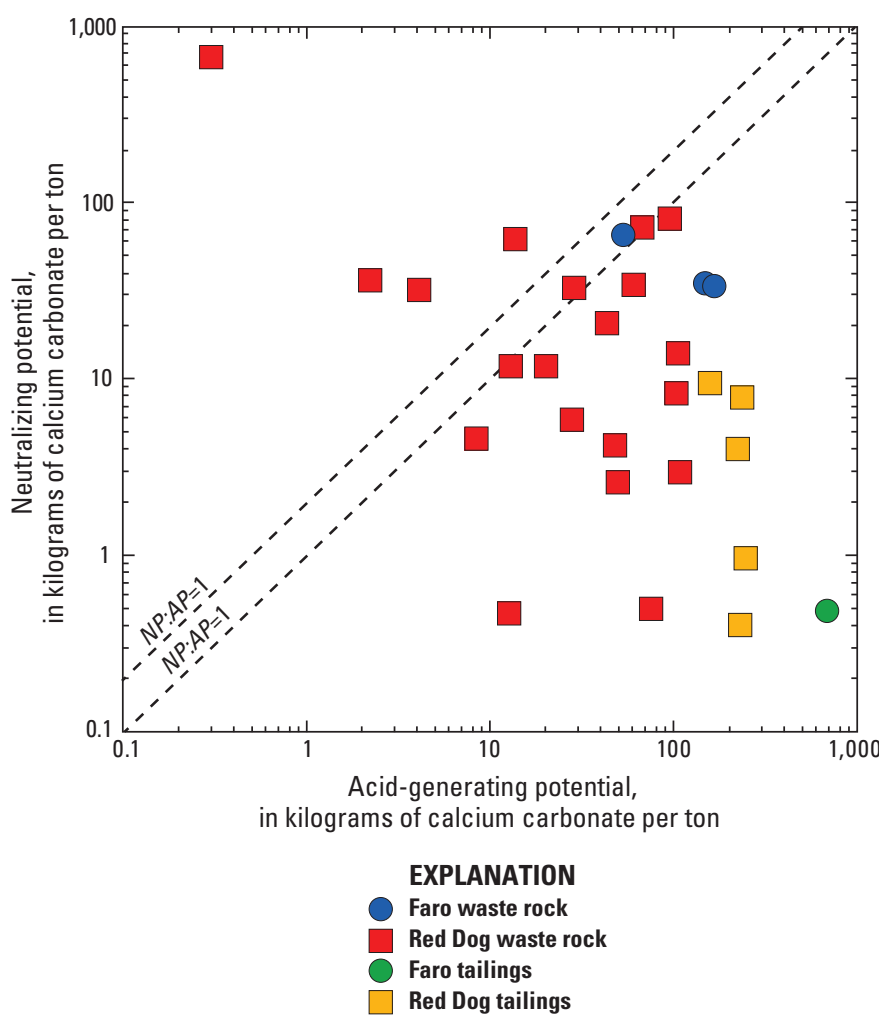

Figure 15. Acid-base accounting characteristics of waste rock and tailing for the Faro and Red Dog sedex deposits. Measured acid-neutralizing potential (NP) values are plotted against the acid-generating potential (AP) values for the samples. Samples with NP:AP values less than 1 are considered to be "probably acid-drainage generating" (PAG) samples; those with NP:AP values greater than 2 are considered to be "non-probably acid-drainage generating" (non-PAG) samples; and those with NP:AP values between 1 and 2 are considered to have "uncertain" acid-drainage generating potential.

\section{Element Mobility Related to Mining in Groundwater and Surface Water}

The quality of mine drainage is controlled by the geological characteristics of the mineral deposit modified by the combined effects of the mineralogy, the mining and orebeneficiation methods used, the hydrologic setting of the mine workings and waste piles, and climate. Data are available from several sedex deposits in different climatic settings.

Mine-drainage data are available for sedex deposits at the Faro mine in the Yukon Territory, Canada (Gartner Lee, 2006, 2007); the Red Dog mine in Alaska, United States (Tetra Tech, 2009); and the Troya mine, a carbonate hosted deposit, in Spain (Marqués and others, 2001). Data for Faro, an abandoned mine, include groundwater and surface-water geochemical data. The surface-water samples include pit water, drainage from waste and tailing piles, and major streams draining the area. Much of the drainage leaving the site is being treated prior to discharge while long-term remedial options are being evaluated. Data from Red Dog, an active mine, are from 
monitoring sites around the active mine, and data from Troya, an inactive mine that has not been remediated, are from waters in and around the mine.

Mine drainage associated with sedex deposits shows a general, negative correlation between dissolved metals and $\mathrm{pH}$ for sulfate and most metals, such as $\mathrm{Fe}$, aluminum ( $\mathrm{Al}), \mathrm{Cu}$, $\mathrm{Zn}, \mathrm{Ni}, \mathrm{Co}, \mathrm{Cd}$, and $\mathrm{Pb}$. The $\mathrm{pH}$ of these mine waters generally ranges between 5.5 and 8.5 , which is a reflection of water treatment at Faro and Red Dog and of the neutralization of acid by carbonate host rocks at Troya. The low $\mathrm{pH}$ values seen at Faro generally represent surface waters and groundwaters that are upgradient from treatment facilities (fig. 16). Iron is typically a dominant cation, and sulfate is the dominant anion (figs. $16 \mathrm{~A}, \mathrm{~B}$ ). The correlations among $\mathrm{pH}$, metals, and sulfate reflect acid generation dominantly through the aqueous, oxidative weathering of pyrite and associated ore sulfides. For the divalent metals, iron and aluminum, mine-drainage compositions overlap significantly with natural background compositions but extend to higher metal concentrations and lower $\mathrm{pH}$ values (figs. 14, 16). Increases in total dissolved base metals and iron in mine drainage generally correlate with increases in pyrite content, decreases in acid-neutralizing capacity, and increases in base-metal content of the waste material (Plumlee and others, 1999). The presence of anoxic conditions in tailings and other waste piles, however, may result in seepage waters that have high concentrations of iron at near-neutral $\mathrm{pH}$ values because the iron is predominantly in the more soluble ferrous state than in the less soluble ferric state (Seal and others, 2001b). This effect can be seen at Faro, where the groundwater concentrations for dissolved iron are higher than those for surface water at equivalent $\mathrm{pH}$ values.

The geochemistry of mine drainage from sedex deposits shows clear evidence of primary controls based on deposit type, as well as mineralogical controls for individual metals (Seal and Hammarstrom, 2003). In terms of dissolved $\mathrm{Cu}$ and $\mathrm{Zn}$, the metals correlate positively, with sedex deposit types falling at distinctly high ranges of $\mathrm{Zn}: \mathrm{Cu}$ ratios compared to most other types of massive sulfide deposits (fig. 17). The ratios of the metals dissolved in drainage waters are directly related to the primary chemical composition of the ores. The $\mathrm{Zn}: \mathrm{Cu}$ ratios (mass basis) for waters associated with sedex deposits range from approximately 10:1 to 1,000:1.

Drainage compositions associated with sedex deposits further illustrate the importance of pre-mining baseline characterization. The pre-mining water-chemistry data available for the Alaskan deposits Red Dog, Lik, and Drenchwater reflect the predominance of siliciclastic host rocks through the low $\mathrm{pH}$ values found in some samples; as discussed above, many of these samples have concentrations of trace metals that exceed water-quality guidelines for the protection of aquatic organisms (Kelley and Taylor, 1997). Mine water on the site can also exceed water-quality guidelines. For example, water pumped from the pit at Red Dog during current mining typically has a $\mathrm{pH}$ of approximately 3.5 , TDS between 7 and 14 grams per liter $(\mathrm{g} / \mathrm{L})$, dissolved $\mathrm{Zn}$ between 1 and $2 \mathrm{~g} / \mathrm{L}$, dissolved Fe between 250 and $1,000 \mathrm{mg} / \mathrm{L}$, and elevated concentrations of total As, $\mathrm{Cd}$, and $\mathrm{Cu}$ (Tetra Tech, 2009). Surface water from monitoring sites around the active mine shows a significantly more restricted range of $\mathrm{pH}$ values (16 to 17 ; fig. 16) than pre-mining samples from the Brooks Range deposits ( 2.5 to 8.5 ; fig. 3 ). The range of dissolved metal concentrations locally can exceed the generic water-quality guidelines (fig. 16), but the range of values is essentially the same as natural pre-mining conditions (fig. 14).

Water-chemistry data available for the Troya deposit, Spain, are for mine drainage from a deposit hosted by carbonate rocks. Despite having been disturbed by mining, the drainage from Troya has a higher $\mathrm{pH}$ and lower base-metal concentrations than the pre-mining drainage surrounding the Red Dog deposit (figs. 14, 16). The neutral $\mathrm{pH}$ associated with mine drainage from Troya clearly reflects the influence of the carbonate host rocks. In contrast, the lower $\mathrm{pH}$ and higher metal concentrations of background waters surrounding Red Dog highlight the combined effects of limited acid-neutralizing potential of the black shale host rocks and enhanced sulfide weathering due to surface exposure of a massive sulfide body.

\section{Pit Lakes}

Studies of pit lakes associated with sedex deposits have not been identified. However, hypothetical pit-water quality at Red Dog has been estimated from current mine-sump water quality (Tetra Tech, 2009). Representative concentrations of the Main Pit Sump at Red Dog have a range of $\mathrm{pH}$ from 3 to 5, TDS from 3.3 to $11.2 \mathrm{~g} / \mathrm{L}$, sulfate from 1.9 to $7.4 \mathrm{~g} / \mathrm{L}$, total As of as much as $0.98 \mathrm{mg} / \mathrm{L}$, total $\mathrm{Cd}$ from 3 to $99 \mathrm{mg} / \mathrm{L}$, total $\mathrm{Cu}$ from 0.19 to $3.8 \mathrm{mg} / \mathrm{L}$, total $\mathrm{Pb}$ from 0.5 to $47 \mathrm{mg} / \mathrm{L}$, and total Zn from 336 to $11,200 \mathrm{mg} / \mathrm{L}$.

\section{Ecosystem Issues}

Ecosystem risks associated with sedex deposits are predominantly from acid-mine drainage, which targets aquatic environments, and associated dissolved trace elements, principally $\mathrm{Fe}, \mathrm{Zn}, \mathrm{Cd}$, and $\mathrm{Pb}$. The oxidative weathering of pyrite $\left(\mathrm{FeS}_{2}\right)$ is described by above reactions 1 to 5 . The lower $\mathrm{pH}$ values generated by the oxidation of pyrite enhance the solubility of base metals such as $\mathrm{Cu}, \mathrm{Zn}, \mathrm{Cd}, \mathrm{Co}, \mathrm{Ni}$, and $\mathrm{Pb}$, and the ability of the solutions to attack silicate-gangue minerals, thus liberating $\mathrm{Al}, \mathrm{Mn}$, and other elements. Most metals show greater solubility at lower $\mathrm{pH}$, but aluminum and ferric iron have solubility minima at circum-neutral $\mathrm{pH}$, with greater solubility at both lower and higher $\mathrm{pH}$. Once liberated, the metals and acidity can affect downstream aquatic ecosystems. Metal contamination can also be dispersed downstream by the erosion and $t$ ransport of tailings, which subsequently release metals to the water column.

The toxicity of the metals to aquatic ecosystems is dependent on water hardness; higher concentrations of metals are needed to exceed toxicity limits at higher hardness values (U.S. Environmental Protection Agency, 2006). Hardness is a 

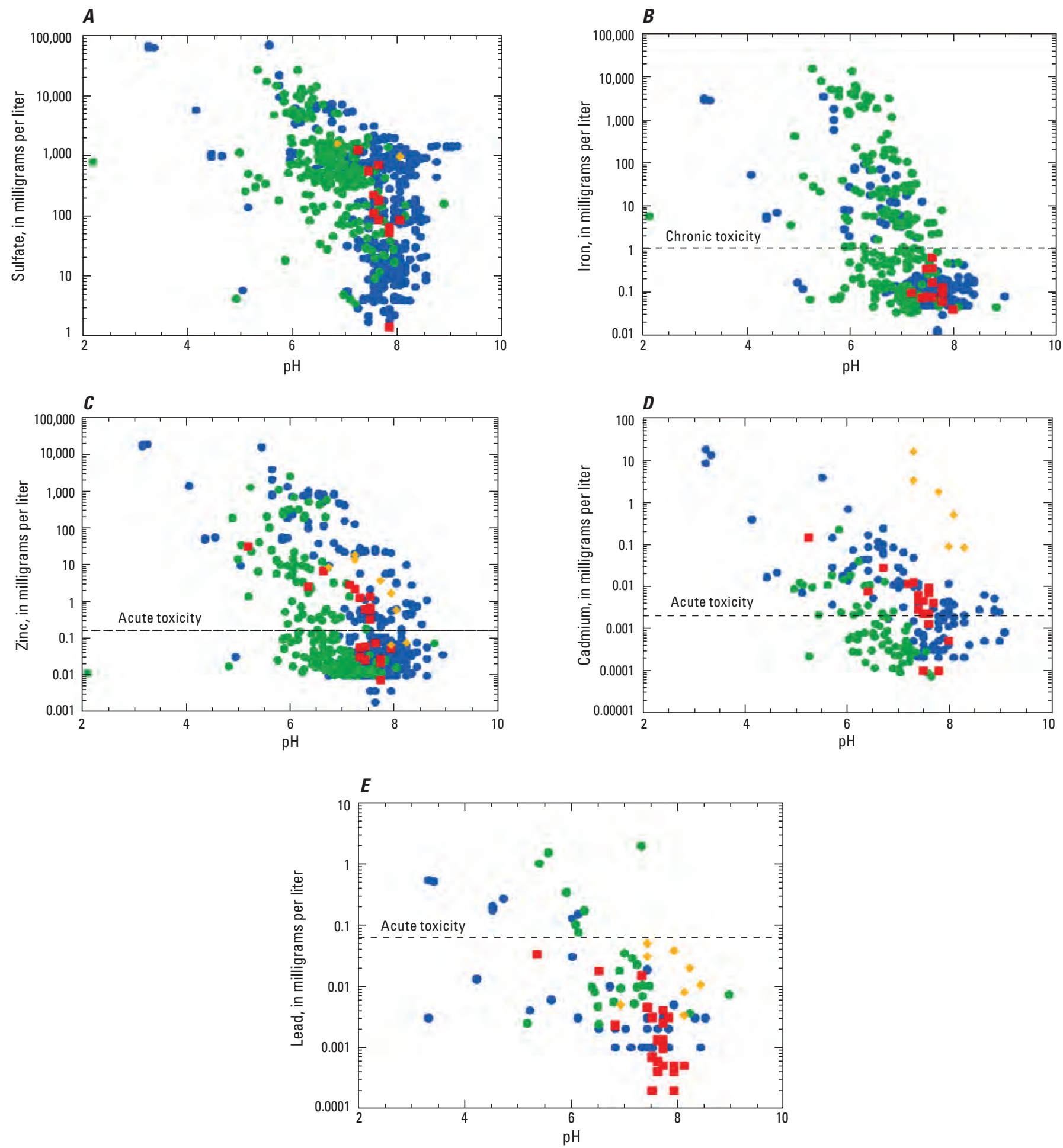

EXPLANATION

- Faro surface water Red Dog surface water

Figure 16. Geochemical data for waters associated with unmined sedex massive sulfide deposits: the Red Dog, Faro, and Troya mine deposits. Data for the Red Dog deposit from Tetra Tech (2009), the Faro deposit from Gartner Lee (2006, 2007), and the Troya mine from Marqués and others (2001). $A$, Dissolved sulfate $\left(\mathrm{SO}_{4}\right)$ and $\mathrm{pH}$. $B$, Dissolved iron and $\mathrm{pH}$. $C$, Dissolved zinc and $\mathrm{pH}$. $D$, Cadmium and $\mathrm{pH}$. $E$, Dissolved lead and pH. U.S. Environmental Protection Agency (2006) acute and chronic water-quality guidelines for the protection of aquatic organisms are shown for reference. Hardness-dependent guidelines (zinc, cadmium, and lead) were calculated assuming a water hardness of 100 milligrams per liter as calcium carbonate. 


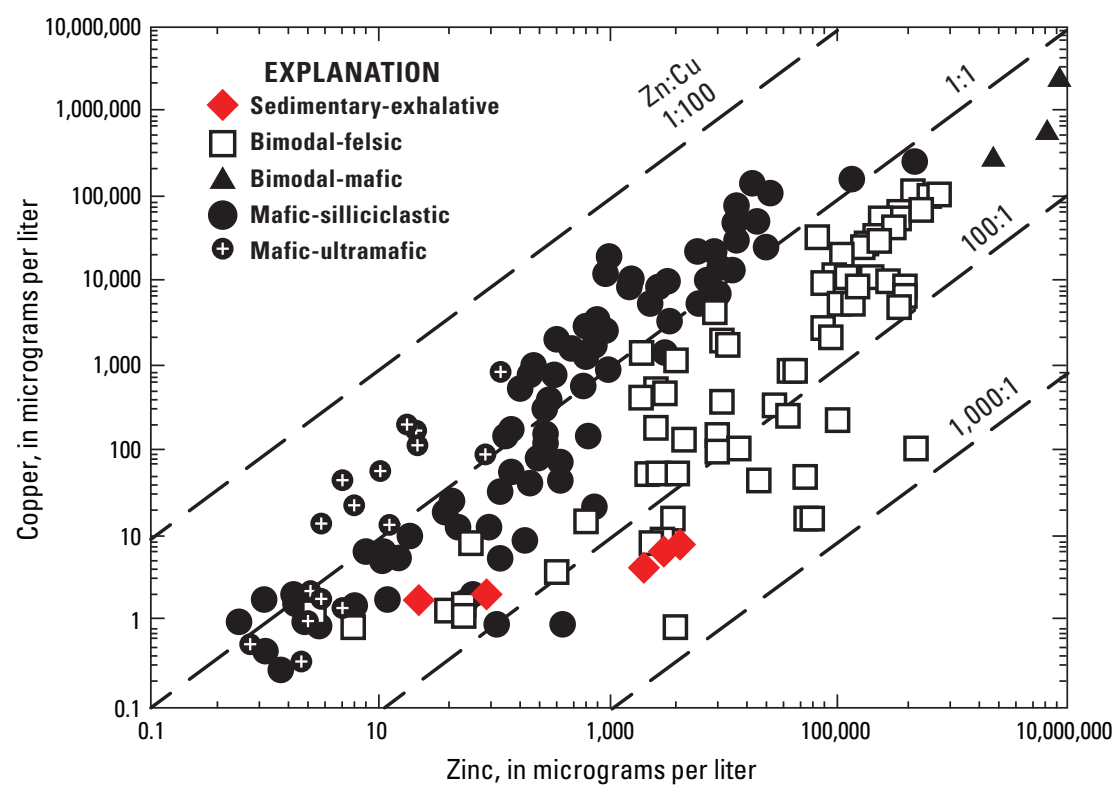

Figure 17. Geochemical data for dissolved copper (Cu) and zinc $(\mathrm{Zn})$ in drainage associated with sedex deposits. (Modified from Seal and Hammarstrom, 2003)

measure of the concentrations of dissolved $\mathrm{Ca}$ and $\mathrm{Mg}$ and is expressed in terms of an equivalent concentration of $\mathrm{CaCO}_{3}$, typically in milligrams per liter. The U.S. Environmental Protection Agency (2006) has presented hardness-dependent expressions for both acute (one-hour exposure) and chronic (four-day exposure) toxicity for $\mathrm{Cd}, \mathrm{Cr}, \mathrm{Cu}, \mathrm{Ni}, \mathrm{Pb}$, and $\mathrm{Zn}$ and limits independent of hardness for cyanide, $\mathrm{Al}, \mathrm{As}, \mathrm{Fe}, \mathrm{Hg}$, and Se (table 2).

Fugitive dust, which is windblown dust derived from mining operations or from trucks transporting ore concentrates, has been identified as an important issue associated with the Red Dog mine (Hasselbach and others, 2005; Kelley and Hudson, 2007). Detailed sampling of soils and moss along the $75-\mathrm{km}$ haul-road corridor from the Red Dog mine to the coast reveals elevated concentrations of $\mathrm{Cd}$ and $\mathrm{Pb}$. Concentrations are highest within $10 \mathrm{~m}$ of the haul road, but anomalous concentrations have been documented as far as $25 \mathrm{~km}$ away from the road (Hasselbach and others, 2005).

Atmospheric contamination can also occur because highly pyritic-pyrrhotitic orebodies that are exposed to oxidation by air circulating through open adits, manways, and exploration drill holes may evolve sulfur dioxide $\left(\mathrm{SO}_{2}\right)$ gas. In some cases, spontaneous combustion can cause sulfide ore to burn, as has been documented at the Sullivan mine (Brown and Miller, 1977; Good, 1977). Hot muck, the spontaneous combustion of high-sulfide ore in mine workings, is an environmental concern associated with processing ore from deposits with abundant pyrrhotite in the orebodies. The primary environmental concern is evolved $\mathrm{SO}_{2}$. Fires are ignited by the build-up of heat in stock piles caused by ore oxidation or may be triggered by blasting in areas of previously broken ore. Periodically, air emission can exceed $9.5 \mathrm{mg} / \mathrm{kg} \mathrm{SO}_{2}$ (Brown and Miller, 1977; Good, 1977), and $\mathrm{SO}_{2}$ release can acidify water in areas downwind from the release site. Because hot muck is easily avoided by using proper blasting techniques, it does not pose significant risks in modern mining operations.

\section{Human Health Issues}

Human-health effects of sedex deposits are generally associated with either the inhalation or the ingestion of metals. Metals can be ingested either through drinking water or as particulates. The U.S. Environmental Protection Agency (2009) has set primary maximum contaminant limits for $\mathrm{Al}, \mathrm{As}, \mathrm{Cd}, \mathrm{Cr}, \mathrm{Cu}$, $\mathrm{Fe}, \mathrm{Hg}, \mathrm{Mn}, \mathrm{Pb}, \mathrm{Se}$, and $\mathrm{Zn}$ for drinking water (table 2).

Risks are generally related to ingestion of $\mathrm{Pb}$-rich mine waste through incidental contact. Studies have demonstrated that the bioavailability of lead in the digestive tract varies according to mineralogy. Lead in galena $(\mathrm{PbS})$ and anglesite $\left(\mathrm{PbSO}_{4}\right)$ is considered to be less bioavailable than lead in cerussite $\left(\mathrm{PbCO}_{3}\right)$ (U.S. Environmental Protection Agency, 1999). In mine waste associated with sedex deposits, galena may weather to form either anglesite or cerussite. Anglesite is more likely to form in association with deposits with siliciclastic host rocks, whereas cerussite is more likely to form associated with carbonate-hosted deposits, such as Rampura-Agucha in Rajasthan, India, where galena in the gossan zone weathers to both anglesite and the more bioavailable cerussite (Shah, 2004).

Fugitive dust, as documented to be associated with the Red Dog mine, represents another medium for dispersing metals such as $\mathrm{Pb}, \mathrm{Zn}$, and $\mathrm{Cd}$ away from mining industrial areas. For all lead-bearing deposits, the fine grinding required for concentration by flotation increases the risk of inhalation because of the airborne transport of lead-bearing dust. This phenomenon is most likely to occur in semiarid to arid regions in which strong winds prevail. 
Table 2. Maximum environmental guidelines for contaminants relevant to mineral deposits.

[EPA, U.S. Environmental Protection Agency; WHO, World Health Organization; mg/kg, milligram per kilogram; $\mu \mathrm{g} / \mathrm{L}$, microgram per liter; -, not applicable]

\begin{tabular}{|c|c|c|c|c|c|c|}
\hline Element & \multicolumn{4}{|c|}{ Human health } & \multicolumn{2}{|c|}{ Aquatic ecosystem } \\
\hline Aluminum & 77,000 & 990,000 & 200 & - & 750 & 87 \\
\hline Arsenic & 23 & 160 & 10 & 10 & 340 & 150 \\
\hline Cadmium & 70 & 810 & 5 & 3 & $2 *$ & $0.25^{*}$ \\
\hline Copper & 3,100 & 41,000 & 1,300 & 2,000 & $13^{*}$ & $11^{*}$ \\
\hline Iron & 55,000 & 720,000 & 300 & - & - & 1,000 \\
\hline Mercury & 6.7 & 28 & 2 & 6 & 1.4 & 0.77 \\
\hline Manganese & 1,800 & 23,000 & 50 & 400 & - & - \\
\hline Molybdenum & 390 & 5,100 & - & 70 & - & - \\
\hline Nickel & 1,600 & 20,000 & - & 70 & $470^{*}$ & $52 *$ \\
\hline Lead & 400 & 800 & 15 & 10 & $65^{*}$ & $2.5^{*}$ \\
\hline Selenium & 390 & 5,100 & 50 & 10 & - & 5 \\
\hline Uranium & 230 & 3,100 & - & 15 & - & - \\
\hline Zinc & 23,000 & 310,000 & 5,000 & - & $120 *$ & $120 *$ \\
\hline
\end{tabular}

${ }^{1}$ Maximum contaminant levels; U.S. Environmental Protection Agency, 2009.

${ }^{2}$ Maximum contaminant levels; World Health Organization, 2008.

${ }^{3}$ Maximum and continuous concentrations; U.S. Environmental Protection Agency, 2006.

*Hardness-dependent water-quality standards (U.S. Environmental Protection Agency, 2006); value is based on a hardness of 100 milligrams per liter CaCO

In semiarid to arid areas, the human-health risks associated with $\mathrm{Hg}$ are more likely related to drinking-water supplies that are obtained from shallow groundwaters. At the $\mathrm{Zn}$-rich sedex deposits in arid Rajasthan, India, the common usage of shallow-dug wells as drinking-water sources in the vicinity of mines represents a potential, but unproven, human-health risk; the surficial weathering of mine wastes, particularly during the rainy season, may liberate metals to the local groundwater. In the case of sedex ores, the most likely metals of concern in drinking water are $\mathrm{Pb}, \mathrm{Zn}, \mathrm{Cd}$, $\mathrm{As}$, and $\mathrm{Tl}$, in addition to $\mathrm{Hg}$.

An additional human-health risk has been documented at the Sullivan mine, where four fatalities occurred in May 2006 in the vicinity of a waste-rock dump (Dawson and others, 2009). The deaths were due to oxygen deprivation in an enclosed shed used to monitor the discharge and chemistry of a toe drain at the base of a waste pile; the decreased oxygen concentrations were attributed to sulfide oxidation in the waste pile (Dawson and others, 2009; Hockley and others, 2009; Lahmira and others, 2009).

\section{Climate Effects on Geoenvironmental Signatures}

Climate plays a particularly important role in the potential environmental impact of mines that exploit sedex deposits. Its effect, however, is difficult to quantify systematically because insufficient data are available for a wide spectrum of climatic settings. Sedex deposits are located in diverse climatic settings, from tropical Australian settings (such as McArthur River [HYC] and Mount Isa), to temperate settings in North America (such as Balmat, N.Y.), to permafrost settings in northern Alaska and Canada (such as Red Dog) (Leach and others, 2005b). Nevertheless, temperature and humidity are the prime variables that control evaporation. Evaporation can be expected to limit the amount of water in semiarid to arid climates and can concentrate solutes in all climates. Acidity and total metal concentrations in mine drainage in arid environments are typically several orders of magnitude greater than those in temperate climates because of the concentrating effects of the evaporation of mine effluent and the resulting storage of metals and acidity in highly soluble metal-sulfate salt minerals. Minimal surface-water flow in these areas inhibits the generation of significant volumes of highly acidic, metal-enriched drainage. The concentrated release of stored contaminants to local watersheds may be initiated by precipitation following a dry spell. In wet climates, high water tables may reduce exposure of abandoned orebodies to oxidation and may continually flush existing tailings and mine dumps. Although metal-laden acidic mine water does form, it may be diluted to benign metal abundances within several hundred meters of the mine by mixing with a higher order stream.

Humidity-cell tests on mine tailings from the Red Dog mine provide some of the best insights into the role of climate on the behavior of sedex mine wastes. The humidity-cell tests were conducted at room temperature and under refrigerated conditions to assess the role of colder Alaskan climates on the weathering of mine wastes (Tetra Tech, 2009). The $\mathrm{pH}$ of the leachates from the room-temperature experiments reached a steady state of approximately $\mathrm{pH} 2$ after one year, whereas the refrigerated experiments reached a steady state of approximately $\mathrm{pH} 4$ after two years. Likewise, the steadystate concentration of sulfate in the leachates was approximately $1,000 \mathrm{mg} / \mathrm{L}$ for the room-temperature experiments and $100 \mathrm{mg} / \mathrm{L}$ for the refrigerated experiments. Thus, temperature has an important effect on the rate of weathering of sedex mine wastes. 


\section{Knowledge Gaps and Future Directions}

Ore genesis research during the past 40 years has fostered the preparation of robust descriptive and genetic models for sedex deposits. These studies have dramatically improved our understanding of fluid and metal sources, metaltransporting ligands, plumbing systems, and physical and chemical traps responsible for metal accumulation. Characteristics of sedex deposits outlined in this report identify those geologic criteria essential to deposit formation. Moreover, the deposit model described herein ranks these geologic criteria, using both empirical data and a genetic understanding of physicochemical, geologic, and mass balance parameters, to better evaluate the hydrothermal processes and sedimentary basin dynamics that control the number, size, and location of deposits within permissive tracts. While many sedex ore-formation processes are well understood, the synthesis presented here identifies several broad research topics listed below that, if addressed in meaningful ways, would further refine our understanding of sedex deposit genesis and enhance our ability to assess the unknown resource potential of diverse sedimentary basins.

- Direct study of sedex ore fluids has been limited. A few robust fluid inclusion microthermometry studies demonstrate that sedex deposits form as a consequence of warm saline brine circulation. New solute analyses of sedex fluid inclusions presented in this report define ore formation processes, sources of dissolved salt and water, and water/rock reactions that were critical to the geneses of these enormous ore-forming systems. However, as demonstrated by this model, new methods for quantifying fluid inclusion chemistry (that is, laser ablation inductively coupled plasma-mass spectrometry, raman, and ion chromatography) have the potential to provide new geochemical and massbalance constraints that would further revolutionize our understanding of sedex deposit genesis.

- One of the main findings of the synthesis is that sedex deposits, because of their enormous size, require geologic processes that operate at the basin scale. Integration of stratigraphic, biostratigraphic, sedimentologic, and structural architecture data for sedex deposit-hosting basins have been critical to determining the processes responsible for deposit genesis. Conducting similar multidisciplinary studies focused on understanding the interplay between basin dynamics and ore formation will augment and further refine this new model. For example, the new density-driven fluid-flow model described herein involves the apparent synchronicity between seawater evaporation on the basin platform, formation of MVT/Irish type deposits on basin margins, and deposition of sedex ores in deeper basin environments. Developing better stratigraphic control in ore-forming basins would corroborate observed correlations between ore formation and basinwide organic- rich metalliferous black shales and $\mathrm{PO}_{4}, \mathrm{Ba}, \mathrm{Fe}$, and Mn deposits, thus confirming the occurrence of these deposits as indicators of stratigraphic intervals with high mineral potential. Moreover, establishing better stratigraphic correlations would support regional geochemical zoning studies that might enhance our ability to vector towards deposits.

- The hydrologic processes that drove the hydrothermal systems responsible for sedex deposits are not well known. Sources of energy, heat transport and transfer processes, and geodynamic processes driving these basin-scale systems remain obscure. By integrating increasingly sophisticated numerical fluid-flow models, with constraints from fluid inclusion research, and robust stratigraphy and structural reconstructions, fluid-flow models ostensibly responsible for the formation of these deposits can be further evaluated and refined. Moreover, once these systems are better understood and integrated with appropriate numerical fluid-flow models, the accuracy of quantitative mineral assessments will increase significantly.

\section{References}

Abbott, J.G., Gordey, S.P., and Tempelman-Kluit, D.J., 1986, Setting of stratiform, sediment-hosted lead-zinc deposits in Yukon and northeastern British Columbia, in Morin, J.A., ed., Mineral deposits of northern Cordillera: Canadian Institute of Mining and Metallurgy Special Volume 37, p. 1-18.

Alpers, C.N., Blowes, D.W., Nordstrom, D.K., and Jambor, J.L., 1994, Secondary minerals and acid mine-water chemistry, in Jambor, J.L., and Blowes, D.W., eds., Short course handbook on environmental geochemistry of sulfide minewastes: Mineralogical Association of Canada, p. 247-270.

Alpers, C.N., and Nordstrom, D.K., 2000, Estimation of pre-mining conditions for trace metal conditions for trace metal mobility in mineralized areas-An overview, in International Conference on Acid Rock Drainage, 5th, Denver, Colo., May 21-24, 2000, Proceedings: Littleton, Colo., Society for Mining, Metallurgy, and Exploration, p. $463-472$.

Alpers, C.N., Nordstrom, D.K., Verosub, K.L., and Helm, C.M., 1999, Paleomagnetic reversal in Iron Mountain gossan provides limits on long-term premining metal flux rates: Geological Society of America Abstracts with Programs, v. 31, p. 33.

Ansdell, K.M., Nesbitt, B.E., and Longstaffe, F.J., 1989, A fluid inclusion and stable isotopic study of the Tom $\mathrm{Ba}-\mathrm{Pb}-$ Zn deposit, Yukon Territory, Canada: Economic Geology, v. 84, p. 841-856. 
Appold, M.S., and Garven, Grant, 2000, Reactive flow models of ore formation in the Southeast Missouri District: Economic Geology, v. 95, no. 8, p. 1605-1626.

Armstrong, P.A., 2005, Thermochronometers in sedimentary basins: Reviews in Mineralogy and Geochemistry, v. 58, p. 499-525.

Ayuso, R.A., Kelley, K.D., Leach, D.L., Young, L.E., Slack, J.F., Wandless, J.F., Lyon, A.M., and Dillingham, J.L., 2004, Origin of the Red Dog Zn-Pb-Ag deposits, Brooks Range, Alaska-Evidence from regional $\mathrm{Pb}$ and $\mathrm{Sr}$ isotope sources: Economic Geology, v. 99, no. 7, p. 1533-1553.

Badham, J.P.N., 1981, Shale-hosted Pb-Zn deposits—Products of exhalation of formation waters?: Applied Earth ScienceTransactions of the Institution of Mining and Metallurgy, Section B, v. 90, p. 70-76.

Bailes, R.J., Smee, B.W., Blackadar, D.W., and Gardner, H.D., 1986, Geology of the Jason lead-zinc-silver deposits, Macmillan Pass, eastern Yukon, in Morin, J.A., ed., Mineral Deposits of Northern Cordillera: Canadian Institute of Mining and Metallurgy Special Volume 37, p. 87-99.

Berner, R.A., and Raiswell, Robert, 1983, Burial of organic carbon and pyrite in sediments over Phanerozoic timeA new theory: Geochimica et Cosmochimica Acta, v. 47, p. $885-862$.

Bethke, C.M., 1985, A numerical model of compaction-driven groundwater flow and heat transfer and its application to the paleohydrology of intracratonic sedimentary basins: Journal of Geophysical Research, v. 90, p. 6817-6828.

Betts, P.G., Giles, D.L., and Lister, G.S., 2003, Tectonic environment of shale-hosted massive sulfide $\mathrm{Pb}-\mathrm{Zn}$ - $\mathrm{Ag}$ deposits of Proterozoic northeastern Australia: Economic Geology, v. 98, p. $557-576$.

Betts, P.G., Giles, D.L., and Lister, G.S., 2004, Aeromagnetic patterns of half-graben and basin inversion-Implications for sediment-hosted massive sulfide $\mathrm{Pb}-\mathrm{Zn}$ - $\mathrm{Ag}$ exploration: Journal of Structural Geology, v. 26, p. 1137-1156.

Betts, P.G., and Lister, G.S., 2001, A comparison of the "strike-slip" versus the "episodic rif sag" models for the origin of the Isa superbasin: Australian Journal of Earth Sciences, v. 48, p. 265-280.

Blowes, D.W., and Ptacek, C.J., 1994, Acid-neutralization mechanisms in inactive mine tailings, in Jambor, J.L., and Blowes, D.W., eds., Short course handbook on environmental geochemistry of sulfide mine-wastes: Mineralogical Association of Canada, p. 271-292.

Blowes, D.W., Ptacek, C.J., and Jurjovec, Jasna, 2003, Mill tailings-Hydrogeology and geochemistry, in Jambor, J.L., Blowes, D.W., and Ritchie, A.I.M., eds., Environmental aspects of mine wastes: Mineralogical Association of Canada Short Course Series, v. 31, p. 95-116.
Blowes, D.W., Reardon, E.J., Jambor, J.L., and Cherry, J.A., 1991, The formation and potential importance of cemented layers in inactive sulfide mine tailings: Geochimica et Cosmochimica Acta, v. 55, no. 4, p. 965-978.

Bradley, D.C., 2008, Passive margins through Earth history: Earth-Science Reviews v. 91, p. 1-36.

Bresser, H.A., 1992, Origin of base metal vein mineralization in the Lawn Hill mineral field, north western Queensland: Townsville, James Cook University, B.Sc. thesis, 115 p.

Briggs, P.H., Motooka, J.M., Bailey, E.A., Cieutat, B.A., Burner, S.A., Kelley, K.D., and Ficklin, W.H., 1992, Analytical results of soil, stream sediment, panned concentrate, and water samples from the Lik deposit, northwestern Brooks Range, Alaska: U.S. Geological Survey Open-File Report 92-15A (paper version) and 92-15B (diskette version).

Brock, J.S., 1973, Geophysical exploration leading to the discovery of the Faro deposit: Canadian Mining and Metallurgical Bulletin, v. 66, p. 97-116.

Brooks, W.E., 2012, Silver, in 2010 Minerals yearbook: U.S. Geologial Survey, p. 68.61-68.15.

Brown, R.L., and Miller, F.J.L., 1977, Pollution problems associated with Sullivan mine hot muck: Canadian Institute Mining and Metallurgy Bulletin, v. 70, no. 782, p. 89-92.

Brumsack, H.J., 2006, The trace metal content of recent organic carbon-rich sediments-Implications for Cretaceous black shale formation: Palaeogeography, Palaeoclimatology, Palaeoecology, v. 232, no. 2-4, p. 344-361.

Carne, R.C., and Cathro, R.J., 1982, Sedimentary exhalative (sedex) zinc-lead-silver deposits, northern Canadian Cordillera: CIM Bulletin, v. 75, no. 840, p. 66-78.

Carpenter, A.B., 1978, Origin and chemical evolution of brines sedimentary basins: Oklahoma Geological Survey Circular, v. 79 , p. $60-77$.

Cathles, L.M., and Adams, J.J., 2005, Fluid flow and petroleum and mineral resources in the upper $(<20-\mathrm{km})$ continental crust, in Hedenquist, J.W., Thompson, J.F.H., Goldfarb, R.J., and Richards, J.P., eds., Economic geology-One hundredth anniversary volume, 1905-2005: Littleton, Colo., Society of Economic Geologists, p. 77-110.

Clauser, Christoph, and Huenges, Ernst, 1995, Thermal conductivity of rocks and minerals, in Ahrens, T.J., ed., Rock physics and phase relations - A handbook of physical constants: Washington, D.C., American Geophysical Union, AGU Reference Shelf, v. 3, p. 105-126.

Cooke, D.R., Bull, S.W., Donovan, Serena, and Rogers, J.R., 1998, K-metasomatism and base metal depletion in volcanic rocks from the McArthur Basin, Northern TerritoryImplications for base metal mineralization: Economic Geology, v. 93, no. 8, p. 1237-1263. 
Cooke, D.R., Bull, S.W., Large, R.R., and McGoldrick, P.J., 2000, The importance of oxidized brines for the formation of Australian Proterozoic stratiform sediment-hosted $\mathrm{Pb}-\mathrm{Zn}$ (sedex) deposits: Economic Geology, v. 95, no. 1, p. 1-18.

Cox, R., and Curtis, R., 1977, The discovery of the Lady Loretta zinc-lead-silver deposit, northwest Queensland, Australia-A geochemical exploration case history: Journal of Geochemical Exploration, v. 8, p. 189-202.

Cravotta, C.A., II, 1994, Secondary iron-sulfate minerals as sources of sulfate and acidity - Geochemical evolution of acidic ground water at a reclaimed surface coal mine in Pennsylvania, in Alpers, C.N., and Blowes, D.W., eds., Environmental geochemistry of sulfide oxidation: American Chemical Society Symposium Series 550, p. 345-364.

Davidson, G.J., 1998, Alkali alteration styles and mechanisms, and their implications for a "brine factory" source of base metals in the rift-related McArthur Group, Australia: Australian Journal of Earth Sciences, v. 45, no. 1, p. 33-49.

Dawson, Bruce, Phillip, Mark, and O'Kane, Mike, 2009, Sullivan Mine fatalities incident-Site setting, acid rock drainage management, land reclamation and investigation into fatalities, in Proceedings of Securing the Future and Eighth International Conference on Acid Rock Drainage (ICARD), Skellefteå, Sweden, June 23-26, 2009: Stockholm, Sweden, Swedish Association of Mines, Minerals, and Metal Producers (SveMin), 10 p.

Deb, Mihir, and Thorpe, R.I., 2001, Geochronological constraints in the Precambrian geology of northwestern India and their metallogenic implications, in Deb, Mihir, and Goodfellow, W.D., eds., Sediment-hosted lead-zinc deposits: New Delhi, Narosa Publishing House, p. 246-263.

Duval, J.S., Carson, J.M., Holman, P.B., and Darnley, A.G., 2005, Terrestrial radioactivity and gamma-ray exposure in the United States and Canada: U.S. Geological Survey Open-File Report 2005-1413.

Einsele, G., 2000, Sedimentary basins_-Evolution, facies, and sediment budget: Berlin, Springer, $792 \mathrm{p}$.

Emsbo, Poul, 2000, Gold in sedex deposits: Reviews in Economic Geology, v. 13, p. 427-437.

Emsbo, Poul, 2002, Metallogeny of Phanerozoic intracratonic rift basins: Geological Society of America Abstracts with Programs, v. 34, no. 6, p. 13.

Emsbo, Poul, 2004, Genetic links among syngenetic metal accumulations in sedimentary basins - Giant sedimenthosted metal deposits to metalliferous black shales: Geological Soceity of America Abstracts with Programs, v. 36, no. 5, p. 199.
Emsbo, Poul, 2008, Metalliferous organic-rich black shalesAre exhalative hydrothermal processes fundamental to their genesis?, in International Geological Congress, 33d, Oslo, Norway, August 6-14, 2008, Abstracts CD-ROM: International Geological Congress.

Emsbo, Poul, 2009a, Fluid inclusion Cl-Br-Na ratios implicate residual evaporative brines in the formation of supergiant sedex zinc deposits: Geological Society of America Abstracts with Programs, v. 41, no. 7, p. 254.

Emsbo, Poul, 2009b, Geologic criteria for the assessment of sedimentary exhalative (sedex) $\mathrm{Zn}-\mathrm{Pb}-\mathrm{Ag}$ deposits: U.S. Geological Survey Open-File Report 2009-1209, $21 \mathrm{p}$.

Emsbo, Poul, Groves, D.I., Hofstra, A.H., and Bierlein, F.P., 2006, The giant Carlin gold province - A protracted interplay of orogenic, basinal, and hydrothermal processes above a lithospheric boundary: Mineralium Deposita, v. 41, no. 6, p. 517-525.

Emsbo, Poul, Hofstra, A.H., Johnson, C.A., Koenig, Alan, Grauch, Richard, Zhang Xing-chun, Hu, Rui-zhong, Su, Wen-chao, and Pi, Dao-hui, 2005, Lower Cambrian metallogenesis of south China-Interplay between diverse basinal hydrothermal fluids and marine chemistry, in Mao, Jingwen, and Bierlein, F.P., eds., Mineral deposit research-Meeting the global challenge. Proceedings of the Eighth Biennial SGA Meeting, Beijing, China, August 18-21, 2005: Heidelberg, Springer, p. 115-118.

Emsbo, Poul, Hutchinson, R.W., Hofstra, A.H., Volk, J.A., Bettles, K.H., Baschuk, G.J., and Johnson, C.A., 1999, Syngenetic Au on the Carlin trend-Implications for Carlintype deposits: Geology, v. 27, no. 1, p. 59-62.

Emsbo, Poul, and Johnson, C.A., 2004, Formation of modern and Paleozoic stratiform barite at cold methane seeps on continental margins-Comment: Geology, v. 32, p. e64.

Fallon, G.N., and Busuttil, Stephen, 1992, An appraisal of the geophysical effects of the Mount Isa ore bodies: Exploration Geophysics, v. 23, p. 133-140.

Feltrin, Leonardo, 2008, Predictive modelling of prospectivity for $\mathrm{Pb}-\mathrm{Zn}$ deposits in the Lawn Hill Region, Queensland, Australia: Ore Geology Reviews, v. 34, no. 3, p. 399-427.

Ford, K.L., Keating, Pierre, and Thomas, M.D., 2007, Overview of geophysical signatures associated with Canadian ore deposits, in Goodfellow, W.D., ed., Mineral deposits of Canada - A synthesis of major deposit-types, district metallogeny, the evolution of geological provinces, and exploration methods: Geological Survey of Canada, Mineral Deposits Division, Special Publication 5, p. 939-970.

Fuerstenau, M.C., Jameson, G.J., and Yoon, R.H., 2007, Froth flotation-A century of innovation: Littleton, Colo., Society for Mining, Metallurgy, and Exploration, 891 p. 
Gardner, H.D., and Hutcheon, Ian, 1985, Geochemistry, mineralogy, and geology of the Jason $\mathrm{Pb}-\mathrm{Zn}$ deposits, Macmillan pass, Yukon, Canada: Economic Geology, v. 80, p. 1257-1276.

Gartner Lee, 2006, Anvil Range Mine Complex 2005 annual environmental report-Water License QZ03-059: Gartner Lee Limited, accessed fall 2009 at http://www.faromine.ca/ reference/library.html.

Gartner Lee, 2007, Anvil Range Mine Complex 2006 annual environmental report-Water License QZ03-059: Gartner Lee Limited, accessed fall 2009 at http://www.faromine.ca/ reference/library.html.

Garven, Grant, Bull, S.W., and Large, R.R., 2001, Hydrothermal fluid flow models of stratiform ore genesis in the McArthur Basin, Northern Territory, Australia: Geofluids, v. 1 , no. 4, p. 289-311.

Garven, Grant, Raffensperger, J.P., Dumoulin, J.A., Bradley, D.C., Young, L.E., Kelley, K.D., and Leach, D.L., 2003, Coupled heat and fluid flow modeling of the Carboniferous Kuna Basin, Alaska-Implications for the genesis of the Red Dog Pb-Zn-Ag-Ba ore district: Journal of Geochemical Exploration, v. 78-79, no. 2003, p. 215-219.

Good, B.H., 1977, The oxidation of sulphide minerals in the Sullivan mine: Canadian Institute of Mining and Metallurgy Bulletin, v. 70, no. 782, p. 83-88.

Goodfellow, W.D., 1987, Anoxic stratified oceans as a source of sulphur in sediment-hosted stratiform $\mathrm{Zn}-\mathrm{Pb}$ deposits (Selwyn Basin, Yukon, Canada): Chemical Geology, v. 65, p. 359-382.

Goodfellow, W.D., 2004, Geology, genesis and exploration of SEDEX deposits, with emphasis on the Selwyn Basin, Canada: New Delhi, Narosa Publishing House, 24-99 p.

Goodfellow, W.D., 2007, Base metal metallogeny of the Selwyn Basin, Canada, in Goodfellow, W.D., ed., Mineral deposits of Canada - A synthesis of major deposit-types, district metallogeny, the evolution of geological provinces, and exploration methods: Geological Survey of Canada, Mineral Deposits Division, Special Publication 5, p. 553-579.

Goodfellow, W.D., and Jonasson, I.R., 1987, Environment of formation of the Howards Pass (XY) Zn-Pb deposit, Selwyn Basin, Yukon, in Morin, J.A., ed., Mineral deposits of Northern Cordillera: Montreal, Canadian Institute of Mining and Metallurgy, p. 19-50.

Goodfellow, W.D., and Lydon, J.W., 2007, Sedimentary exhalative (SEDEX) deposits, in Goodfellow, W.D., ed., Mineral deposits of Canada-A synthesis of major deposittypes, district metallogeny, the evolution of geological provinces, and exploration methods: Geological Survey of Canada, Mineral Deposits Division, Special Publication 5, p. $163-184$.
Goodfellow, W.D., Lydon, J.W., and Turner, R.J.W., 1993, Geology and genesis of stratiform sediment-hosted (SEDEX) zinc-lead-silver sulphide deposits, in Kirkham, R.V., Sinclair, W.D., Thorpe, R.I., and Duke, J.M., eds., Mineral deposit modeling: Geological Association of Canada special paper 40, p. 201-251.

Goodfellow, W.D., and Rhodes, D.D., 1991, Geological setting, geochemistry and origin of the Tom stratiform $\mathrm{Zn}$ $\mathrm{Pb}$-Ag-barite deposits, in Abbott, J.G., and Turner, R.J.W., eds., Mineral deposits of the northern Canadian Cordillera, Yukon, northeastern British Columbia (field trip 14): Calgary, Geological Survey of Canada, p. 177-244.

Graham, G.E., and Kelley, K.D., 2009, The Drenchwater deposit, Alaska-An example of a natural low $\mathrm{pH}$ environment resulting from weathering of an undisturbed shalehosted $\mathrm{Zn}-\mathrm{Pb}-\mathrm{Ag}$ deposit: Applied Geochemistry, v. 24, p. 232-245.

Gustafson, L.B., and Williams, Neil, 1981, Sediment-hosted stratiform deposits of copper, lead and zinc, in Skinner, B.J., ed., Economic Geology - Seventy-fifth anniversary volume, 1905-1980: El Paso, Tex., Economic Geology Publishing Company, p. 139-178.

Hammarstrom, J.M., Seal, R.R., II, Ouimette, A.P., and Foster, S.A., 2001, Sources of metals and acidity at the Elizabeth and Ely mines - Geochemistry and mineralogy of solid mine waste and the role of secondary minerals in metal recycling, in Hammarstrom, J.M., and Seal, R.R., II, eds., Environmental geochemistry and mining history of massive sulfide deposits in the Vermont copper belt: Society of Economic Geologists, Field Trip Guidebook Series, v. 35, pt. II, p. 213-248.

Hanor, J.S., 1994, Origin of saline fluids in sedimentary basins, in Parnell, John, ed., Geofluids - Origin, migration and evolution of fluids in sedimentary basins: London, Geological Society Special Publication 78, p. 151-174.

Hanor, J.S., 1996, Controls on the solubilization of lead and zinc in basinal brines, in Sangster, D.F, ed., Carbonatehosted lead-zinc deposits: Littleton, Colo., Society of Economic Geologists Special Publication 4, p. 483-500.

Hasselbach, L.M., Ver Hoef, J.M., Ford, J., Neitlich, P., Crecelius, E., Berryman, S., Wolk, B., and Bohle, T., 2005, Spatial patterns of cadmium and lead deposition on and adjacent to National Park Service lands in the vicinity of Red Dog Mine, Alaska: Science of the Total Environment, v. 348, p. 211-230.

Hawke, P.J., and Booker, P.I., 2001, Can sphalerite be a polarisable mineral? - An example from the Century $\mathrm{Zn}-\mathrm{Pb}$ deposit: ASEG Extended Abstracts, v. 2001, no. 1, 4 p. 
Hitzman, M.W., and Beaty, D.W., 1996, The Irish Zn-Pb-(Ba) orefield, in Sangster, D.F., ed., Carbonate-hosted lead-zinc deposits: Littleton, Colo., Society of Economic Geologists Special Publication 4, p. 112-143.

Hockley, Daryl, Kuit, Walter, and Phillip, Mark, 2009, Sullivan Mine fatalities incident-Key conclusions and implications for other sites, in Proceedings of Securing the Future and Eighth International Conference on Acid Rock Drainage (ICARD), Skellefteå, Sweden, June 23-26, 2009: Stockholm, Sweden, Swedish Association of Mines, Minerals, and Metal Producers (SveMin), 11 p.

Hofstra, A.H., and Emsbo, Poul, 2004, Solubility of metals and nutrients in brines - Implications for ore deposits, bioproductivity, and anoxia in sedimentary basins: Geological Society of America Abstracts with Programs, v. 36, no. 5, p. 199.

Hoover, D.B., Heran, W.D., and Hill, P.L., 1992, The geophysical expression of selected mineral deposit models: U.S. Geological Survey Open File Report 92-557, 129 p.

Hunt, J.M., 1996, Petroleum geochemistry and geology: New York, Freeman \& Company, 743 p.

Hutchinson, R.W., 1980, Massive base metal sulphide deposits as guides to tectonic evolution, in Strangway, D.W., ed., The continental crust and its mineral deposits: Geological Association of Canada special paper 20, p. 659-684.

Ireland, Tim, Large, R.R., McGoldrick, P.J., and Blake, Michael, 2004, Spatial distribution patterns of sulfur isotopes, nodular carbonate, and ore textures in the McArthur River (HYC) Zn-Pb-Ag Deposit, Northern Territory, Australia: Economic Geology, v. 99, no. 8, p. 1687-1709.

Jambor, J.L., 2003, Mine-waste mineralogy and mineralogical perspectives of acid-base accounting, in Jambor, J.L., Blowes, D.W., and Ritchie, A.I.M., eds., Environmental aspects of mine wastes: Mineralogical Association of Canada Short Course Series, v. 31, p. 117-146.

Jambor, J. L., Dutrizac, J. E., Groat, L. A., and Raudsepp, Mati, 2002, Static tests of neutralization potentials of silicate and aluminosilicate minerals: Environmental Geology, v. 43 , p. $1-17$.

Jennings, D.S., and Jilson, G.A., 1986, Geology and sulphide deposits of the Anvil Range, Yukon, in Morin, J.A., ed., Mineral deposits of northern Cordillera: Canadian Institute Mining and Metallurgy Special Volume 37, p. 339-361.

Johnson, C.A., Emsbo, Poul, Poole, F.G., and Rye, R.O., 2009, Sulfur and oxygen isotopes in sediment-hosted stratiform barite deposits: Geochimica et Cosmochimica Acta, v. 73, no. 1, p. 133-147.
Johnson, C.A., Kelley, K.D., and Leach, D.L., 2004, Sulfur and oxygen isotopes in barite deposits of the Western Brooks Range, Alaska, and implications for the origin of the Red Dog massive sulfide deposits: Economic Geology, v. 99 , no. 7 , p. 1435-1448.

Johnson, K.M., Doebrich, J.L., du Bray, E.A., and Foley, N.K., 2008, Mineral deposits research required for the next national mineral resource assessment - A collaborative opportunity: Geological Society of America Abstracts with Programs, v. 40, no. 1, p. 50.

Jones, G.D., Whitaker, F.F., Smart, P.L., and Sanford, W.E., 2002, Fate of reflux brines in carbonate platforms: Geology, v. 30, p. 371-374.

Jurjovec, Jasna, Ptacek, C.J., and Blowes, D.W., 2002, Acid neutralization mechanisms and metal release in mine tailings - A laboratory column experiment: Geochimica et Cosmochimica Acta, v. 66, no. 9, p. 1511-1523.

Kaufmann, Bernd, 2006, Calibrating the Devonian time scale-A synthesis of U-Pb ID-TIMS ages and conodont stratigaphy: Earth Science Review, v. 76, p. 175-190.

Kelley, K.D., Borden, J.C., Bailey, E.A., Fey, D.L., Motooka, J.M., and Roushey, B.H., 1992, Geochemically anomalous areas in the west-central part of the Howard Pass Quadrangle, National Petroleum Reserve, Brooks Range, AlaskaEvidence for sediment-hosted $\mathrm{Zn}-\mathrm{Pb}-\mathrm{Ag}-\mathrm{Ba}$ mineralization, in Evans, D.C., and Dusel-Bacon, Cynthia, eds., Geologic studies in Alaska by the U.S. Geological Survey, 1991: U.S. Geological Survey Bulletin 2041, p. 60-69.

Kelley, K.D., Dumoulin, J.A., and Jennings, Scott, 2004a, The Anarraaq $\mathrm{Zn}-\mathrm{Pb}-\mathrm{Ag}$ and barite deposit, Northern AlaskaEvidence for replacement of carbonate by barite and sulfides: Economic Geology, v. 99, no. 7, p. 1577-1591.

Kelley, K.D., and Hudson, Travis, 2007, Natural versus anthropogenic dispersion of metals to the environment in the Wulik River area, western Brooks Range, northern Alaska: Geochemistry-Exploration, Environment, Analysis, v. 7, p. 87-96.

Kelley, K.D., and Jennings, Scott, 2004, A special issue devoted to barite and $\mathrm{Zn}-\mathrm{Pb}$-Ag deposits in the Red Dog District, Western Brooks Range, Northern Alaska [preface]: Economic Geology, v. 99, no. 7, p. 1267-1280.

Kelley, K.D., and Kelley, D.L., 2003, Metal dispersion and mobility in soils from the Lik $\mathrm{Zn}-\mathrm{Pb}-\mathrm{Ag}$ massive sulphide deposit, NW Alaska-Environmental and exploration implications: Geochemistry-Exploration, Environment, Analysis, v. 3, p. 179-195. 
Kelley, K.D., Leach, D.L., Johnson, C.A., Clark, J.L., Fayek, Mostafa, Slack, J.F., Anderson, V.M., Ayuso, R.A., and Ridley, W.I., 2004b, Textural, compositional, and sulfur isotope variations of sulfide minerals in the Red Dog Zn-PbAg deposits, Brooks Range, Alaska-Implications for ore formation: Economic Geology, v. 99, no. 7, p. 1509-1532.

Kelley, K.D., Seal, R.R., Schmidt, J.M., Hoover, D.B., and Klein, D.P., 1995, Sedimentary exhalative Zn-Pb-Ag deposits, chapter 29 of du Bray, E.A., ed., Preliminary compilation of descriptive geoenvironmental mineral deposit models: U.S. Geological Survey Open-File Report 95-0831, p. $225-233$.

Kelley, K.D., and Taylor, C.D., 1997, Environmental geochemistry of shale-hosted Ag- $\mathrm{Pb}-\mathrm{Zn}$ massive sulfide deposits in northwest Alaska-Natural background concentrations of metals in water from mineralized areas: Applied Geochemistry, v. 12, p. 397-409.

Kharaka, Y.K., Maest, A.S., Carothers, W.W., Law, L.M., Lamothe, P.J., and Fries, T.L., 1987, Geochemistry of metal-rich brines from central Mississippi Salt Dome basin, U.S.A: Applied Geochemistry, v. 4, p. 543-561.

Kreuzer, O.P., Etheridge, M.A., Guj, Pietro, McMahon, M.E., and Holden, D.J., 2008, Linking mineral deposit models to quantitative risk analysis and decision-making in exploration: Economic Geology, v. 103, no. 4, p. 829-850.

Lahmira, Belkacem; Lefebvre, René; Hockley, Daryl; and Phillip, Mark, 2009, Sullivan Mine fatalities incidentNumerical modeling of gas transport and reversal in gas flow directions, in Proceedings of Securing the Future and Eighth International Conference on Acid Rock Drainage (ICARD), Skellefteå, Sweden, June 23-26, 2009: Stockholm, Sweden, Swedish Association of Mines, Minerals, and Metal Producers (SveMin), 10 p.

Large, D., and Walcher, E., 1999, The Rammelsberg massive sulphide $\mathrm{Cu}-\mathrm{Zn}-\mathrm{Pb}$-Ba-Deposit, Germany-An example of sediment-hosted, massive sulphide mineralisation: Mineralium Deposita, v. 34, p. 522-538.

Large, D.E., 1980, Geological parameters associated with sediment-hosted, submarine exhalative $\mathrm{Pb}-\mathrm{Zn}$ depositsAn empirical model for mineral exploration: Geologisches Jahrbuch, v. D40, p. 59-129.

Large, D.E., 1983, Sediment-hosted massive sulphide leadzinc deposits-An empirical model, in Sangster, D.F., ed., Sediment-hosted stratiform lead-zinc deposits: Mineralogical Association of Canada Short Course Handbook, v. 9, p. 1-29.
Large, R.R., Bodon, S., Davidson, G., and Cooke, D.R., 1996a, The chemistry of BHT ore formation-One of the keys to understanding the differences between SEDEX and BHT deposits, in Pongratz, June, and Davidson, G.J., eds., New developments in Broken Hill type deposits: Centre for Ore Deposit and Exploration Studies (CODES) Special Publication 1, p. 105-111.

Large, R.R., Bull, S.W., Selley, David, Yang, J., Cooke, D.R., Garven, Grant, and McGoldrick, P.J., 2002, Controls on the formation of giant stratiform sediment-hosted $\mathrm{Zn}-\mathrm{Pb}-\mathrm{Ag}$ deposits - With particular reference to the North Australian Proterozoic, in Cooke, D.R., and Pongrantz, June, eds., Giant ore deposits-Characteristics, genesis and exploration: Centre for Ore Deposit and Exploration Studies (CODES) Special Publication 4, p. 107-149.

Large, R.R., Bull, S.W., Cooke, D.R., and McGoldrick, P.J., 1996b, Review of genetic models at HYC — Constraints from new sedimentology, alteration halo studies and fluid chemical modelling: Contributions of the Economic Geology Research Unit, v. 55, p. 72-74.

Large, R.R., Bull, S.W., Cooke, D.R., and McGoldrick, P.J., 1998, A genetic model for the H.Y.C. Deposit, AustraliaBased on regional sedimentology, geochemistry, and sulfide-sediment relationships: Economic Geology, v. 93, no. 8, p. 1345-1368.

Large, R.R., Bull, S.W., McGoldrick, P.J., Walters, Steve, Derrick, G.M., and Carr, G.R., 2005, Stratiform and stratabound $\mathrm{Zn}-\mathrm{Pb}-\mathrm{Ag}$ deposits in Proterozoic sedimentary basins, northern Australia, in Hedenquist, J.W., Thompson, J.F.H., Goldfarb, R.J., and Richards, J.P., eds., Economic geologyOne hundredth anniversary volume, 1905-2005: Littleton, Colo., Society of Economic Geologists, 931-963 p.

Large, R.R., and McGoldrick, P.J., 1998, Lithogeochemical halos and geochemical vectors to stratiform sediment hosted Zn-Pb-Ag deposits, 1-Lady Loretta Deposit, Queensland: Journal of Geochemical Exploration, v. 63, no. 1, p. 37-56.

Large, R.R., McPhie, Jocelyn, Gemmell, J.B., Herrmann, Walter, and Davidson, G.J., 2001, The spectrum of ore deposit types, volcanic environments, alteration halos, and related exploration vectors in submarine volcanic successions-Some examples from Australia: Economic Geology, v. 96 , no. 5, p. 913-938.

Le Tran, K.J., 1972, Geochemical study of hydrogen sulfide adsorbed in sediments, in von Gaertner, H.R., and Wehner, Hermann, eds., Advances in organic geochemistry: Oxford, Pergamon Press, p. 717-726. 
Leach, D., Marsh, E., Bradley, D., Gardoll, S., and Huston, D., 2005a, The distribution of SEDEX Pb-Zn deposits through Earth history, in Mao, Jingwen, and Bierlein, F.P., eds., Mineral deposit research-Meeting the global challenge. Proceedings of the Eighth Biennial SGA Meeting, Beijing, China, August 18-21, 2005: Heidelberg, Springer, p. $145-148$.

Leach, D.L., Marsh, Erin, Emsbo, Poul, Rombach, C.S., Kelley, K.D., and Anthony, Mike, 2004, Nature of hydrothermal fluids at the shale-hosted Red Dog $\mathrm{Zn}-\mathrm{Pb}-\mathrm{Ag}$ deposits, Brooks Range, Alaska: Economic Geology, v. 99, no. 7, p. 1449-1480.

Leach, D.L., Sangster, D.F., Kelley, K.D., Large, R.R., Garven, Grant, Allen, C.R., Gutzmer, Jens, and Walters, S., 2005b, Sediment-hosted lead-zinc deposits-A global perspective, in Hedenquist, J.W., Thompson, J.F.H., Goldfarb, R.J., and Richards, J.P., eds., Economic geology—One hundredth anniversary volume, 1905-2005: Littleton, Colo., Society of Economic Geologists, p. 561-607.

Leventhal, J.S., 1983, An interpretation of carbon and sulfur relationships in Black Sea sediments as indicators of environments of deposition: Geochimica et Cosmochimica Acta, v. 47 , p. $133-137$.

Lin, Guichang, Nunn, J.A., and Deming, David, 2000, Thermal buffering of sedimentary basins by basement rocksImplications arising from numerical simulations: Petroleum Geoscience, v. 6, p. 299-307.

Lowe, C., Brown, D.A., Best, M.E., and Shives, R.B.K., 2001, High resolution geophysical survey of the Purcell Basin and Sullivan Deposit-Implications for bedrock geology and mineral exploration, in Lydon, J.W., Hoy, Trygve, Slack, J.F., and Knapp, M.E., eds., The geological environment of the Sullivan Deposit, British Columbia: Geological Association of Canada, Mineral Deposits Division, Special Publication 1, p. 355-369.

Lydon, J.W., 1983, Chemical parameters controlling the origin and deposition of sediment-hosted stratiform lead-zinc deposits, in Sangster, D.F, ed., Sediment-hosted stratiform lead-zinc deposits: Mineralogical Association of Canada Short Course Handbook, v. 9, p. 175-250.

Lydon, J.W., 1986, Models for the generation of metalliferous hydrothermal systems within sedimentary rocks, and their applicability to the Irish Carboniferous $\mathrm{Zn}-\mathrm{Pb}$ deposits, in Andrew, C.J., Crowe, R.W.A., Finlay, Sean, Pennell, W.M., and Pyne, J.F., eds., Geology and genesis of mineral deposits in Ireland: Dublin, Irish Association for Economic Geology, p. 555-577.

Lydon, J.W., 1995, Sedimentary exhalative sulphides (SEDEX), in Eckstrand, O.R., Sinclair, W.D., and Thorpe, R.I., eds., Geology of Canadian mineral deposit types: Geological Survey of Canada, Geology of Canada Series no. 8, p. 130-152.
Lydon, J.W., 1996, Characteristics of volcanogenic massive sulphide deposits - Interpretations in terms of hydrothermal convection systems and magmatic hydrothermal systems: Boletin Geologico y Minero, v. 107, no. 3-4, p. 215-264.

Lydon, J.W., 1997, Sedex deposits and global evolution: Geological Society of America Abstracts with Programs, v. 29 , no. 6 , p. $17-18$.

Lydon, J.W., 2004a, Genetic models for Sullivan and other SEDEX deposits, in Deb, M., and Goodfellow, W.D., eds., Sediment-hosted lead-zinc sulphide deposits-Attributes and models of some major deposits in India, Australia and Canada: New Delhi, Narosa Publishing House, p. 149-190.

Lydon, J.W., 2004b, Geology of the Belt-Purcell Basin and Sullivan Deposit, in Deb, M., and Goodfellow, W.D., eds., Sediment-hosted lead-zinc sulphide deposits-Attributes and models of some major deposits in India, Australia and Canada: New Delhi, Narosa Publishing House, p. 100-148.

Lydon, J.W., Jonasson, I.R., and Hudson, K.A., 1985, The distribution of gold in the TEA barite deposit, Yukon Territory, in Current research, part A: Geological Survey of Canada, Paper no. 85-1A, p. 661-667.

Lydon, J.W., Lancaster, R.D., and Karkkainen, P., 1979, Genetic controls of Selwyn Basin stratiform barite/sphalerite/galena deposits-An investigation of the dominant barium mineralogy of the Tea Deposit, Yukon, in Current research, part B: Geological Survey of Canada, Paper no. 79-1B, p. 223-229.

Lyons, T.W., Gellatly, A.M., McGoldrick, P.J., and Kah, L.C., 2006, Proterozoic sedimentary exhalative (SEDEX) deposits and links to evolving global ocean chemistry, in Kesler, S.E., and Ohmoto, Hiroshi, eds., Evolution of early Earth's atmosphere, hydrosphere, and biosphere-Constraints from ore deposits: Geological Society of America Memoirs, v. 198, p. 169-184.

Marqués, M., Martínez-Conde, E., Rovira, J., and Ordóñez, S., 2001, Heavy metals pollution of aquatic ecosystems in the vicinity of a recently closed underground lead-zinc mine (Basque Country, Spain): Environmental Geology, v. 40, p. 1125-1137.

McClay, K.R., and Bidwell, G.E., 1986, Geology of the Tom deposit, MacMillan Pass, Yukon, in Morin, J.A., ed., Mineral deposits of northern Cordillera: Canadian Institute of Mining and Metallurgy Special Volume 37, p. 100-114.

Menzie, W.D., and Mosier, D.L., 1986, Grade and tonnage model of sedimentary exhalative $\mathrm{Zn}-\mathrm{Pb}$, in Cox, D.P., and Singer, D.A., eds., Mineral deposit models: U.S. Geological Survey Bulletin 1693, p. 212-215.

Meyer, M.P., and Kurtak, J.M., 1992, Results of the 1991 U.S. Bureau of Mines Colville Mining District study: U.S. Bureau of Mines Open-File Report 75-92, 101 p. 
Moldovanyi, E.P., and Walter, L.M., 1992, Regional trends in water chemistry, Smackover Formation, Southwest Arkansas - Geochemical and physical controls: American Association of Petroleum Geologists Bulletin, v. 76, p. 864-894.

Moore, C.H., 1989, Carbonate diagenesis and porosity: New York, Elsevier, Developments in Sedimentology series, v. 46,338 p.

Murphy, F.C., Cull, J., Lee, T.J., Lee, S.K., and Song, Y., 2008, Magnetotelluric soundings and crustal architecture at Century mine, northern Australia: Australian Journal of Earth Sciences, v. 55, p. 655-667.

Mutton, A.J., 1997, The application of geophysics during evaluation of the Century Zinc Deposit, in Gubins, A.G., ed., Geophysics and geochemistry at the milleniumProceedings of Exploration 97, Fourth Decennial International Conference on Mineral Exploration: Toronto, Prospectors and Developers Association of Canada, p. 599-614.

Nelson, J.L.; Paradis, Suzanne; Christensen, John; and Gabites, Janet, 2002, Canadian Cordilleran Mississippi Valley-type deposits - A case for Devonian-Mississippian back-arc hydrothermal origin: Economic Geology, v. 97, no. 5, p. 1013-1036.

Neuzil, C.E., 1995, Abnormal pressures as hydrodynamic phenomena: American Journal of Sciences, v. 295, p. 742-786.

Nordstrom, D.K., and Alpers, C.N., 1999, Geochemistry of acid mine waters, in Plumlee, G.S., and Logsdon, M.J., eds., The environmental geochemistry of mineral deposits, part A-Processes, techniques, and health issues: Reviews in Economic Geology, v. 6A, p. 161-182.

O’Kane, M., and Ryland, L., 1999, Field performance monitoring of the Kimberly Operations siliceous tailings test plots, in Tailings and Mine Waste '99, Proceedings of the Sixth International Conference, Fort Collins, Colo., January 24-27, 1999: Rotterdam, A.A. Balkema, p. 23-33.

Paradis, Suzanne, and Nelson, J.L., 2007, Metallogeny of the Robb Lake carbonate-hosted zinc-lead district, northeastern British Columbia, in Goodfellow, W.D., ed., Mineral deposits of Canada - A synthesis of major deposit-types, district metallogeny, the evolution of geological provinces, and exploration methods: Geological Association of Canada, Mineral Deposits Division, Special Publication 5, p. 633-654.

Paradis, Suzanne, Nelson, J.L., and Irwin, S.E.B., 1998, Age constraints on the Devonian shale-hosted $\mathrm{Zn}-\mathrm{Pb}$-Ba deposits, Gataga district, northeastern British Columbia, Canada: Economic Geology, v. 93, p. 184-200.
Pigage, L.C., 1986, Geology of the Cirque barite-zinc-leadsilver deposits, northeastern British Columbia, Canada, in Morin, J.A., ed., Mineral deposits of northern Cordillera: Canadian Institute of Mining and Metallurgy Special Volume 37, p. 71-86.

Plumlee, G.S., 1999, The environmental geology of mineral deposits, in Plumlee, G.S., and Logsdon, M.J., eds., The environmental geochemistry of mineral deposits, part AProcesses, techniques, and health issues: Reviews in Economic Geology, v. 6A, p. 71-116.

Plumlee, G.S., Smith, K.S., Montour, M.R., Ficklin, W.H., and Mosier, E.L., 1999, Geologic controls on the composition of natural waters and mine waters draining diverse mineraldeposit types, in Filipek, L.H., and Plumlee, G.S., eds., The environmental geochemistry of mineral deposits, part B-Case studies and research topics: Reviews in Economic Geology, v. 6B, p. 373-432.

Polito, P.A., Kyser, T.K., Golding, S.D., and Southgate, P.N., 2006, Zinc deposits and related mineralization of the Burketown mineral field, including the world-class Century Deposit, Northern Australia_-Fluid inclusion and stable isotope evidence for basin fluid sources: Economic Geology, v. 101, no. 6, p. 1251-1273.

Raffensperger, J.P., and Vlassopoulos, Dimitri, 1999, The potential for free and mixed convection in sedimentary basins: Hyrdogeology Journal, v. 7, p. 505-520.

Rittenhouse, Gordon, 1967, Bromide in oilfield waters and its use in determining possibilities of origins its waters: American Association of Petroleum Geologists Bulletin, v. 51, p. 2430-2440.

Rollkotter, Jurgen, 2006, Organic matter-The driving force for early diagenesis, in Schulz, H.D., and Zabel, Matthias, eds., Marine geochemistry: New York, Springer, p. 125-166.

Runnells, D.D., Dupon, D.P., Jones, R.L., and Cline, D.J., 1998, Determination of natural background concentrations of dissolved components in water at mining, milling, and smelting sites: Mining Engineering, v. 50, no. 2, p. 65-71.

Runnells, D.D., Shepherd, T.A., and Angino, E.E., 1992, Metals in water-Determining natural background concentrations in mineralized areas: Environmental Science \& Technology, v. 26, p. 2316-2323.

Russell, M.J., Solomon, Michael, and Walshe, J.L., 1981, The genesis of sediment hosted exhalative zinc-lead deposits: Mineralium Deposita, v. 16, p. 113-127.

Sangster, D.F., 1968, Relative sulphur isotope abundances of ancient seas and stratabound sulphide deposits: Proceedings of the Geological Association of Canada, v. 19, p. 79-91. 
Sangster, D.F., 1990, Mississippi Valley-type and sedex leadzinc deposits-A comparative examination: Applied Earth Science-Transactions of the Institution of Mining and Metallurgy, Section B, v. 99, p. 21-42.

Sangster, D.F., 2002, The role of dense brines in the formation of vent-distal sedimentary-exhalative (SEDEX) lead-zinc deposits-Field and laboratory evidence: Mineralium Deposita, v. 37, no. 2, p. 149-157.

Sangster, D.F., and Hillary, E.M., 2000, SEDEX lead-zinc deposits-Proposed subtypes and their characteristics: Exploration and Mining Geology, v. 7, p. 341-357.

Sawkins, F.J., 1984, Ore genesis by episodic dewatering of sedimentary basins-Application to giant Proterozoic leadzinc deposits: Geology, v. 12, p. 451-454.

Schwartz, M.O., 1997, Mercury in zinc deposits-Economic geology of a polluting element: International Geology Review, v. 39, p. 905-923.

Seal, R.R., II, 2004, Geoenvironmental models for massive sulphide deposits with a emphasis on sedimentary leadzinc deposits, in Deb, Mihir, and Goodfellow, W.D., eds., Sediment-hosted lead-zinc sulphide deposits: New Delhi, Narosa Publishing House, p. 191-221.

Seal, R.R., II, and Hammarstrom, J.M., 2003, Geoenvironmental models of mineral deposits-Examples from massive sulfide and gold deposits, in Jambor, J.L., Blowes, D.W., and Ritchie, A.I.M., eds., Environmental aspects of mine wastes: Mineralogical Association of Canada Short Course Series, v. 31, p. 11-50.

Seal, R.R., II, Hammarstrom, J.M., and Meier, A.L., 2001a, Geochemical controls on drainage from massive sulfide mines in the eastern USA, in Cidu, Rosa, ed., Proceedings of the Tenth International Symposium on Water-Rock Interaction, Villasimius, Italy, July 10-15, 2001: Rotterdam, A.A. Balkema, p. 1273-1276.

Seal, R.R., II, Kornfeld, J.M., Meier, A.L., and Hammarstrom, J.M., 2001b, Geochemical settings of mine drainage in the Vermont copper belt, in Hammarstrom, J.M., and Seal, R.R., II, eds., Environmental geochemistry and mining history of massive sulfide deposits in the Vermont copper belt: Society of Economic Geologists, Field Trip Guidebook Series, v. 35, pt. II, p. 255-276.

Seal, R.R., II, Piatak, N.M., Levitan, D.M., Hageman, P.L., and Hammarstrom, J.M., 2009, Comparison of geochemical characteristics of modern-style mine wastes from a variety of mineral deposit types for insights into environmental challenges associated with future mining, in Proceedings of Securing the Future and Eighth International Conference on Acid Rock Drainage (ICARD), Skellefteå, Sweden, June 23-26, 2009: Stockholm, Sweden, Swedish Association of Mines, Minerals, and Metal Producers (SveMin), $10 \mathrm{p}$.
Shah, Nalin, 2004, Rampura-Agucha, a remobilized sedex deposit, southeastern Rajastahn, India, in Deb, Mihir, and Goodfellow, W.D., ed., Sediment-hosted lead-zinc sulphide deposits: New Delhi, Narosa Publishing House, p. 290-303.

Sims, P.K., O’Neill, J.M., Bankey, Viki, and Anderson, Eric, 2004, Precambrian basement geologic map of Montana-An interpretation of aeromagnetic anomalies: U.S. Geological Survey Scientific Investigations Map 2884, scale 1:1,000,000.

Singer, P.C., and Stumm, W.W., 1970, Acidic mine drainageThe rate-determining step: Science of the Total Environment, v. 167, no. 3921, p. 1121-1123.

Slack, J.F., 2008, Geochemistry of Paleozoic sedimentary rocks-Metallogenic significance, in Kelley, K.D., ed., Regional fluid flow and basin modeling in northern Alaska: U.S. Geological Survey Circular 1319, p. 6-9.

Slack, J.F., Kelley, K.D., Anderson, V.M., Clark, J.L., and Ayuso, R.A., 2004, Multistage hydrothermal silicification and Fe-Tl-As-Sb-Ge-REE enrichment in the Red Dog Zn$\mathrm{Pb}-\mathrm{Ag}$ district, northern Alaska - Geochemistry, origin, and exploration applications: Economic Geology, v. 99, no. 7, p. 1481-1508.

Sobek, A.A., Schuller, W.A., Freeman, J.R., and Smith, R.M., 1978, Field and laboratory methods applicable to overburdens and minesoils: U.S. Environmental Protection Agency Protection Technology EPA-600/2-78-054, 203 p.

Southgate, P.N., Kyser, T.K., Scott, D.L., Large, R.R., Golding, S.D., and Polito, P.A., 2006, A basin system and fluid-flow analysis of the $\mathrm{Zn}$ - $\mathrm{Pb}$-Ag Mount Isa-type deposits of northern Australia-Identifying metal source, basinal brine reservoirs, times of fluid expulsion, and organic matter reactions: Economic Geology, v. 101, no. 6, p. 1103-1115.

Stalder, Marcel, and Rozendaal, Abraham, 2004, Apatite nodules as an indicator of depositional environment and ore genesis for the Mesoproterozoic broken hill-type Gamsberg $\mathrm{Zn}-\mathrm{Pb}$ deposit, Namaqua Province, South Africa: Mineralium Deposita, v. 39, no. 2, p. 189-203.

Taylor, G.F., and Scott, K.M., 1982, Evaluation of gossans in relation to lead-zinc mineralization in the Mt. Isa inlier, Queensland: Journal of Australian, Geology and Geophysics, v. 7, p. 159-180.

Taylor, R.D., Leach, D.L., Bradley, D.C., and Pisarevsky, S.A., 2009, Compilation of mineral resource data for Mississippi Valley-type and clastic-dominated sediment-hosted lead-zinc deposits: U.S. Geological Survey Open-File Report 2009-1297, p. 42. Taylor, G.F., and Scott, K.M., 1982, Evaluation of gossans in relation to lead-zinc mineralization in the Mt. Isa inlier, Queensland: Journal of Australian, Geology and Geophysics, v. 7, p. 159-180. 
Teck Cominco Ltd., 2007, Environmental information document for the Aqqaluk extension, Sections 2.1 and 2.2: Vancouver, Teck Cominco Ltd., 46 p.

Tetra Tech, 2009, Red Dog Mine extension-Aqqaluk project. Final supplemental environmental impact statement, v. 1: U.S. Environmental Protection Agency, 530 p., accessed March 11, 2016, at http://dnr.alaska.gov/mlw/mining/ largemine/reddog/pdf/rdseis2009voll.pdf.

Theobald, P.K., Barton, H.N., Billings, T.M., Frisken, J.G., Turner, R.L., and VanTrump, George, Jr., 1978, Geochemical distribution of elements in stream sediment and heavy-mineral concentrate samples in the southern half of the National Petroleum Reserve, Alaska: U.S. Geological Survey Open-File Report 78-517, scale 1:500,000.

Tikkanen, G.D., 1986, World resources and supply of lead and zinc, in Bush, W.R., ed., Economics of internationally traded minerals: Society of Mining Engineers, Inc., p. 242-250.

Turcotte, D.L., and Schubert, Gerald, 1982, Geodynamics: New York, John Wiley and Sons, $450 \mathrm{p}$.

Turner, R.J.W., 1992, Formation of Phanerozoic stratiform sediment-hosted zinc-lead deposits - Evidence for the critical role of ocean anoxia: Chemical Geology, v. 99, p. $165-188$.

U.S. Environmental Protection Agency, 1999, IEUBK model bioavailability variable: U.S. Environmental Protection Agency EPA 540-F-00-006, accessed July 9, 2009, at http://www.epa.gov/superfund/lead/products/sspbbioc.pdf.

U.S. Environmental Protection Agency, [2006], National recommended water quality criteria: U.S. Environmental Protection Agency, accessed July 9, 2009, at http://www.epa.gov/waterscience/criteria/nrwqc-2006.pdf.

U.S. Environmental Protection Agency, 2009, National primary drinking water regulations: U.S. Environmental Protection Agency EPA 816-F-09-004, accessed July 9, 2009, at http://www.epa.gov/safewater/consumer/pdf/mcl.pdf.

Walter, L.M., Stuebler, A.M., and Huston, T.J., 1990, Br-Cl$\mathrm{Na}$ systematics in Illinois basin fluids - Constraints on fluid origin and evolution: Geology, v. 18, p. 315-318.

Warren, J.K., 2006, Evaporites-Sediments, resources, and hydrocarbons: New York, Springer, 1035 p.

Werner, Wolfgan, 1989, Contribution to the genesis of the SEDEX-type mineralizations of the Rhenish Massif (Germany) - Implications for future $\mathrm{Pb}-\mathrm{Zn}$ exploration: International Journal of Earth Sciences, v. 78, no. 2, p. 571-598.
White, W.W., III, Lapakko, K.A., and Cox, R.L., 1999, Statictest methods most commonly used to predict acid-mine drainage: Practical guidelines for use and interpretation, in Plumlee, G.S., and Logsdon, M.J., eds., The environmental geochemistry of mineral deposits, part A-Processes, techniques, and health issues: Reviews in Economic Geology, v. 6 A, p. $325-338$.

Wilkinson, J.J., Eyre, S.L., and Boyce, A.J., 2005, Oreforming processes in Irish-type carbonate-hosted $\mathrm{Zn}-\mathrm{Pb}$ deposits - Evidence from mineralogy, chemistry, and isotopic composition of sulfides at the Lisheen Mine: Economic Geology, v. 100, no. 1, p. 63-86.

Williams, Brian, and Brown, Colin, 1986, A model for the genesis of $\mathrm{Zn}-\mathrm{Pb}$ deposits in Ireland, in Andrew, C.J., Crowe, R.W.A., Finlay, S., Pennell, W.M., and Pyne, J.F., eds., Geology and genesis of mineral deposits in Ireland: Dublin, Irish Association for Economic Geology, p. 579-590.

Williamson, M.A., Kirby, C.S., and Rimstidt, J.D., 2006, Iron dynamics in acid mine drainage, in Barnhisel, R.I., ed., Seventh International Conference on Acid Rock Drainage, St. Louis, Mo., March 26-30, 2006, Proceedings: American Society of Mining and Reclamation, p. 2411-2423.

World Health Organization, 2008, Guidelines for drinkingwater quality ( $3 \mathrm{~d}$ ed.): Geneva, Switzerland, World Health Organization Press, accessed November 16, 2009, at http:// www.who.int/water_sanitation_health/dwq/gdwq3rev/en/.

Wynn, J.C., Kleinkopf, M.D., and Harrison, J.E., 1977, Audiofrequency magnetotelluric and gravity traverse across the crest of the Purcell anticlinorium, northwestern Montana: Geology, v. 5, no. 5, p. 309-312.

Yang, Jianwen, Bull, Stewart, and Large, R.R., 2004, Numerical investigation of salinity in controlling ore-forming fluid transport in sedimentary basins-Example of the HYC Deposit, northern Australia: Mineralium Deposita, v. 39, no. 5-6, p. 622-631.

Yang, Jianwen, Large, R.R., Bull, Stewart, and Scott, D.L., 2006, Basin-scale numerical modeling to test the role of buoyancy-driven fluid flow and heat transfer in the formation of stratiform $\mathrm{Zn}-\mathrm{Pb}-\mathrm{Ag}$ deposits in the Northern Mount Isa Basin: Economic Geology, v. 101, no. 6, p. $1275-1292$.

Young, L.E., 1989, Geology and genesis of the Red Dog deposit, western Brooks Range, Alaska: Canadian Institute of Mining and Metallurgy Bulletin, v. 82, p. 57-67

Zielinski, R.A., Bloch, Salman, and Walker, T.R., 1983, The mobility and distribution of heavy metals during the formation of first cycle red beds: Economic Geology, v. 78, no. 8, p. $1574-1589$. 
Publishing support provided by:

Denver Publishing Service Center, Denver, Colorado

For more information concerning this publication, contact:

Center Director, USGS Central Mineral and Environmental Resources Science Center

Box 25046, Mail Stop 973

Denver, CO 80225

(303) 236-1562

Or visit the Central Mineral and Environmental Resources Science Center Web site at:

http://minerals.usgs.gov/minerals/

This publication is available online at: http://dx.doi.org/10.3133/sir20105070N 



\section{$\frac{\mathbb{2}}{3}$}

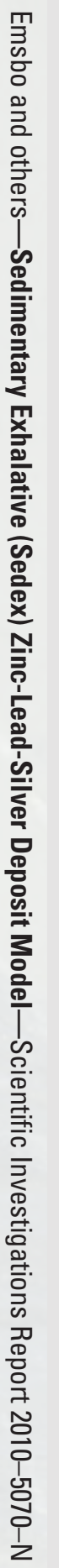

